UNIVERSIDADE DE SÃO PAULO

FACULDADE DE FILOSOFIA, LETRAS E CIÊNCIAS HUMANAS

DEPARTAMENTO DE LETRAS MODERNAS

ESTUDOS LINGÜÍSTICOS E LITERÁRIOS EM INGLÊS

Variante padrão de línguas imigrantes para falantes de dialeto na escola pública: incentivo ou ameaça à diversidade lingüística?

Candidato: Jordan Hahn Bandeira Orientador: Prof. Dr. Leland McCleary 
UNIVERSIDADE DE SÃO PAULO

FACULDADE DE FILOSOFIA, LETRAS E CIÊNCIAS HUMANAS

DEPARTAMENTO DE LETRAS MODERNAS

ESTUDOS LINGÜÍSTICOS E LITERÁRIOS EM INGLÊS

\title{
Variante padrão de línguas imigrantes para falantes de dialeto na escola pública: incentivo ou ameaça à diversidade lingüística?
}

Candidato: Jordan Hahn Bandeira Orientador: Prof. Dr. Leland McCleary

\begin{abstract}
Dissertação apresentada como prérequisito para a obtenção do título de Mestre no Programa de Pós-Graduação em Estudos Lingüísticos e Literários em Inglês da Faculdade de Filosofia, Letras e Ciências Humanas da Universidade de São Paulo.
\end{abstract}

São Paulo 
DEDICATÓRIA

A meus pais, Hayran (in memoriam) e Vera. 


\section{AGRADECIMENTOS}

Deixo aqui meus sinceros agradecimentos à Andréia Afonso, pelo apoio constante, pelas inúmeras leituras do texto e pela imprescindível colaboração na coleta das entrevistas que integram este trabalho; à Zilma Seidler, Mateus Fuck, Thamara Dorigon e Janete Müller, pelas entrevistas que gentilmente cederam; aos pais de Mateus Fuck e de Thamara Dorigon, que graciosamente autorizaram a participação de seus filhos; a Glauber Cunha, do CDI do Jornal Zero Hora de Porto Alegre, pelo auxílio com as referências provenientes daquele periódico; ao Professor François Grin, da Universidade de Genebra, pela gentileza de seu auxílio com relação ao texto do qual é co-autor; ao Professor Dr. José Carlos Sebe BomMeihy, Diretor do Núcleo de Estudos em História Oral da Universidade de São Paulo, pela introdução ao fascinante mundo da História Oral; à Professora Dra.Vera Paiva e ao Professor Dr. Arley Andriolo, do Instituto de Psicologia da Universidade de São Paulo, pela inestimável contribuição, referente a aspectos éticos e metodológicos, que busquei integrar a esta dissertação; ao Professor Dr. Lynn Mario T. Menezes de Souza, do Departamento de Letras Modernas da Faculdade de Filosofia, Letras e Ciências Humanas da Universidade de São Paulo, por sua participação na banca de meu exame de qualificação e pelo constante estímulo ao pensamento; à $\mathrm{Dr}^{\mathrm{a}}$. Suzana Lopes Salgado Ribeiro, também por sua participação na banca de meu exame de qualificação e pelas inestimáveis contribuições relativas aos elementos de História Oral incorporados a este trabalho.

Reservo um agradecimento especial ao Professor Dr. Leland Emmerson McCleary, do Departamento de Letras Modernas da Faculdade de Filosofia, Letras e Ciências Humanas da Universidade de São Paulo, a quem tive o privilégio de ter por orientador nesta jornada e a quem pertencem quaisquer méritos deste trabalho, cujas falhas e incorreções são todas de minha inteira responsabilidade.

São Paulo, 20 de dezembro de 2008. 
"Seja você a mudança que quer ver no mundo."

- Gandhi 


\section{RESUMO}

Esta dissertação faz considerações sobre a natureza da interferência derivada da introdução de variantes padrão de línguas imigrantes no currículo do sistema de escolas públicas de comunidades de falantes de dialetos. A pesquisa busca uma maior compreensão da questão por meio da análise de discurso e conteúdo encontrados em artigos de jornal, artigos disponíveis na Internet, mensagens trocadas em comunidades virtuais e quatro entrevistas colhidas de habitantes do município de Angelina em Santa Catarina, onde falantes de dialeto freqüentam escolas públicas onde o inglês é a única oferta de língua estrangeira, apesar da constituição étnica predominantemente germânica da população local. O trabalho ainda examina modelos teóricos de contato lingüístico baseados em teoria dos jogos em termos de sua relevância em um cenário mais complexo onde um dialeto coexista com sua variante padrão e uma língua nacional.

Palavras-chave: língua imigrante, língua minoritária, dialeto, diglossia, política lingüística 


\begin{abstract}
This dissertation prompts considerations about the nature of the interference deriving from the introduction of standard variants of immigrant languages into the curriculum of the public school system in communities of dialect speakers. The investigation seeks a greater understanding of the problem by means of discourse and content analysis of articles published in newspapers, articles available on the internet, forum posts, and four interviews collected from inhabitants of Angelina, a municipality in the State of Santa Catarina where dialect speakers attend public schools where English is the only foreign language option in spite of the predominantly German ethnic make-up of the local population. In addition, existing theoretical models that examine language contact from the perspective of game theory are examined in terms of their relevance in a more complex scenario where a dialect coexists with its corresponding standard variant and a national language.
\end{abstract}

Key words: heritage language, minority language, dialect, diglossia, language policy 
SUMÁRIO

Introdução......................................................................................... 10

Capítulo 1 - Quadro teórico ........................................................................ 18

Capítulo 2 - Metodologia ........................................................................................... 21

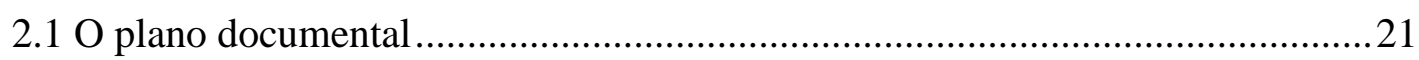

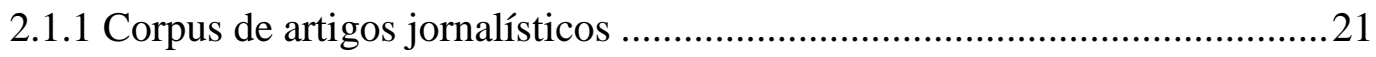

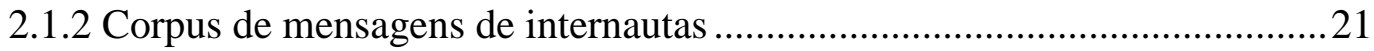

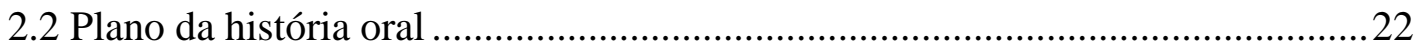

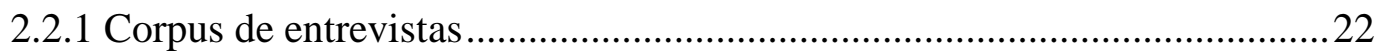

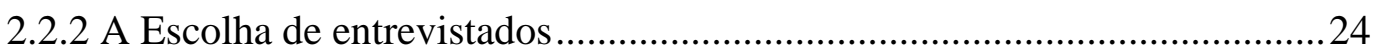

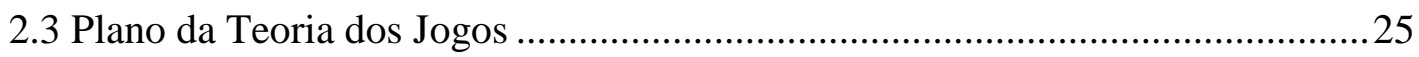

Capítulo 3 - Dialetos diante da variante padrão ..................................... 26

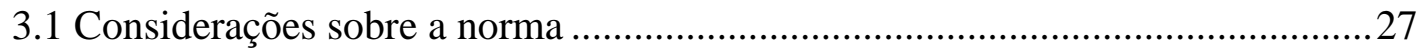

$3.2 \mathrm{O}$ indivíduo diante das forças linguísticas ...................................................... 30

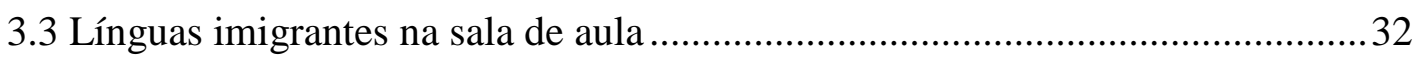

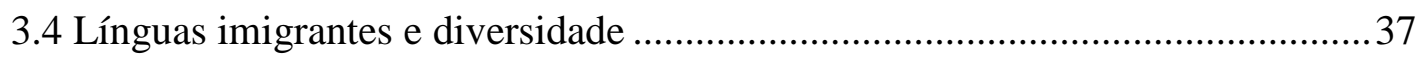

Capítulo 4 - Análise documental ............................................................... 40

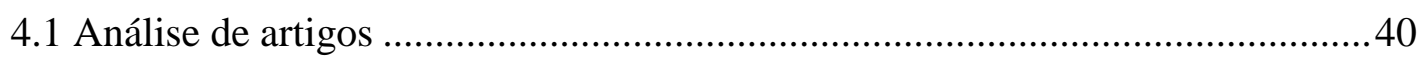

4.1.1 Resgate lingüístico-cultural ............................................................... 40

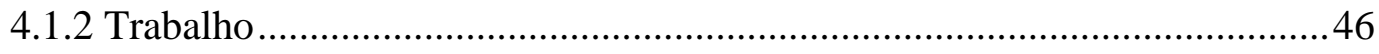

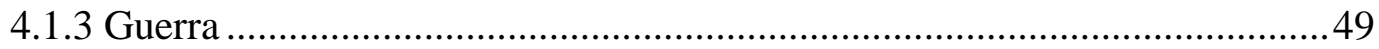

4.1.4 Assimilação e resistência...........................................................................56

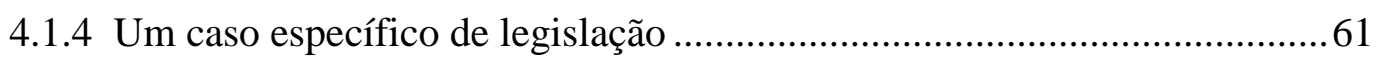

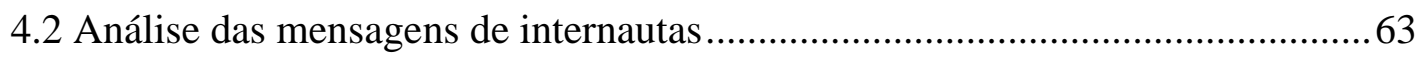

Capítulo 5 - Análise de entrevistas.......................................................68

5.1 Transcriação da entrevista com Zilma Seidler ..................................................68

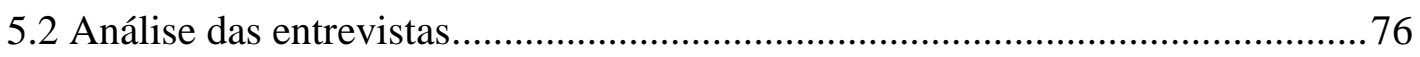

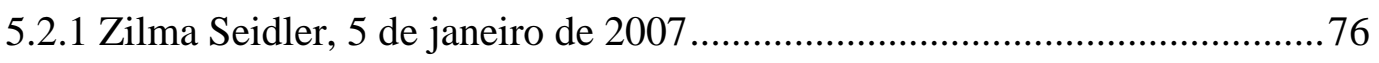

5.2.2 Mateus Fuck e Thamara Dorigon - 26 de Julho de 2007 ........................... 83

5.2.3 Janete Müller-26 de julho de 2007 ........................................................... 90 
5.2.4 Mateus Fuck e Janete Müller - 28 de julho de 2007. 94

Capítulo 6 - Centro e periferia ..............................................................................96

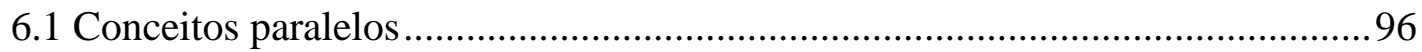

6.2 Línguas em competição no contexto globalizado............................................ 103

Capítulo 7 - Os Jogos de David Laitin ...................................................... 105

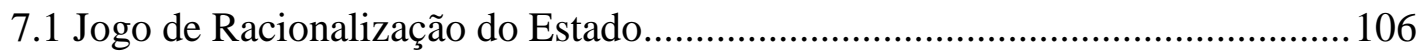

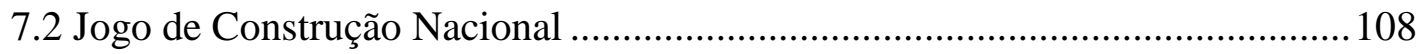

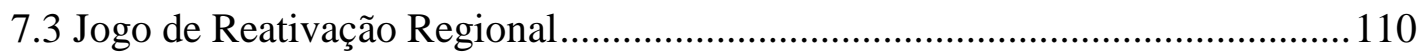

7.4 Jogo de Alteração Espontânea Regional ....................................................... 112

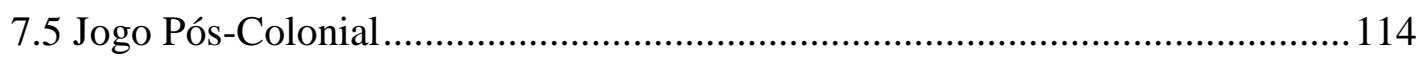

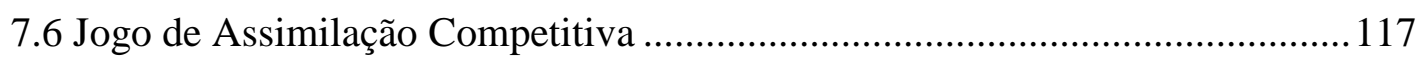

Capítulo 8 - Teoria dos jogos e dialeto ............................................................. 120

8.1 Participação na região versus participação global........................................... 120

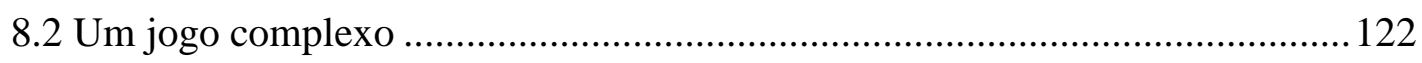

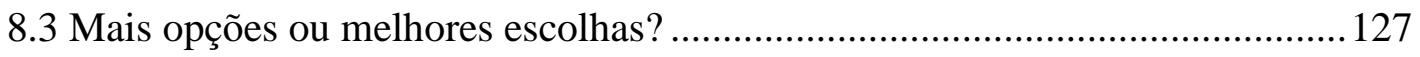

Capítulo 9 - Conclusões.......................................................................................... 129

9.1 Especificidades locais e consciência da diversidade ...................................... 129

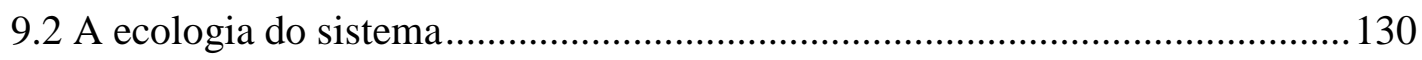

9.3 Um mundo de prêmios, riscos e preços ........................................................... 133

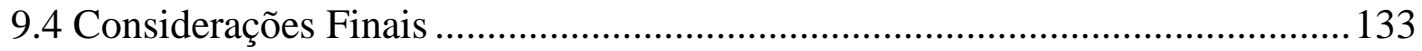

Referências .............................................................................................. 137

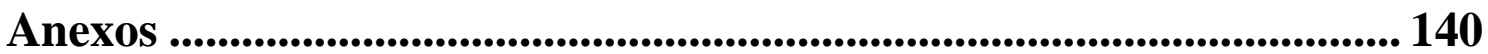

Anexo A - Autorizações para utilização de entrevistas ........................................ 141

Anexo B - Artigos do Jornal Zero Hora.............................................................. 142 


\section{INTRODUÇÃO}

\section{O percurso}

A intenção original deste trabalho era a de fazer um levantamento das políticas lingüísticas que afetam as línguas imigrantes em nosso país em moldes semelhantes aos propostos por Heinz Kloss em The American Bilingual Tradition (1997). A realidade da investigação inicial, todavia, apontou para a grande complexidade de um empreendimento dessa natureza. O percurso que pareceu lógico diante desse cenário foi o do estreitamento da pesquisa em torno de uma questão relativa às línguas imigrantes que tivesse relevância dentro do universo da pesquisa em sociolingüística.

A busca por essa questão relevante foi, em grande parte, influenciada pelo encontro com uma falante de dialeto alemão, Zilma Seidler, natural de Angelina, em Santa Catarina, cuja história de vida contribuiria para este trabalho na forma de depoimento. Foi nas falas de Zilma que encontramos o mundo diferente daqueles brasileiros que não têm o português como língua materna e percebemos a complexidade do contato entre uma língua imigrante e outras línguas ao seu redor.

A entrevista inicial de Zilma Seidler levaria posteriormente à pesquisa de artigos que integram o acervo do IPOL, Instituto de Investigação e Desenvolvimento em Política Lingüística, sediado em Santa Catarina, e à pesquisa de outras fontes, das quais destacamos o Jornal Zero Hora de Porto Alegre. A análise inicial desses artigos apontaria para contradições e ambivalências em torno da questão da oferta de variantes padrão de línguas imigrantes para comunidades de descendentes de imigrantes. Essa análise ainda revelaria a tendência de disseminação de políticas públicas para a inclusão dessas variantes padrão nos currículos escolares das comunidades imigrantes no sul do país.

É neste ponto que se materializa a questão da investigação da sobreposição da variante padrão sobre os dialetos das comunidades imigrantes como questão central de nosso trabalho e passaríamos à busca de novas fontes que pudessem auxiliar na compreensão do possível impacto das políticas que vem sendo implantadas nos estados do Sul do Brasil.

A questão da sobreposição da variante padrão sobre uma forma dialetal é extremamente complexa. Tal complexidade é agravada ainda mais pela necessidade, tanto ao longo deste trabalho, como na realidade das políticas públicas, de generalizações sobre línguas imigrantes, dialetos imigrantes e mesmo sobre o que venha a constituir a variante padrão, já que existe um amplo espectro do que possa ser compreendido dentro de cada um desses conceitos. 
Em termos práticos a variante padrão, para efeito de nosso estudo, será a variante percebida como padrão pelo sistema educacional e será o dialeto aquilo que é percebido, pela comunidade de falantes, como sendo partilhado pela comunidade, mas que difere da variante ensinada na escola.

O dialeto alemão será tomado como exemplo principal para o aprofundamento da questão por diversos motivos que incluem a disponibilidade de um colaborador inicial, falante desse dialeto, e a existência de um contexto de grande complexidade histórica e social. Tal escolha pelo dialeto alemão como protagonista principal não excluirá referências a outros contatos lingüísticos, já que existe o contato de várias línguas imigrantes mesmo dentro de contextos geográficos pequenos e isolados onde isso possa não ser, de imediato, percebido e tendo-se em mente que as políticas públicas, como já dito, são freqüentemente baseadas na generalização inerente à natureza daquilo que pertence à esfera do público e não à esfera do indivíduo.

Para a organização deste trabalho, foram determinados dois momentos distintos: um de análise de dados coletados e outro de análise de modelos teóricos. Na parte inicial dedicada à análise dos dados, o trabalho proposto será desenvolvido em três planos distintos, a começar pela análise do corpus constituído de artigos, independentemente de sua proveniência, que foram reunidos com base em seu conteúdo, por tratarem de forma direta ou indireta da questão da existência dos dialetos. Em um segundo momento, a análise foi dirigida às mensagens trocadas por Internautas. Finalmente, ainda na parte de análise de dados, chegaremos às entrevistas que contaram com um capítulo próprio. É ainda importante salientar que, devido ao freqüente cruzamento de informações, essas divisões são apenas indicativas do foco principal, podendo conter sobreposições ocasionais entre as fontes trabalhadas.

Feita a análise do que parece ser a visão coletiva propagada pelos meios de informação e tendo-se ouvido os depoimentos de indivíduos próximos à questão do dialeto, foi necessário buscar um modelo clássico para a compreensão das situações de multilingüismo e encontramos na Teoria dos Jogos e, particularmente, nos modelos propostos por David Laitin (1988 e 1993), subsídios para novas reflexões e a possibilidade de que talvez, por análise de seus modelos, pudéssemos compreender os cenários complexos de contato entre dialeto, variante padrão, língua do Estado e língua estrangeira em um mundo globalizado, onde a variante padrão correspondente ao dialeto pode entrar em competição com uma língua franca útil ao funcionamento desse mundo globalizado. 
Se no mundo pós-moderno a questão central do teórico político diante das escolhas da sociedade é "E qual o mal nisso?", como nos lembra Ronald Schmidt, Sr (2006, p.96), a realidade inerente a tal pergunta reside no fato de ainda tratar-se de uma pergunta e não, simplesmente, de uma autorização implícita para o que ali possa estar envolvido.

A realidade do funcionamento do mundo e do Estado está ligado a fatores concretos como custos e recursos, sendo que estes não provem uniformemente de todos os elementos que integram a sociedade, permitindo que as escolhas de alguns tenham, na prática, impacto sobre outros.

Também dentro dessa abordagem matemática encontramos uma correlação com os conceitos de "centro" e "periferia", que remetem à uma reflexão sobre as formas de hierarquização nas sociedades humanas e sobre como tais hierarquias podem ser redefinidas de forma sutil e não necessariamente visível.

\section{O mapa e o território}

Para que possamos compreender melhor este trabalho é necessário discutir-se a geografia aqui envolvida. Afinal, temos um estudo sobre dialetos que se sustenta em grande parte sobre o dialeto de uma localidade em Santa Catarina ao mesmo tempo em que são citados artigos, sobretudo, publicados no Rio Grande do Sul. Para que se compreenda isso é necessário compreender dois fatores que, apesar de distintos, estão intimamente relacionados.

O primeiro desses fatores é que estamos condicionados a pensar a nossa geografia pelo filtro geopolítico do Estado Nacional com as respectivas divisões de estados e municípios. Quando tratamos de questões imigrantes e lingüísticas, é necessário compreender que os contingentes imigrantes transcendem a geografia dos mapas e se espalham por áreas de difícil definição. Em consequiência, a política que agora é criada em uma localidade poderá servir de modelo para uma futura política em outra comunidade que, embora, aparentemente desconexa em termos geográficos, possui vínculos étnicos, culturais e identitários com a primeira.

Com o auxílio de nossa primeira entrevistada, localizamos Angelina, uma localidade particularmente interessante para este estudo por duas razões essenciais: sua existência no contex to de uma rede de localidades unidas por vínculos étnicos, lingüísticos e culturais e sua proximidade a centros cujas políticas lingüísticas para línguas minoritárias, mais especificamente Blumenau, poderão vir a influir no destino dos seus falantes de dialeto. 


\section{Angelina}

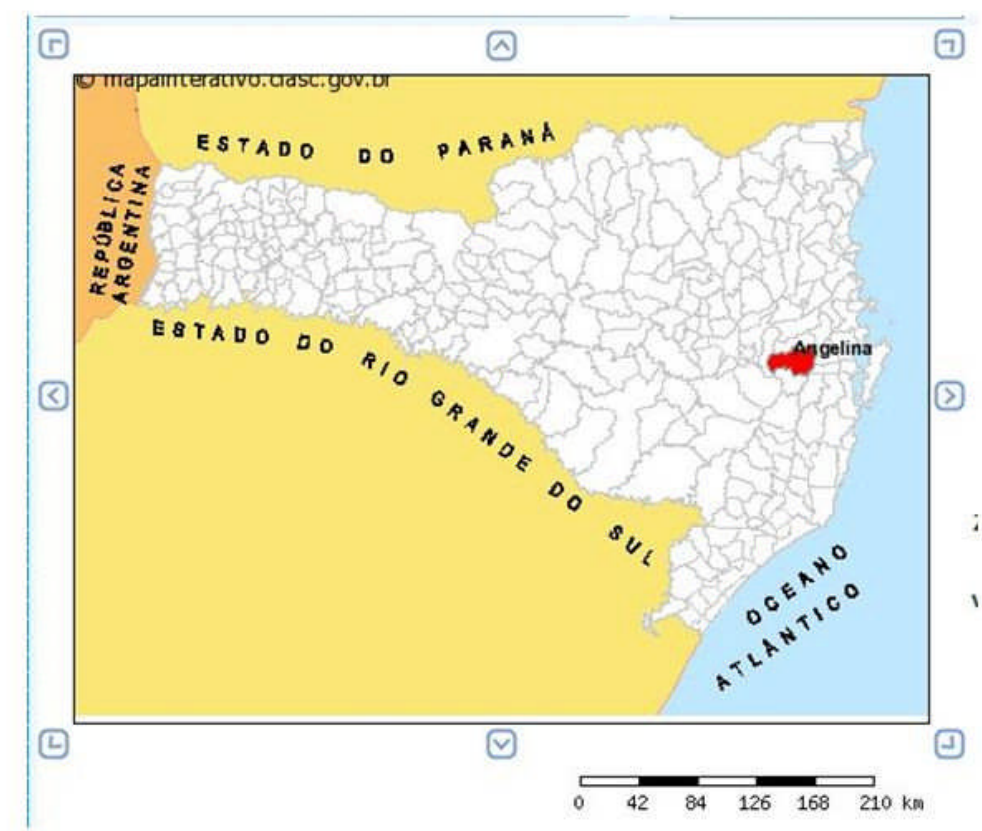

http://www.mapainterativo.ciasc.gov.br/sc.phtml

Figure 1 - Localização de Angelina

Localizada a 70 km de Florianópolis, Angelina surge, de acordo com a versão oficial do governo do estado (SANTA CATARINA, 2008), em 1858 com os primeiros imigrantes alemães, vindos das colônias vizinhas de Sacramento e São Pedro de Alcântara, que se estabeleceram na localidade que chamaram de Vila Mundéus. Em 1891, a localidade torna-se distrito do município de São José e recebe o nome de Angelina, em homenagem a Ângelo Muniz da Silva Ferraz, então presidente do Conselho de Ministros do Rio de Janeiro. Angelina só adquire estatuto de município em 1961.

De acordo com dados do governo de Santa Catarina, a base econômica é a agricultura e a população do município é de 5412 habitantes. Ainda segundo o governo do estado de Santa Catarina, a localidade é descrita como de colonização e etnia alemãs.

É somente diante da distribuição étnica ou lingüística da região como um todo que podemos começar a compreender a complexidade das conexões que não cabem em mapas convencionais. Mais do que regiões circunscritas, temos de lidar com redes de conexões, eixos e ramificações onde indivíduos podem ter mais em comum com outros indivíduos separados por várias fronteiras estaduais do que com seus próprios vizinhos. 
Em nosso caso específico, o Rio Grande do Sul tem grande importância, por ter sido um pioneiro no incentivo à inclusão de línguas imigrantes, e, mesmo aqui, já incorremos os problemas impostos pela projeção de fronteiras imaginárias sobre o mapa da realidade, já que a maioria dessas iniciativas teve origem em municípios como Venâncio Aires, por exemplo, e não são necessariamente provenientes da esfera do estado, embora possam contar com o aval do mesmo.

O mapa abaixo, extraído do Atlas Etnográfico da Região Sul (KOCH, W; KLASSMAN, M.S.; ALTENHOFEN, C. V., 2002) mostra a sobreposição de camadas mencionada acima e atesta a complexidade do cenário etnográfico de uma região que recebeu contingentes europeus que se distribuíram, ao longo de gerações, por uma ampla extensão do território brasileiro, mantendo e nutrindo, no entanto, valores e modo de vida baseados em suas origens européias e que os unificam no plano identitário.

\section{Etnografia da Região Sul do Brasil}

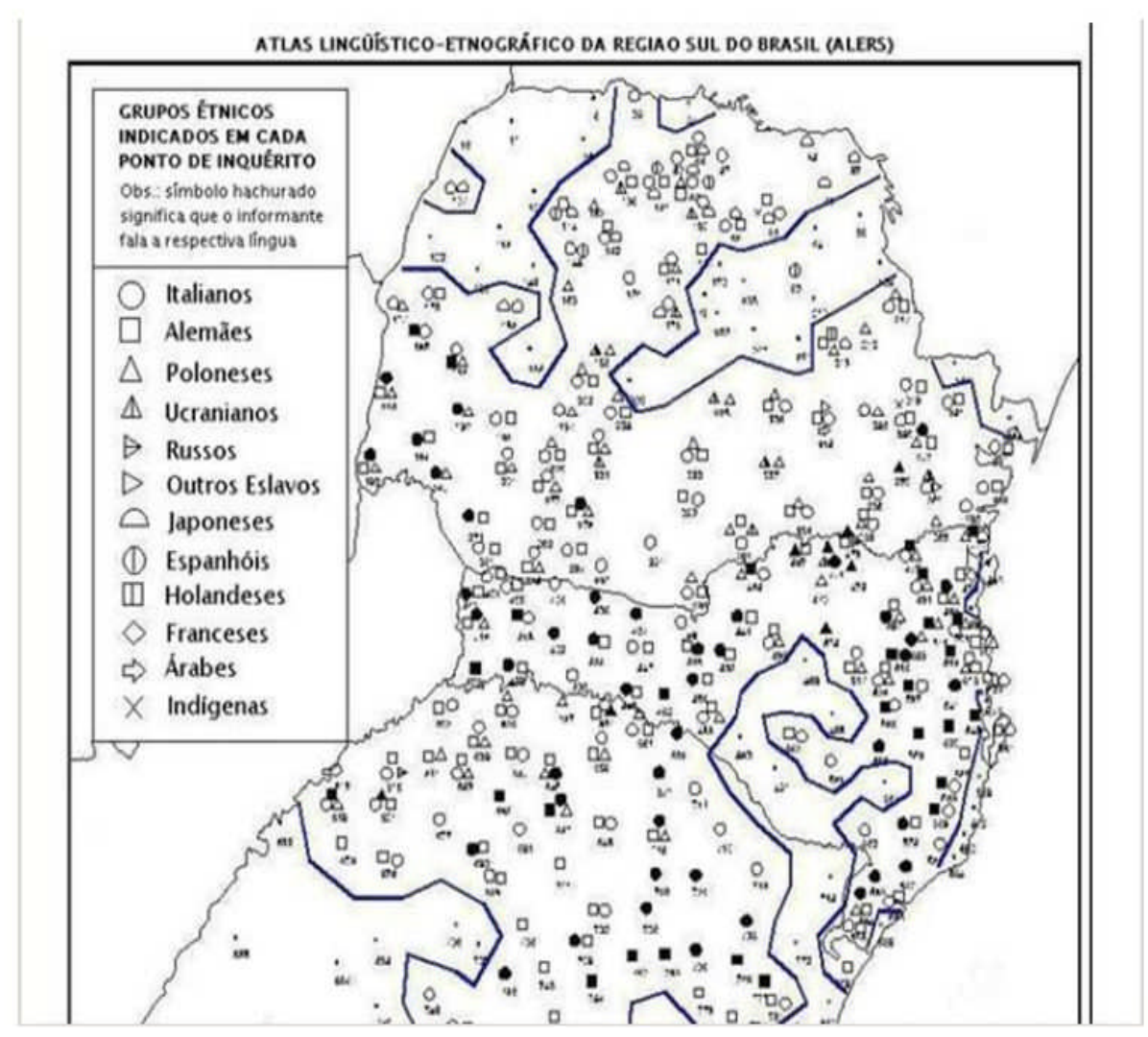

Figure 2 - Distribuição Étnica na Região Sul 
É exatamente tal conexão no plano identitário que abre espaço para a promoção de políticas lingüísticas abrangentes. E embora tais políticas possam surgir em função da percepção de unidade de um grupo imediato, é improvável que tais iniciativas não se espalhem pela rede que conecta o grupo no qual se inserem. Isso pode ser verificado no caso das políticas iniciadas no Rio Grande do Sul, onde iniciativas se espalharam de município em município.

Embora exista um consenso praticamente universal sobre a necessidade da existência de políticas lingüísticas voltadas ao tratamento dos cenários multilíngües, a realidade desses cenários ainda impõe vários questionamentos. Como aponta Schmidt, Sr. (2006, p. 96), “os teóricos políticos estão mais centralmente preocupados, de forma mais semelhante à dos humanistas, com questões de "significação" e "significado" do que com causa e efeito. Nossas políticas linguiísticas, todavia, são, como todos os atos humanos, derivadas de suas causas e trarão consigo, sejam positivos ou negativos, os seus efeitos.

\section{Uma terminologia}

Para que se prossiga na exploração dessas questões é preciso, antes de mais nada, estabelecer-se os significado dos termos que utilizaremos ao longo de texto.

Primeiramente, faz-se necessário o estabelecimento de uma distinção entre os conceitos de "língua estrangeira" e de "língua imigrante". Tais termos, apesar de imprescindíveis para a compreensão da questão do multilingüismo, parecem, por vezes, ignorados pela prescrição, como é visível em pareceres do Conselho Nacional de Educação (CNE, 1998), nos quais são encontrados os conceitos de "língua materna", de "língua estrangeira" e de "língua migrante", sem que os mesmos sejam definidos com clareza.

Para efeito deste trabalho, utilizaremos as seguintes definições:

O termo "língua materna" será utilizado para definir a primeira língua aprendida pelo indivíduo, por meio de seu convívio familiar.

O termo "língua estrangeira" será utilizado, em linhas gerais, para definir toda e qualquer língua, que não a língua portuguesa, ensinada nas escolas, tanto em caráter formativo como instrumental e tal língua estrangeira corresponderá à variante padrão desse idioma. É importante acrescentar, contudo, que, em determinados momentos, o termo referese à língua que é estrangeira para o indivíduo.

Utilizaremos ainda o termo "língua imigrante", correspondendo ao termo inglês heritage language, nos termos propostos por Gambhir (2001, p.212), para definir uma língua 
com a qual o falante tenha vínculo cultural, ainda que não seja essa necessariamente sua língua materna.

Faz-se ainda necessário estabelecer-se uma distinção entre o termo "língua imigrante" e o termo "língua migrante", utilizado este último em parte de nossa legislação, mas que pode referir-se também ao contato de variantes do português, no evento de migrações internas, como é visível em Cury (2007).

Também se faz necessário definir "dialeto" e "variante padrão" para os fins deste trabalho. O termo "dialeto" é aqui utilizado para referir-se a uma forma lingüística minoritária, geralmente oral. É importante salientar que não parece existir um consenso teórico sobre o que constitui um dialeto, ficando tal definição freqüentemente subordinada a questões identitárias. Embora freqüentemente associado à questão da mútua compreensão. Há línguas distintas que são compreensíveis entre si, como Português e Espanhol e dialetos de uma mesma língua que não são compreensíveis entre si (total ou parcialmente), como é o caso do Português e do Português da Galícia, ou Galego. É importante lembrar ainda que "mútuo" aqui não significa a existência de uma reciprocidade exata e que um falante pode ter um grau de compreensão maior da língua do outro.

O trecho abaixo, em Português Galego (PORTAL GALEGO DA LÍNGUA, 2009), demonstra para o leitor, o problema da compreensão parcial, semelhante ao que ocorre entre o alemão padrão e a o dialeto falado em Angelina.

PGL - A 24 de Fevereiro de 2009 reuniram na cidade de Lugo um colectivo de pessoas de diversos campos, numha iniciativa criada a partir da Mesa Pola Normalización Lingüística, para participar na cavalgata de entrudo da cidade amuralhada cumha comparsa baptizada como «Lapidamente». (PORTAL GALEGO DA LÍNGUA, 2009)

Embora, seja fácil entender o início da frase e possamos nos empenhar para entender o trecho grifado, a compreensão do dialeto não é automática e apresenta problemas para a decodificação da mensagem. Apesar dessa ininteligibilidade, estamos diante de dialetos da mesma língua.

O termo "variante padrão", em contrapartida, representa uma variante de língua estrangeira, percebida como correspondente ao dialeto, em função de uma percepção sobre uma mesma origem geográfica para ambos, além de um caráter oficial para o primeiro. Ou seja, tomando-se o caso do dialeto alemão, por exemplo, por serem tanto o dialeto quanto o alemão padrão originários da Alemanha e por ser o alemão padrão a língua oficial da Alemanha, passa a ser o alemão padrão a contraparte do dialeto alemão aqui examinado. 
Caberia ainda aqui lembrar que, ainda hoje, na Alemanha são reconhecidos, segundo a Deutsche Welle (2009), nove dialetos mais importantes: o alsaciano, o bávaro, o berlinense, o alemânico, o hamburguês, o dialeto de Hessen, o kölsch, o baixo-alemão, o suábio e o saxônio, dialeto para o qual Lutero originalmente traduziu a Bíblia e que é hoje um dos mais rejeitados pelos alemães. Curiosamente, ainda segundo a mesma fonte, alguns dialetos passam por um momento de ressurgimento na Alemanha, ficando a cargo do berlinense um maior grau de ruptura com as declinações e regras gramaticais.

É importante ainda lembrar que o termo "variante padrão" não está aqui sendo utilizado como sinônimo de "variante culta" já que este termo implica conotações que julgamos não pertencentes a este trabalho. É ainda mais importante lembrar que, embora variante culta e variante padrão não tenham para nós o mesmo significado, que tal distinção nem sempre é mantida pelos autores aqui citados, e que, portanto, dentro do contexto de determinadas citações, os termos deverão ser compreendidos como equivalentes.

Também faz-se necessário compreender que muitas vezes certos conceitos estarão sobrepostos, de acordo com cada indivíduo, e que a variante padrão poderá, em muitos casos, corresponder, legitimamente, à língua imigrante, mesmo quando o falante tenha com ela apenas um vínculo cultural e nem mesmo a fale, desde que tenha sido esta a variante trazida por seus ancestrais.

Em Gambhir (2001, p.215), encontramos ainda mais uma classificação útil quando apresenta o conceito de Língua Ensinada Mais Raramente (Less Commonly Taught Languages), já que a idéia do ensino de uma língua imigrante também intersecta um esforço de incentivo à oferta de línguas não oferecidas normalmente. A relevância dessa última distinção ficando por conta da possível heterogeneidade das comunidades alvo, nas quais a língua imigrante, representada pela variante padrão poderá ser tanto língua imigrante para uns quanto língua que era, até então, pouco ofertada para outros. 


\section{CAPÍTULO 1 - QUADRO TEÓRICO}

Do ponto de vista teórico, o ponto de partida deste trabalho é o mapeamento sobre o multilingüismo nos Estados Unidos que Kloss (1993) apresenta em The American Bilingual Tradition. Em sua obra, Kloss (1993) oferece um minucioso levantamento do contexto multilíngüe norte-americano em relação às políticas de tolerância e de promoção de línguas minoritárias e examina as implicações das atitudes lingüísticas sobre o destino das políticas para essas línguas.

Partindo dessa idéia inicial de mapeamento, diferentes autores contribuiriam para a compreensão de inúmeros aspectos que emprestam complexidade à questão do incentivo ou da interferência sobre uma língua imigrante.

Kaufman (2005) agrega contribuições imprescindíveis sobre a mudança da língua (language shift), ou seja, o fenômeno da gradual troca da língua materna minoritária pela língua utilizada pela maioria, além de esclarecer, por extensão, a reflexão sobre a possibilidade de reversão dessa tendência.

Cummins (2000), por sua vez, ressalta a importância da língua materna na educação de crianças bilíngües, fato de especial relevância se levarmos em conta o fato de ser o dialeto a língua materna de muitas comunidades imigrantes no sul do país. Ainda com relação ao dialeto, é importante ressaltar o trabalho de Altenhofen (2004) pelo reconhecimento da autonomia que existe na questão dos dialetos alemães do sul do país. Isso significa que o dialeto Hunsrückisch, por exemplo, não deve ser percebido apenas como uma versão inculta, correspondente a um alemão padrão.

Gambhir (2001) também é fundamental para o nosso quadro teórico, pois é a partir dele que estabelecemos a importância do vínculo cultural e identitário entre o falante e sua língua materna - uma consideração extremamente importante no caso dos dialetos já que estes são, com frequiência, línguas maternas. Em nosso contexto específico de estudo, os dialetos existem vivos em meio a contextos onde se propõe uma reativação linguiística com base no ensino uma variante padrão que, embora possa ser reconhecida como língua imigrante, devido ao vínculo étnico e cultural com os habitantes, atingiria os aprendizes de formas diversas em função da língua ou línguas que tragam de casa.

Não poderíamos falar do aparato teórico desta dissertação sem fazer menção a Derrida (1993) e suas considerações sobre centro e periferia, fundamentais para o estabelecimento de 
nosso raciocínio, já que esses conceitos encontram paralelo nos conceitos de Poder Central e de Elite Regional vistos em Laitin (1988 e 1993) e que serviriam de base para uma análise de dados à luz da Teoria dos Jogos.

Ainda sobre o aparato teórico é importante perceber-se que vários dos textos utilizados não são recentes e sua presença é justificada na medida em que são frutos de contextos históricos relevantes para nossa discussão e que podem auxiliar na compreensão de nosso contexto. Afinal, não parece mera coincidência o fato dos textos de Laitin aqui utilizados, Language Games (1988) e The Game Theory of Language Regimes (1993), terem sido escritos em um período que coincide com o do rápido desmantelamento da antiga União Soviética, quando grupos étnicos se organizam para constituir novas nações em um processo paralelo ao processo de construção nacional descrito por Laitin.

Além de sua relevância contextual, os artigos de Laitin são extremamente valiosos por trazerem a Teoria dos Jogos para o mundo do contato lingüístico. É nos seus modelos que encontramos a possibilidade para uma desconstrução racional, ainda que freqüentemente radical, da questão do contato entre duas línguas. Por extensão, esperamos poder transportar elementos dos modelos de Laitin para a realidade lingüística que inclui dialetos.

Os modelos de Laitin, por sua vez, contemplam elementos de cunho econômico que exigem melhor compreensão. Tal compreensão foi encontrada na sistematização proposta pelos economistas Grin e Vaillancourt, autores de The Economics of Multilingualism: Overview and Analytical Framework (1997). Em seu trabalho, Grin e Vaillancourt (1997, p. 50) exploram a relação de custo e benefício em contextos de multilingüismo diante da relevância de fatores sociais, privados e não privados de mercado.

Tanto a Teoria dos Jogos como a abordagem econômica de Grin e Vaillancourt pressupõem o conceito de "equilíbrio", como ponto em torno do qual um sistema se estabiliza. Um conceito que, por sua vez reforça nossa preocupação com um "equilíbrio" de várias dimensões e cujas implicações ecológicas são aqui investigadas, sobretudo, com o auxílio de Hornberger (2002), para quem sistemas lingüísticos possuem paralelos com ecossistemas.

Devido à presença de elementos de História Oral, cuja metodologia foi adotada para o trabalho de campo, não poderíamos deixar de citar o trabalho do Prof. Dr. José Carlos Sebe Bom Meihy, cujo Manual de História Oral (2005) serviu como referência para a coleta de colaborações e do qual emprestamos o conceito de "transcriação" que, para efeito de nosso estudo, pode ser entendido como uma versão da entrevista que mantém o conteúdo original 
em um formato de mais fácil leitura. Os formulários de autorização utilizados para a coleta de dados são também adaptações das sugestões encontradas nessa obra.

Compreender uma situação lingüística, no entanto, também remete à compreensão de fatores sociais e históricos específicos ao contexto estudado e é trabalho de Fáveri (2005), sobre a fricção entre o contingente "imigrante" e o seu entorno, termo que descreve não apenas o imigrante propriamente dito, mas também freqüentemente seus descendentes, e o que viríamos a chamar, ao longo deste texto, por imposição da correlação com o modelo de David Laitin, de Poder Central.

Nesta breve revisão, buscamos salientar apenas as obras, os autores e os raciocínios mais influentes na reflexão contida na versão final deste trabalho. 


\section{Capítulo 2 - Metodologia}

Com relação à metodologia, este estudo buscará uma maior compreensão da questão da interferência sobre o dialeto por meio de uma análise que ocorrerá em três planos: um plano documental, um plano de história oral, colhida em uma comunidade multilíngüe em contato com um dialeto específico, e um plano matemático, pela perspectiva da Teoria dos Jogos na resolução de conflitos.

\subsection{0 plano documental}

O Plano documental será constituído, por sua vez, de dois desdobramentos: o primeiro com base em artigos jornalísticos provenientes de diversas fontes e o segundo com base em mensagens de internautas discutindo a questão do dialeto.

\subsubsection{Corpus de artigos jornalísticos}

A primeira fonte de dados levantados se constitui de um corpus de artigos jornalísticos pertinentes ao assunto, alguns publicados pelo Jornal Zero Hora de Porto Alegre sobre a situação no Rio Grande do Sul, os quais se encontram na íntegra no Anexo G, outros veiculados diretamente por meio da Internet ou disponíveis por meio da base de dados do IPOL - Instituto de Investigação e Desenvolvimento em Política Lingüística, com sede no Estado de Santa Catarina, cujos trechos relevantes para nossa discussão aparecem transcritos em diferentes partes desse trabalho.

\subsubsection{Corpus de mensagens de internautas}

A realidade contemporânea não pode esquivar-se da existência da pesquisa com auxílio da Internet. Em nosso trabalho, foram utilizados diversos recursos, incluindo a pesquisa de discussões relevantes ao tema que aparecem representadas ao longo da primeira parte deste trabalho na forma de mensagens que muito revelam sobre as percepções e atitudes do indivíduo comum sobre a língua imigrante e o dialeto, sejam corretas ou não, no sul do país. As mensagens foram localizados à partir de chaves de busca incluindo os termos “dialeto", “dialeto alemão" e "Hunsrückisch". É importante ainda lembrar que essas mensagens não têm origem acadêmica e foram trocadas no decorrer de discussões sobre áreas de colonização alemã. 


\subsection{Plano da história oral}

No plano da história oral, serão analisadas 4 entrevistas colhidas a partir de um roteiro temático. A partir da questão central da dissertação, ou seja, se a oferta da variante padrão a uma população falante de dialeto significa um incentivo ou uma ameaça à diversidade lingüística, destacamos alguns temas sobre os quais desejávamos saber a percepção dos entrevistados. Por meio das perguntas formuladas, buscamos saber as impressões dos entrevistados sobre: estar o entrevistado ciente ou não da existência de um dialeto local; o ensino de alemão na escola; a relação da língua alemã com a vida da comunidade em várias expressões; a noção de prioridade com relação ao ensino do alemão como língua estrangeira em comparação com o ensino do inglês como língua estrangeira; a atitude da comunidade com relação aos falantes de dialeto, de alemão padrão (Hochdeutsch) e de português; os canais de expressão do dialeto na vida da comunidade; a utilidade da língua alemã, do dialeto, e do inglês; a eficácia do ensino de língua estrangeira na escola; fatores que promovam language shift (por exemplo, o casamento com indivíduos de fora da comunidade).

Em virtude das prioridades para questões lingüísticas, foi adotado o modelo de história oral temática proposto por Meihy (2005, p.162) com a consciência de que as entrevistas não teriam focos necessariamente idênticos para todos os entrevistados, permitindo-se assim o grau de abertura necessário para que cada um trouxesse suas contribuições e preocupações mais significativas.

O modelo de autorização utilizado, o qual se encontra no Anexo A, é baseado nos modelos propostos por Meihy (2005, pp.212-217), tendo sido adaptado para integrar as transcrições e gravações a serem arquivadas. Um segundo modelo desse formulário foi criado e adaptado para ser assinado pelos pais ou responsáveis, no caso de entrevistados menores de idade. Todas as assinaturas coletadas, inclusive as assinaturas dos menores e de seus pais ou responsáveis, foram reconhecidas em cartório.

\subsubsection{Corpus de entrevistas}

Muito do direcionamento deste projeto se deve ao que foi coletado em nossa primeira entrevista com Zilma Seidler, entrevista que decorreu de um primeiro contato, no qual tomamos conhecimento de sua origem e do fato de Zilma Seidler ser falante de dialeto alemão. Em função da relevância de sua entrevista para o desenvolvimento deste projeto, incluímos uma transcriação da mesma, como proposta em Meihy (2005, p.195) com a intenção de facilitar ao leitor a compreensão das questões abordadas nesse depoimento. Para 
Meihy (2005, p. 195), “existem diferenças entre uma situação (língua falada) e outra (língua escrita)", acrescentando que "o mais importante na transposição de um discurso para o outro é o sentido, que, por sua vez, implica intervenção".

Muito embora tal intervenção seja útil para que o leitor depreenda o sentido do que é aqui importante, foi escolhida a manutenção da simples transcrição para os trechos que suportam a análise da entrevista.

A partir dessa entrevista inicial, julgamos necessária a inclusão de novas entrevistas que, assim como a primeira, serão analisadas quanto ao conteúdo e discurso. As entrevistas adicionais não foram transcriadas, tendo sido apenas transcritas parcialmente para a análise dos pontos de nosso interesse.

As transcrições parciais, tanto da entrevista inicial quanto das entrevistas adicionais, encontram-se distribuídas ao longo do capítulo referente a sua análise.

As três entrevistas subseqüentes foram coletadas no município de Angelina, onde nasceu à primeira entrevistada, escolha que julgamos pudesse ser útil para esclarecer algumas questões, já que o município inclui um grande contingente de falantes de dialeto e ainda não foi atingido por políticas lingüísticas que possam com ele interferir.

Com relação ao número de entrevistas, salientamos que as mesmas foram coletadas por uma perspectiva de história oral, cujo interesse se concentra na escuta do indivíduo e não estritamente no uso de entrevistas para coleta de dados quantitativos.

Nossa intenção sendo a de que servissem essas entrevistas como levantamento, em um primeiro momento, dos anseios e preocupações dos membros dessas comunidades com relação ao seu futuro lingüístico e, possivelmente estabelecer, por meio de reflexão sobre as contribuições dos colaboradores, parâmetros que permitam o desenvolvimento de futuros instrumentos de pesquisa. Dessa forma, situamos o corpus obtido em um território entre o estudo de caso clássico e o estudo qualitativo propriamente dito, buscando a conscientização sobre a dimensão humana individual que, freqüentemente, escapa à visão da tecnocracia preocupada com as soluções de caráter universal.

This must be done in a participative manner. By this I mean that writings must not themselves, paradoxically, reproduce the alienating technocracy which for many, as we have asserted, surrounds the subject matter itself. It is for this reason that this book is constructed as it is, following a cycle of awareness through knowledge and critical discussion, to individual and social action. (TOLLEFSON, 1991, p. vii) ${ }^{1}$

\footnotetext{
${ }^{1}$ Do prefácio de Christopher N. Candlin
} 
Ainda com relação à representatividade da amostra, é importante salientar que existe uma movimentação no campo da sociolingüística, por parte de estudiosos como Tollefson, na direção do estudo qualitativo e dos estudos de caso.

In addition, Tollefson advocates for a change in research methodology and the way the social scientist is perceived. He proposes a more qualitative research methodology, which is represented in his own case study approach. Whereas applied linguists have tended to ignore the human side of language, the individual case studies of language choices powerfully illustrate the impact of policy on people's lives and the contribution qualitative research can make to the field of language policy (de JONG, 1994).

Para que possamos compreender essa posição com maior clareza, bastaria a compreensão de um cenário em que quatro entrevistados expressassem diferentes visões sobre uma mesma questão; sendo a existência dessa diversidade exatamente o que se deseja apontar. A questão da língua imigrante, como muitas outras questões sociais contemporâneas, afinal, só ganha dimensão por conta de um movimento na direção da diversidade até aqui ignorada, em decorrência de uma posição periférica, cujo resgate verdadeiro só pode ocorrer quando o olhar se desloca para o grupo pequeno e o indivíduo, ao invés de deslocar-se para as maiorias.

Por meio desse entendimento, podemos depreender dessas entrevistas que não existe consenso sobre a questão do dialeto diante da variante padrão e que certos posicionamentos lingüísticos podem ser ofuscados se não prestarmos atenção ao indivíduo.

\subsubsection{A Escolha de entrevistados}

A seleção dos demais entrevistados se deu por meio do preenchimento de um sistema simples de quadrantes, estabelecido após a primeira entrevista, em que o universo dos Angelinenses seria inicialmente dividido entre urbano e rural e, subseqüentemente, dividido entre falantes e não-falantes de alemão ou dialeto (partindo-se do pressuposto de que na localidade há também falantes de Hochdeutsch, ou alemão padrão).

Dentro desse quadro inicial, estabelecemos como objetivo entrevistar, além do colaborador inicial, especialmente, adolescentes, alunos no sistema público de ensino do município de Angelina, e que tivessem diferentes vínculos com o dialeto ou com a língua alemã, tendo sido esses vínculos determinados previamente por meio de referências de outros moradores que nos auxiliaram a localizar os entrevistados. 


\section{Tabela 1}

\begin{tabular}{l|c|c}
\hline & Originários da área urbana & Originários da área rural \\
\hline Falantes de alemão/dialeto & & Colaborador 1 \\
& & Colaborador 4 \\
\hline Não-falantes de alemão/dialeto & Colaborador 2 \\
& Colaborador 3 & \\
\hline
\end{tabular}

\subsection{Plano da Teoria dos Jogos}

Ainda que o mundo da pós-modernidade, representado por seus teóricos esteja mais preocupado com a questão da "significação" e do "significado"2 (SCHMIDT, Sr., p.96), não podemos deixar de nos perguntar o que as abordagens clássicas, ou mesmo estruturalistas, podem contribuir para a compreensão de questões atuais complexas.

Ignorar a importância dessa contribuição seria invalidar toda a trajetória da evolução do pensamento humano, em prol de uma espécie de fatalismo, onde o ser humano é incapaz de utilizar a razão para antever as consequiências de seus atos. Tal negação de nossa herança intelectual seria extrema, ao mesmo tempo em que se oporia a tendências, em diversas áreas do conhecimento, onde o valor da modelagem teórica e inegável.

Com isso em mente, partimos para a compreensão de modelos encontrados na Teoria dos Jogos (LAITIN, 1988) com o intuito de avaliar a aplicabilidade de modelos desenvolvidos para cenários de contato entre duas línguas em cenários mais complexos que incluem os dialetos.

\footnotetext{
${ }^{2}$ No original: significance and meaning
} 


\section{CAPÍTULO 3 - DiALETOS DIANTE DA VARIANTE PADRÃO}

Ao longo das últimas décadas, surgiram, sobretudo nos estados do sul do Brasil, várias iniciativas de ensino de línguas européias por meio de sua inserção, sob a forma de língua estrangeira, no currículo de escolas públicas que atendem comunidades integradas por descendentes de imigrantes, ficando o critério para escolha dessa segunda língua estrangeira a ser ensinada vinculado, com freqüência, à etnia predominante em uma dada localidade.

Se de início, tais iniciativas tinham um caráter optativo, mais recentemente, em algumas dessas localidades, as propostas têm-se encaminhado na direção da obrigatoriedade dessa língua imigrante como segunda língua estrangeira no ensino público municipal. Um exemplo dessa tendência é o Projeto PLURES (OLIVEIRA, 2008), que promove a inserção gradual da língua alemã, como segunda língua estrangeira, nas escolas públicas do município de Blumenau.

A implantação de tais políticas, no entanto, nos remete a reflexões tanto sobre sua validade quanto sobre sua eficácia, uma vez que as etnias que integram essas localidades se diversificaram ao longo de décadas, e diante do fato de que indivíduos percebidos como oriundos da mesma etnia e falantes de uma mesma língua, freqüentemente, falam dialetos distintos.

Como visto anteriormente, ao apresentarmos o mapa da distribuição étnica, existe aqui a possibilidade para grandes ambigüidades e contradições, já que grupos distintos podem ser percebidos como um grupo único. Contradição agravada pela dificuldade do estabelecimento de quem estipula, ou tem o direito, de estipular tal percepção de unidade.

Outra variável na equação das línguas imigrantes diante de um padrão é a questão do reconhecimento da autonomia dos dialetos. Para estudiosos como Altenhofen, o dialeto Hunsrückisch é autônomo e digno do mesmo lingüístico do alemão padrão.

Poderíamos falar por isso da existência de etnotextos escritos e de uma visão de mundo que reflete a cultura do grupo étnico em questão. O que, no entanto, falta que impeça e justifique uma produção escrita mais significativa e constante, onde antes só havia a oralidade? Constitui uma premissa deste estudo a convicção de que cabe atribuir ao dialeto, antes de tudo, o mesmo status de língua a que têm direito o alemão-padrão e o português enquanto línguas históricas com existência oral e escrita. Isso implica naturalmente a criação de um instrumento inicial de sistematização dessa escrita, como ponto de partida. (ALTENHOFEN et ali, 2003, p. 73) 
Ainda sobre a mesma questão, Tressman (2008), lista 35 línguas de imigração no contexto brasileiro; sua lista, porém, não inclui o alemão em sua forma padrão.

Línguas de Imigração presentes no contexto brasileiro

\begin{tabular}{|c|c|}
\hline 1. Hunsrückisch ou Hunsriqueano & 18. Hebraico \\
\hline 2. Pomerano & 19. Iídiche \\
\hline 3. Vestfaliano ou "sapato de pau" & 20. Francês \\
\hline 4. Suábio & 21. Holandês \\
\hline 5. Wolgadeutsch & 22. Sinti \\
\hline 6. $\quad$ Platt Menonita (Plautdietsch) & 23. Roma \\
\hline 7. Austríaco & 24. Chinês \\
\hline 8. Bávaro & 25. Quéchua \\
\hline 9. Talian (Vêneto brasileiro) & 26. Aimará \\
\hline $\begin{array}{l}\text { 10. demais variedades do italiano } \\
\text { (Moranês, Lombardo, Friulano) }\end{array}$ & 27. Armênio \\
\hline 11. Espanhol & 28. Crioulo de Cabo Verde \\
\hline 12. Polonês & 29. Crioulo Karipuna \\
\hline 13. Japonês & 30. Crioulo Galibi Marworno \\
\hline 14. Okinawa & 31. Crioulo da Ilha Samaracá \\
\hline 15. Ucraniano & 32. Coreano \\
\hline 16. Russo & 33. Letão \\
\hline 17. Árabe & 34. Suéco \\
\hline & 35. Húngaro \\
\hline
\end{tabular}

(TRESSMAN, 2008)

\subsection{Considerações sobre a norma}

Por conta dessas mesmas ambigüidades, é necessário questionar se o tratamento de uma língua imigrante pode ser o mesmo de uma língua estrangeira e que impactos tais medidas podem gerar tanto para os falantes de dialetos quanto para o seu entorno. Afinal, o estudante de língua imigrante teria necessidades distintas das necessidades do estudante de língua estrangeira como afirma Peyton (2001, p.13)

One thing we do know: The instructional needs of heritage language learners are distinct from those of foreign language learners. We need to develop materials, instructional strategies, and assessment procedures and instruments for this new population of learners. We need to develop them not only for the commonly taught languages, but also for those that are rarely taught and are required for national and international commerce, defense, and diplomacy. There is also a 
critical need for teacher recruitment, preservice teacher education, and inservice teacher development (PEYTON, 2001, p. 13).

É, portanto, com o impacto dos esforços para estimular as línguas imigrantes quando estas atingem contingentes falantes de dialetos imigrantes, que se preocupa esta pesquisa, na medida em que entendemos que, ao atingirem esses contingentes, tais políticas podem perder seu caráter de incentivo a uma língua imigrante para adquirir um caráter meramente padronizador de um patrimônio lingüístico que não parece precisar de estímulo, pois permanece vivo, ao contrário de suas variantes padrão, cujo número de falantes parece decrescer. Como sugere Calvet (2002, p. 62), ainda que o dialeto possa ser interpretado como uma variante baixa, estaríamos diante da realidade de que as variantes baixas tendem à ascensão.

De modo mais geral, a história nos mostra que quase sempre o futuro das variedades "baixas" é vir a ser variedade "alta" (foi esse o caso das línguas românicas, francês, espanhol, português etc., com relação ao latim). (CALVET, 2002, p. 62)

É interessante perceber-se também que a distinção entre esses dialetos e suas variantes padrão correspondentes não ocorreu por acaso e que a separação dessas línguas decorreu, em boa parte, de esforços para a afirmação do valor de um grupo sobre outro. Parece estarmos diante da realidade de que tal diferença tenha subsistido até hoje por beneficiar um grupo em detrimento de outro. Ainda que agora nos encontrássemos diante de reformas que visassem reverter essa separação, teríamos de nos perguntar por que agora e se não representam tais esforços tão somente novas estratégias de dominação para o mundo globalizado. Poderia o estímulo à variante padrão representar apenas um novo modelo que reforça, por contraste, o prestígio de uma elite regional, por conta de uma proposta distante da realidade? Ou seriam tais esforços medidas desesperadas para a conversão de falantes de dialeto em falantes de uma variante padrão que tende a desaparecer, levando consigo o diferencial que agrega status a um grupo?

É bom ressaltar, desde logo, que o prestígio social das variedades lingüísticas das classes favorecidas, dominante, não tem nada a ver com qualidades intrínsecas, com algum tipo de "beleza", "lógica" ou "elegância" inerente e natural a essas maneiras de falar a língua. Esse prestígio social é uma construção ideológica: por razões históricas, políticas, econômicas é que determinadas classes sociais - e não outras - assumiram o poder, ganharam prestígio ou, melhor, atribuíram prestígio a si mesmas. (BAGNO, 2003, p.66) 
Diante do que nos diz Bagno, não seria difícil lembrar que a simples oferta de uma variante "superior" remete, pela natureza do próprio discurso, a questões da inferioridade do dialeto e, por conseguinte, daqueles que o utilizam.

A realidade das variantes padrão parece encontrar-se estreitamente ligada à questão da educação formal como um todo e, no caso dos dialetos falados no campo, somos forçados a examinar a questão da inserção de um modelo lingüístico que depende de outros fatores cuja eficácia não parece estabelecida.

A norma-padrão está estreitamente ligada à escola, ao ensino formal, e como no Brasil o acesso à educação é mais um elemento que contribui para a nossa triste posição de campeões da desigualdade social, é fácil imaginar que a normapadrão tradicional tem poder de influência praticamente nulo sobre os falantes das variantes mais estigmatizadas. (BAGNO, 2003, p.69)

Em seu comentário sobre a norma-padrão, Bagno dirigia-se à norma na língua portuguesa, porém, o autor deixa clara a conexão entre a qualidade da educação e a viabilidade da variante padrão. Quando incorporamos essa conexão às considerações sobre esforços de padronização, essa realidade torna-se ainda mais nítida diante do fato de que, como sugerem a mídia e nossos entrevistados, o dialeto é, predominantemente, a língua dos mais velhos. Caso o esforço escolar seja bem sucedido na conversão de falantes de dialeto ou no alistamento de novos falantes, essa nova variante ainda assim estará bem distante da realidade lingüística da comunidade. Iniciativas, mesmo que originárias de demandas das próprias comunidades, ainda que tais comunidades sejam depositárias da variante padrão, incorporam o risco de gerar políticas que transbordam sobre comunidades de falantes de dialetos, onde seu impacto poderá não ter sido examinado.

São os falantes e não as línguas que são diferentes e é a língua, possivelmente, o mais poderoso instrumento e veículo da construção identitária, tanto do indivíduo como do grupo.

É como se a língua não pertencesse a cada um de nós, não fizesse parte de nossa própria materialidade física, não estivesse inscrita dentro de nós - por isso ela pode ser "maltratada", "pisoteada", "atropelada": a língua é vista como um Outro. É como se nosso modo de falar fosse uma língua inacessível aos olhos e aos ouvidos dos mortais comuns. Por isso, a "língua é difícil" - e não poderia ser diferente, já que é uma "ciência oculta", um saber hermético, quase esotérico. (BAGNO, 2003, p.18)

Parece-nos que podemos estar simultaneamente diante de dois cenários: um onde a variante padrão está sendo levada a determinadas localidades, por conta de um movimento de revitalização que reage ao abandono gradual da língua imigrante, no qual indivíduos sabem 
pouco ou nada da língua ancestral, ou sabem "de casa" a variante padrão; outro onde o indivíduo é falante de dialeto e fica exposto à sobreposição de variante padrão.

Apesar das melhores intenções que tais políticas possam ter, é difícil não perceber-se que esses indivíduos terão necessidades diferentes de aprendizado caso esses cenários se configurem na realidade.

\subsection{0 indivíduo diante das forças linguísticas}

Com relação à validade de estabelecer-se uma reflexão a partir de quatro entrevistas, gostaríamos de relembrar que esta posição encontra respaldo em Tollefson (1991, p.2), que defende uma mudança de abordagem na direção dos estudos de caso.

Tollefson (1991, p.2) julga serem os estudos de casos extremamente relevantes para as questões referentes às escolhas individuais e poderosos para ilustrar o impacto de políticas na vida das pessoas afetadas, constituindo-se em instrumento neutralizador da arbitrariedade inerente aos mecanismos de política lingüística. Tollefson ainda deixa implícita a questão de que nossas escolhas lingüísticas importantes estão, por conta da própria importância, sujeitas a pressões.

For this reason, language policies are often seen as expressions of natural, common sense assumptions about language in society. This book explores how the mechanism of language policy arbitrarily gives importance to language in the organization of human societies.

In each chapter, I will present a case study of an individual facing important language choices. (grifo meu) (TOLLEFSON, 1991, p. 2)

Com relação a essas pressões, Hornberger (2002, p.31) salienta a importância do que chamou de "forças gêmeas da globalização e da fragmentação étnica" que afetam a ideologia de uma única língua. Ainda segundo Hornberger (2002, p.31), o fenômeno teria origem no que May chamou de uma "reavaliação dos limites da soberania do estado nacional-moderno por conta da "crescente influência de empresas multinacionais e de organizações políticas supranacionais".

May suggests that modern nation-states have had to reassess the limits of their sovereignty as a result of the rise of globalization and the "burgeoning influence of multinational corporations and supranational political organizations," while at the same time minority groups increasingly exert their rights "either to form their own nation-states... or for greater representation within existing nation-state structures" (MAY apud HORNBERGER, 2002, p.31). 
Embora os efeitos no leste europeu possam ser distintos dos efeitos no vale do Rio dos Sinos, é inegável que a globalização tem potencial para afetar a hierarquia das escolhas lingüísticas por meio de diversas promessas.

O que talvez não tenha sido, todavia, contemplado é que tais forças gêmeas possam ser apenas, duas faces de um único processo. Em suma, a fragmentação étnica também pode ser interpretada como outra faceta do processo de globalização e decorrente do desejo de realinhamento de determinados grupos.

Hornberger, citando Gal, ainda nos mostra, de forma bastante clara, como a natureza dos movimentos globais altera a natureza de propagação e manutenção lingüísticas em termos que não são estáveis, e que parecem em rumo a um modelo de diversidade estratificada, em que línguas locais desaparecem ou se tornam subordinadas a línguas mundiais, fato que parece concordar com os dados coletados em nossas entrevistas.

Gal suggests what might be considered a linguistic corollary to these pressures when she notes that global processes like colonization, the expansion of capitalism and transnational labor migration have replaced earlier processes of "dispersion of populations and the peopling of the world," such that: 1) The characteristic form of language change in the modern era is the coming together of languages; and 2) The former "relatively egalitarian linguistic diversity, based on small-scale languages whose speakers believe their own language to be superior, [has been changed] into stratified diversity: local languages are abandoned or subordinated to 'world languages' in diglossic relations..." (GAL apud HORNBERGER, 2002, p. 31)

Os avanços tecnológicos e científicos das últimas duas décadas promoveram uma aceleração radical e, possivelmente, inesperada do processo de globalização, que veio a materializar-se de maneira não antecipada, agregando valor às línguas mundiais, sobretudo ao inglês, que se tornam cada vez mais importantes e indispensáveis em escalas que seriam inimagináveis para a maioria das pessoas há ainda bem pouco tempo. O advento do computador pessoal e, posteriormente, da internet, também contribui para a cadeia de eventos, que nos traz ao processo que se convencionou chamar de globalização e que reorganiza a hierarquia lingüística, em diversos planos, que ironicamente promovem as línguas minoritárias em prejuízo das línguas nacionais, por conta da perda de prestígio dessas últimas diante da universalidade da língua inglesa como língua global. Em um exemplo prático, podemos promover uma língua como o alemão, por conta de sua suposta utilidade para o mundo globalizado, ao lado do inglês, sem sequer nos perguntarmos que papel poderia ter o próprio Português, falado por milhões de pessoas ao redor do mundo, nessa nova ordem mundial caso decidíssimos promovê-lo como língua mundial. 
All of this points to two countervailing trends working together to break apart the one language-one nation ideology: the rise of English as a global language, hence infringing on national languages; and the reclaiming of endangered indigenous, immigrant, and ethnic languages at local and national levels, hence undermining the ascendancy of national languages (HORNBERGER, 2002, p. 32).

É exatamente com base nessas mudanças paradigmáticas que encontramos a lógica por trás de políticas linguiísticas, que não colidam com os objetivos educacionais, nos termos propostos pelo legislador, para que não incorram o risco de gerar interferência na formação educacional do indivíduo, formação essa cujo objetivo é o de inserir esse indivíduo, de forma eficaz na sociedade.

\subsection{Línguas imigrantes na sala de aula}

Em nosso cenário, a política de ensino para línguas imigrantes estará invariavelmente subordinada à política de ensino de língua estrangeira.

Segundo Kloss (1997, p.xxv), os direitos lingüísticos para grupos étnicos podem ser orientados à tolerância ou orientados à promoção. A tendência em nosso contexto, ao longo das últimas décadas, parece abandonar uma posição de tolerância para avançar na direção do incentivo. A motivação para tal incentivo reside essencialmente na percepção de que línguas minoritárias representam um recurso.

A percepção de língua minoritária como recurso parece ter origem em políticas norteamericanas que enfatizam o valor de línguas minoritárias para a segurança nacional.

\footnotetext{
The National Security Education Act of 1991 further reinforced the foreign language study objective "to equip Americans with an understanding of less commonly taught languages and cultures and enable the nation to remain integrally involved in global issues related to U.S. National Security" (GAMBHIR, p. 210)
}

Em nosso contexto, no entanto, a língua imigrante é um recurso, sobretudo econômico, algo que fica muito claro ao se analisar as propostas de incentivo e perceber-se como estão relacionadas a questões como o mercado de trabalho e interesses multinacionais em tempos de globalização. Até o momento, essas propostas parecem restritas à inclusão das línguas imigrantes nos currículos escolares de determinadas localidades, dando-se às línguas imigrantes tratamento de língua estrangeira, sem o reconhecimento das necessidades específicas dos falantes dessas línguas. Tal tratamento pode propiciar ambientes heterogêneos que criam obstáculos para o ensino e para o aprendizado dessas línguas, como aponta Gambhir (2001, p.216), ao referir-se aos diferentes níveis de facilidade para o idioma, entre o aluno que venha de um contexto de língua imigrante como língua materna e outro que seja um 
verdadeiro iniciante nessa mesma língua. Para Gambhir (2001, p. 216), tendo-se em mente que alguns alunos poderão ter apenas vínculo cultural ou étnico com a língua, o curso correto exigiria duas trilhas: uma para falantes da língua imigrante e outra para verdadeiros iniciantes. Um raciocínio que nos parece ainda mais relevante quando se trata de falantes de dialetos - já que os desafios impostos pelos mesmos parecem semelhantes aos impostos pelo que Gambhir (2001, p.216) chamou de línguas imigrantes aparentadas que acelerariam o aprendizado da língua imigrante sendo ensinada. Essa consideração é extremamente importante já que a presença de falantes de dialeto em um ambiente heterogêneo significaria que esses falantes teriam mais facilidade e aprenderiam mais rapidamente a variante padrão sendo ensinada a título de língua estrangeira, causando um descompasso para os alunos que não falem a língua imigrante dentro dessa sala de aula.

Segundo Ruíz (apud WILEY, 2001, p. 102), existem dois grandes ramos de políticas lingüísticas voltadas ao multilingüismo: o endoglóssico e o exoglóssico. O primeiro ramo de políticas é voltado à primazia e à promoção de línguas locais ou nativas ${ }^{3}$ da comunidade, enquanto políticas exoglóssicas promovem línguas para comunicação mais ampla.

Políticas mistas visariam à promoção de ambas. Como vemos em Vilela (2004), o alemão falado pelos descendentes de imigrantes existe em diversas formas que são o resultado da interação da língua que foi trazida da Europa com a realidade em torno do grupo de falantes.

\footnotetext{
"Não existe um dialeto teuto-brasileiro unificado. A língua falada pelos descendentes de alemães é, de uma forma ou de outra, formada por diversos dialetos e misturada com o português. Os dois fatores dependem do grau de escolaridade daquele que fala. Os mais velhos, na zona rural, falam mais alemão que os jovens nas cidades. (VILELA, 2004)
}

Aqui nos deparemos com uma consideração importante, na medida em que devemos pensar os termos "local" e "nativo" como significando tudo aquilo que pertence e é natural da terra, de uma localidade, e pertencente a uma comunidade. Nesse sentido o esforço pela preservação do dialeto imigrante talvez se aproxime mais do paradigma endoglóssico do que do exoglóssico, já que teria um objetivo distinto do encontrado na instrução voltada a atender uma demanda por uma língua de comunicação ampla.

A distinção entre o dialeto e a variante padrão, entre o clássico e o vernáculo é reconhecida por Fishman (2001, p. 94) que afirma, com relação ao contexto norte-americano de línguas minoritárias, serem os pais dos alunos de línguas imigrantes freqüentemente

\footnotetext{
${ }^{3}$ No original: indigenous
} 
alfabetizados nas línguas envolvidas e que as variantes padronizadas dessas línguas são, portanto, parte da herança que trazem para o estudo dessas línguas - uma situação que não parece ser a norma no contexto brasileiro.

Fishman ainda informa que, com freqüência, o ensino de línguas imigrantes nos Estados Unidos ocorre em heritage language schools, algumas das quais utilizam (sem pagar aluguel ou mediante uma quantia simbólica) dependências de escolas públicas e universidades. Com exceção do caso do espanhol, a língua imigrante freqüentemente ocupou, nos Estados Unidos, espaços paralelos aos do ensino regular muito embora tenham sido conquistados benefícios dentro do sistema educacional - seja pelo reconhecimento de créditos acadêmicos ou vantagens para ingresso na universidade.

A realidade dessa separação também é tratada por Wiley (2001, p.32) e Peyton (2001, p.19) que apresentam o fato de que o ensino de línguas imigrantes pode ocorrer de forma independente, ou em colaboração com as escolas locais.

\footnotetext{
Although not widely recognized in the United States, a great deal of heritage language education takes place outside the formal school system in afterschool and weekend programs. (WILEY, 2001, p. 32)

Much of Heritage language education takes place in community-based schools; some are operated independently of local schools; others in collaboration with them. (PEYTON, 2001, p.19)
}

Wiley (2001, p.32) também estabelece a necessidade de pensar-se o termo "comunidade" sem dar-lhe conotações amplas e alerta para o fato de que esses programas podem tornar-se apenas medidas simbólicas impostas de fora para dentro. Para Wiley (2001, p.32), "comunidade" é um termo chave na definição de programas de língua imigrante, podendo-se depreender de sua posição que o destino de uma língua imigrante deve ser decidido pelos próprios falantes dessa língua.

To ensure that heritage language programs do not merely become symbolic gestures imposed by outsiders to the community, it is important to define heritage language programs from a community perspective. (WILEY, 2001, p. 32)

A peculiaridade que se impõe sobre o nosso contexto específico de falantes de línguas imigrantes parece derivar da percepção que as localidades com grandes números de descendentes de imigrantes são homogêneas, quando, na verdade, podem ser, em termos lingüísticos, bastante heterogêneas, por conta do número de gerações que já se passaram desde a chegada dos primeiros imigrantes e por conta da mistura como outros grupos. É possível que, nesses casos, exista um senso de comunidade construído mais em torno de 
questões identitárias do que lingüísticas. Talvez as comunidades que usam dialetos sejam as mais homogêneas em termos lingüísticos e mesmo nessas localidades essa homogeneidade não será total já que a tendência da troca gradual pela língua dominante parece universal e percebe-se aqui o mesmo fenômeno descrito por Valdés (2001, p. 42), com relação ao impacto das gerações sobre os falantes de línguas imigrantes, que gradualmente abandonam essas línguas.

In addition, immigrant bilingualism tends to follow a specific generational pattern. Bilinguals of different generations have different proficiencies in English and in the heritage language. (VALDÉS, 2001, p.42)

Ainda sobre a questão da heterogeneidade e sobre a questão da dissociação entre comunidade étnica e comunidade lingüística, é interessante notar que o governo norteamericano, por meio do US Department of Education, faz clara distinção entre etnia e língua e enfatiza que os estudantes, especialmente na escola primária, recebem "instrução de conteúdos" em suas línguas nativas enquanto aprendem inglês - em uma espécie de concessão temporária bem compreendida por Laitin (1988). Esta política tem por slogan a frase: "no child left behind" e, embora possa ser interpretada como um avanço no sentido da diversidade, encerra um objetivo de assimilação.

Student Diversity.

Students in U.S. schools represent nearly every ethnic background and nationality in the world. The most diverse school districts are those in major metropolitan areas such as Los Angeles, New York, Washington and Chicago, but diverse student populations are increasingly found even in smaller cities, towns and rural areas. As a national average, U.S. students in public schools are 61 percent white, 17 percent black, 16 percent Hispanic, 4 percent Asian or Pacific Islander and 1 percent American Indian or Alaskan Native.

In the United States, English is clearly the predominant language for government, business, society and instruction. English is taught to all students, but more than 400 native languages other than English are represented in these same schools. In some schools, especially at the elementary level, students with limited English proficiency receive content instruction in their native language while they learn English. More tha 9 percent of public school students (prekindergarten though $12^{\text {th }}$ grade) are considered to have limited English proficiency. (US DEPARTMENT OF EDUCATION, 2003, p. 14)

Por meio do uso das línguas nativas, nos primeiros anos do ensino fundamental, o governo norte-americano esforça-se para dar condições de igualdade para os mais de 9 porcento dos alunos em escolas públicas que utilizam mais de 400 línguas nativas diferentes do inglês, de acordo com o documento citado.

Não parece haver, portanto, com base nessa afirmação do US Department of Education, intenção de incentivar ou, menos ainda, padronizar as línguas minoritárias nos 
Estados Unidos. A citação acima ainda é especialmente útil para demonstrar que os rótulos étnicos não são universais. No caso norte-americano, a classificação oficial está restrita aos "brancos", "negros", "hispânicos", "asiáticos", "nativos de ilhas do Pacífico", "índios norteamericanos" e "nativos do Alaska". Tal classificação deixa evidente a impossibilidade do tratamento de línguas minoritárias por meio de um conjunto de rótulos étnicos.

Diante do modelo norte-americano, a pergunta que talvez tenha de ser feita é: O que teríamos de fazer, em nosso contexto, para que nenhuma criança seja deixada para trás? Estaremos, por meio de nossos esforços, diminuindo ou aumentando o vale das desigualdes sociais, ao instituir exigências curriculares em sistemas frequentemente precários?

Com relação à oferta de línguas imigrantes, outra iniciativa nos chamou a atenção por tratar-se de um esforço para ensinar a variante padrão para falantes de dialeto de comunidades menonitas no México.

A iniciativa do Serviço Alemão de Intercâmbio Académico (DAAD), que segundo Steffen (2008) teve resultados "respeitáveis", reavivando o alto alemão e permitindo que os estudantes provenientes de comunidades menonitas mexicanas participem dos exames Deutsches Sprachdiplom, nível C1. Também de acordo com Steffen (2008), os menonitas têm alto rendimento por conta da proximidade entre o Plautdietsch e o alemão padrão.

(...) Os cursos tem o objetivo tanto de aumentar os conhecimentos de didática mas também o domínio da língua alemã mesma. Tendo em conta que os professores e alunos praticamente começaram do zero, já que no fundo somente falavam o Plautdietsch, os resultados são mais que respetáveis. Em poucos anos o alto alemão foi reavivado como língua de comunicação creativa e estableceu-se de tal maneira no ensino que agora os alunos do último nível participam regularmente nos exames do Deutsches Sprachdiplom, nível C1 do Marco Comum Europeo de Referência para as Línguas (MCER). Os certificados deste exame permitem o ingresso direto nas universidades alemãs. Este nível é alcançado por muito poucos estudantes mexicanos que têm como fundo exclusivamente o espanhol. A causa principal do alto rendimento dos menonitas nas provas do alemão é sem dúvida o fato de que já dominam o dialeto afim com o a língua padrão, apesar de lingüisticamente o Plautdietsch ser bastante distante do alto alemão. Isto quer dizer que os dois códigos não são mutamente compreensíveis. Um falante do alto alemão geralmente não entenderia a um falante do Plautdietsch, e vice-versa. (STEFFEN, 2008)

Se a iniciativa alemã parece, a primeira vista, semelhante às iniciativas brasileiras, é importante salientar que, na perspectiva mexicana, o dialeto é reconhecido e serve como alicerce para que se agregue o "alto alemão", tirando proveito da "aceleração", gerada pela proximidade de línguas, de que fala Gambhir (2001, p. 216).

A complexidade da questão, porém, não está restrita à proximidade entre duas variantes, já que os menonitas estão sendo comparados aos estudantes mexicanos que só 
falam espanhol - sem que tenhamos dados sobre as aptidões lingüísticas individuais ou peculiares a diferentes grupos no contexto mexicano.

Steffen (2008) fala de alto rendimento ao mesmo tempo em que afirma que os menonitas começam praticamente do zero, por conta das diferenças entre as variantes; algo que não pareceria justificar altos rendimentos a menos que a vantagem aparentemente mínima de saber o Plautdietsch represente, na prática, uma vantagem bem maior do que a descrita - o que, novamente, encontra respaldo em Gambhir (2001, p. 216).

\subsection{Línguas imigrantes e diversidade}

Sobre a questão da diversidade, é importante perceber-se o risco de reproduzir-se, ainda que em escala menor ou diferente, os mesmos erros que já foram cometidos no passado quando da imposição de uma percepção de unidade lingüística que não corresponde à realidade. Sobre tal percepção de unidade, Tressman (2008), alerta para o risco do extermínio de línguas e fala no prejuízo à cidadania.

No entanto, aprendemos que o Brasil é um país essencialmente monolíngue, onde se fala supostamente uma língua, o Português. Estamos mais inclinados a ver o plurilingüismo como uma anomalia. Esta maneira de pensar é mais um produto da história da criação dos estados-nação dos últimos 300 anos, quando se estabeleceu a aspiração de um Povo, uma Língua, tão prejucicial à construção da cidadania. O Estado-Nação moderno e monoglota foi responsável pelos maiores glotocídios, isto é, aniquilamento das línguas de toda a história da humanidade até o presente. (TRESSMAN, 2008)

Diante dessas reflexões sobre o desejo pela língua única, não podemos deixar de nos perguntar até que ponto não são os esforços por uma variante padrão uma mera reprodução, ainda que em escala diferente, dos mesmos processos que conduziram às línguas nacionais.

Inicialmente, contudo, pode ser difícil perceber-se algum mal nessa movimentação na direção do novo e do mais útil, mas a questão da cidadania é real e é necessário que se pense nos que ficam para trás. Como se sentem, sobretudo, os idosos e aqueles sem acesso aos bancos escolares em um mundo onde não são compreendidos?

Como alerta Vilela (2004), "não existe um dialeto teuto-brasileiro unificado" e essa língua é estritamente vinculada ao grau de escolaridade do falante.

\footnotetext{
"Não existe um dialeto teuto-brasileiro unificado. A língua falada pelos descendentes de alemães é, de uma forma ou de outra, formada por diversos dialetos e misturada com o português. Os dois fatores dependem do grau de escolaridade daquele que fala. Os mais velhos, na zona rural, falam mais alemão que os jovens nas cidades.
} 
Trata-se, na grande maioria dos casos, de uma mistura de dialetos de várias regiões alemãs, entre elas Hunsrück, Vestfália e Pomerânia (hoje em grande parte território polonês). Este idioma desenvolvido pelos imigrantes alemães no Brasil vem despertando o interesse de especialistas, que apontam o perigo de um desaparecimento completo destas variantes dialetais. (VILELA, 2004)

Além da questão da existência de diversos grupos de falantes, existe ainda a realidade de que cada grupo é constituído por indivíduos diferentes em termos de sua proficiência na língua imigrante. Existe, portanto, uma larga faixa de proficiência que se estende desde uma posição muito próxima ao monolingüismo em uma das línguas até a posição muito próxima ao monolingüismo na outra língua. Mesmo diante de uma criança que tenha a língua imigrante por língua materna, o aprendiz de língua imigrante que tenha apenas vínculo cultural e/ou identitário com essa língua estará diante de um nível de proficiência extremamente distinto do seu. Diante da grande facilidade de demonstrar a heterogeneidade das comunidades, como pudemos verificar em nosso trabalho de campo, acreditamos que esse seja um fator de extrema importância.

Segundo Valdés, (2001, p. 40) O falante completamente bilíngüe é um mito e a realidade do bilingüismo está mais próxima da faixa de amplitude expressa abaixo:

\section{A Ab Ab Ab Ab Ab aB Ba Ba Ba Ba Ba B}

Com relação aos novos desafios trazidos para as salas de aula, Gambhir (2001, p. 217) alerta para a realidade de que mesmo os aprendizes que tenham sido expostos a uma língua apenas próxima da língua alvo em casa aprenderão a língua alvo muito mais rapidamente do que os demais alunos. Sobre os diferentes níveis dos aprendizes, Gambhir (2001,p.16) acrescenta que pode ser "difícil para o professor encontrar um ritmo que atenda todos os alunos, mas que "professores experientes tiram proveito da situação para benefício de todos". Gambhir, todavia, enfatiza que o ideal é que esses alunos sejam separados.

Nevertheless, it is undeniable that most heritage learners are able to learn the target language at a greatly accelerated speed, and organizing them in a separate group in unquestionably a pedagogically sound Idea. Recognizing crucial differences in the two populations, some programs have instituted a two-track system despite the added cost. (GAMBHIR, 2001, p. 216)

Com relação aos professores, Gambhir (2001, p.217) alerta para o fato que para eles, muitas vezes, a língua alvo poderá ser segunda língua, ou língua estrangeira. Na medida em que "o ensino não se baseie em gramática e seja organizado em torno de competência comunicativa, a língua tenderá a entrar em áreas de comunicação onde o professor é menos 
proficiente". Ainda para Gambhir (2001, p.217), "os alunos que acham as análises da língua alvo estranhas, os erros de não-nativo divertidos e o seu discurso forçado e lento, podem ter uma experiência pouco satisfatória". Os professores por outro lado podem "achar desconfortável ter na sala alunos que de alguma forma são mais proficientes na língua do que eles". 


\section{CAPÍTULO 4 - ANÁLISE DOCUMENTAL}

\subsection{Análise de artigos}

A tentativa de responder à pergunta central dessa dissertação, ou seja, se a oferta da variante padrão representa um incentivo ou uma ameaça à pluralidade lingüística, teve como ponto de partida uma entrevista que remeteu à pesquisa de artigos jornalísticos sobre o assunto. Para a pesquisa dos artigos, o ponto inicial foi o acervo do Instituto de Investigação e Desenvolvimento em Política Lingüística - IPOL. Esse levantamento inicial seria posteriormente expandido, sempre em torno da questão da convivência com os dialetos, com base em outras fontes impressas e eletrônicas. Artigos do Jornal Zero Hora, de Porto Alegre, mostraram-se particularmente úteis, por serem oriundos de uma coluna dedicada ao tema e três deles integram este trabalho na forma de anexos. Ao longo deste capítulo, buscaremos uma melhor compreensão de nossa questão central, por meio do desses artigos, lembrando que compreendemos a existência da interferência trazida tanto pelo pré-conceito do escritor quanto pelo pré-conceito do próprio leitor.

Alguns elementos contextuais presentes no corpus chamaram nossa atenção principalmente pela maneira, de modo geral, simplista como os veículos de comunicação tratam as questões lingüísticas. Os artigos, no entanto, contêm considerações interessantes sobre o contato lingüístico e sobre as atitudes em torno das línguas minoritárias como veremos a seguir.

\subsubsection{Resgate lingüístico-cultural}

Uma das primeiras questões a chamar a atenção, com relação aos artigos, é a recorrência de uma idéia de resgate, associada aos esforços de inclusão de novas línguas estrangeiras no currículo escolar. O Jornal Zero Hora, por exemplo, por meio das falas de seus entrevistados, retrata, com freqüência, a questão das iniciativas de ensino de línguas estrangeiras como o alemão e o italiano como se fossem sinônimas de iniciativas de reavivamento de línguas imigrantes no Estado do Rio Grande do Sul.

A realidade do ensino é, todavia, diferente e esbarra nas diferentes necessidades de diversos tipos de aprendizes, em virtude de seus diferentes vínculos com suas línguas imigrantes. 
Essas posições de resgate lingüístico podem ser percebidas diante da recorrência de expressões sinônimas de "resgate", ou que fazem alusão ao conceito de "resgate". Segundo a jornalista, Ursula Wieseman representa este posicionamento, como podemos verificar na transcrição de seu depoimento: “Temos de fazer estudos lingüísticos e ensinar a escrever o alemão que se inspira no português para que ele não se perca" (grifo meu). O mesmo desejo parece partilhado, de acordo com outro artigo, de autoria não conhecida, do mesmo jornal, por Gudrun Ahlert Rahmeier, Professora e Vice-Diretora da Escola Estadual de Colinas, no Vale do Taquari, ao dizer que "o ensino de alemão na escola foi um pedido dos moradores (grifo meu) da cidade, cuja maioria é de origem germânica. E parece ter sido grande também o interesse dos jovens em aprender a língua, muitas vezes falada somente em dialetos (grifo meu) pelos mais velhos". Note-se na última citação o uso de "somente em dialetos" e a implicação de se tratarem os "dialetos" de manifestações lingüísticas inferiores. A declaração, veiculada pelo jornal, também faz alusão a uma perda daquilo que agora só resta preservado pelos mais velhos.

Há cinco anos, a Escola Estadual de Colinas, no Vale do Taquari, implantou no currículo escolar o ensino da língua alemã para os alunos da $4^{\mathrm{a}}$ à $8^{\mathrm{a}}$ série. O colégio é um dos tantos no Estado que oferece aos estudantes, além de inglês ou espanhol, o idioma que pode ser um importante diferencial no mercado de trabalho. Segundo a Professora e Vice-Diretora da instituição, Gudrun Ahlert Rahmeier, 62 anos, o ensino de alemão na escola foi um pedido dos moradores da cidade, cuja maioria é de origem germânica. E parece ter sido grande também o interesse dos jovens em aprender a língua, muitas vezes falada somente em dialetos pelos mais velhos (ZERO HORA, 2005, p.40).

A contradição fundamental inerente à oferta da língua alemã, no caso específico do Vale do Taquari, por exemplo, com base na transcrição jornalística do depoimento de Rahmeier, reside no fato da demanda por uma língua européia moderna ser originária de moradores que, segundo o depoimento transcrito no artigo de autoria não conhecida, são de origem germânica e falam somente dialeto.

Essa demanda pelo ensino da língua alemã só adquire lógica diante da pressuposição de se tratarem, dialeto e variante padrão, da mesma coisa. Desse modo, se são a mesma coisa, estamos diante de indivíduos para os quais a variante padrão não seria, de fato, língua estrangeira. Mas a situação é ainda mais complexa porque os jovens, segundo o artigo, não falam a língua dos mais velhos e, portanto, tanto o dialeto quanto a variante padrão seriam línguas estrangeiras para eles, se não fosse pela existência do vínculo cultural e identitário que têm com a primeira e que faz do dialeto sua língua imigrante. 
Diante do mesmo artigo, as duas variantes parecem equivalentes para o leitor que pode ser levado a crer que a escola tem meios para transmitir a língua imigrante de forma mais eficaz do que as próprias comunidades de falantes.

Para que as políticas de inserção da variante padrão possam, portanto, ser implementadas, faz-se necessário um discurso de não reconhecimento da variante dialetal. Esse discurso nos parece bastante visível, tanto nas amostras de depoimentos veiculados pela mídia como em alguns dos depoimentos colhidos para este trabalho. O critério para a definição do que é estrangeiro em termos de ensino de língua na região sul parece ser étnico e não lingüístico; tal critério nos parece criar uma contradição ao tratar a variante padrão da língua como matéria escolar "língua estrangeira moderna", mas utilizar a origem étnica das comunidades onde as escolas estão inseridas, comunidades nas quais o dialeto falado é constitutivo do modo de vida e não é mero item curricular, para justificar a oferta da mesma variante padrão.

Declarações como as que vimos têm aparecido com recorrência, ganhando espaço, sobretudo, na imprensa sul-rio-grandense. Tais declarações, em geral, partilham uma característica: a da falta de dados para substanciá-las.

Ainda segundo Brum (2005, p.40), há indivíduos que reconhecem as variantes lingüísticas, como a lingüista que alemã está, segundo o jornal, organizando um dicionário e pretende criar fonemas para representar a escrita do alemão falado pelos descendentes germânicos no interior de Venâncio Aires, no Vale do Rio Pardo.

A voluntária aposentada Ursula Wiesemann, 72 anos, sustenta que essas comunidades se comunicam com um alemão aportuguesado. Diferentemente do que se pensava, elas não utilizam dialetos nem falam de forma errada. (grifo meu) (BRUM, 2005, p.40)

Tais declarações freqüentemente esbarram no simplismo imposto pelo meio jornalístico e podem contribuir para a disseminação de percepções errôneas sobre o patrimônio linguí́stico das comunidades falantes de dialetos e sobre o seu possível destino lingüístico. Some-se a isso o risco decorrente da interferência de políticas lingüísticas, ainda que bem intencionadas, não afinadas com os desejos de uma comunidade lingüística no que tange reverter uma possível perda lingüística ou proteger o patrimônio lingüístico:

Beginning in the late 1970 s and continuing through the 1990 s, scholars with a an interest in understanding the role played by language in the reproduction of social and economic inequality, and influenced by critical and postmodern theories, began to question some of the assumptions which informed the early work in LP. For example, reflecting on the role of linguistics in language-planning activities in newly independent states, a number of scholars argued that rather than 
recording languages or providing neutral descriptions of sociolinguistic reality, linguists had helped create languages (CROWLEY apud RICENTO, 2006 p. 13).

É importante ainda salientar que certas iniciativas podem estar utilizando interpretações livres do que é prescrito pelo legislador que abriu espaço para a autonomia das comunidades, sem talvez levar em consideração que essas comunidades não fossem constituídas, ou representadas, de forma homogênea. Tal fato acarreta questionamentos sobre as possíveis motivações dos grupos dedicados a tais iniciativas, uma vez que parece ser consenso na comunidade acadêmica, e em especial para os grupos de estudiosos ligados à área da sociolingüística, que a interferência nesses sistemas não pode ser desvinculada de propósitos e interesses de cunho político, como freqüentemente lembra Tollefson. Tal interferência possivelmente também é motivada, ainda que de forma não consciente, pelo desejo de manutenção ou de promoção do poder de determinados grupos em termos de seu prestígio e posição social, como nos diz Ricento (2006, p. 13), ao afirmar que contextos de diglossia estável são acompanhados de desdobramentos sobre o status das línguas componentes do sistema. Parece-nos bastante claro que, apesar de ter-se aproveitado de línguas coloniais como exemplo, Ricento aponta para o potencial desestabilizador da interferência sobre qualquer comunidade onde existam línguas em contato.

The result - stable diglossia - had the (perhaps unintended) effect of lowering the status and relegating the domains of indigenous languages to local uses, while elevating the status and extending the domains of the former colonial language to national political and elite educational sectors, helping to perpetuate the stratified, class-based structures of the colonial era. (RICENTO, 2006, p. 13)

Como alternativa para o ensino obrigatório do inglês, a sociedade tem testemunhado o surgimento de iniciativas cujo impacto pode não ter sido suficientemente avaliado de uma perspectiva sociolingüística. Artigo publicado no Jornal Zero Hora, sob o título "A língua dos avós no currículo escolar", relata a situação no Estado do Rio Grande do Sul, onde esforços locais têm promovido a inclusão de outras línguas nos currículos de diversos municípios. Daniel (2000, p. 48)

O inglês e o português perderam a exclusividade nas salas de aula gaúchas para idiomas que refletem a ascendência predominante de moradores de pequenos e médios municípios. Nas escolas da rede estadual de educação [do R.G.S.], além do inglês, são ensinados francês, alemão, italiano e espanhol, conforme registro da Secretaria Estadual da Educação (grifo meu) (DANIEL, 2000, p. 48)

O mesmo artigo, porém, aponta contradições que deveriam servir de alerta para os legisladores e comunidades envolvidas com o planejamento curricular no que diz respeito ao 
ensino de línguas estrangeiras para comunidades diferenciadas, pois o mesmo artigo que afirma que os alunos dessas comunidades "nem bem ingressaram no bê-á-bá do português e já enrolam a língua para falar idiomas que não o materno", também nos diz, desta vez ao citar o Professor de alemão Altair Luis Bender, referindo-se às dificuldades dos alunos com relação à variante padrão: “- Eles falam o dialeto ao chegar à escola, mas têm dificuldade de escrever”.

Com base no artigo, se esses alunos falam dialeto ao chegar à escola é porque têm o dialeto por língua materna ou são provenientes, pelo menos, de um contexto de bilingüismo, onde este dialeto exista possivelmente "misturado" com o português. Tal condição, no entanto, parece contradizer a afirmação sobre os alunos terem de enrolar a língua para aprender idiomas que não o materno, afinal a análise da afirmação de que "nem bem ingressaram no bê-á-bá do português e já enrolam a língua para falar idiomas que não o materno" (grifo meu) parece pressupor o português como sendo a língua materna dessas crianças - algo que segundo o jornalista não esclarece.

A afirmação serve para evidenciar a confusão existente com relação à língua materna desses falantes. No plano do discurso, parece haver a pressuposição de que a língua materna é, por definição, o português e "nem bem ingressaram no bê-á-bá" parece significar o início do aprendizado da forma escrita da língua portuguesa. A afirmação do professor de alemão, segundo o artigo, colocaria o aprendizado da forma escrita do alemão padrão no mesmo patamar do português, a não ser pelo detalhe de que ele próprio reconhece que as crianças sabem falar a forma dialetal, e não a variante padrão, ao chegar à escola.

Se falarem dialeto em casa, quando este não é a língua estrangeira sendo ensinada na escola, os alunos permanecem, em relação à variante padrão, diante de uma língua potencialmente tão estrangeira quanto qualquer outra. Potencialmente, a variante padrão de uma língua é menos estrangeira em relação ao dialeto do que outra língua. No caso, a variante padrão do alemão é potencialmente menos estrangeira para os falantes de dialeto do que o francês, por exemplo. Isto porque entre a variante padrão e o dialeto poderão existir muitas semelhanças em termos de sintaxe e léxico. Por outro lado, vão existir enormes diferenças também, que, potencialmente, não só não eliminam as dificuldades de aprendizado da variante padrão como criam outras.

O dialeto parece ser tratado como se fosse a variante padrão, a ponto de afetar as expectativas dos professores quanto ao aprendizado da forma escrita da variante padrão. $\mathrm{O}$ termo "dialeto" parece ser, para os professores, apenas uma palavra que não tem implicações sociais, políticas e culturais concretas. 
A implantação, no currículo escolar, de línguas estrangeiras como francês, italiano, alemão e espanhol porque essas refletem a ascendência predominante dos moradores de pequenas e médias comunidades não parece reconhecer a realidade de que ensino bilíngüe é diferente de ensino de língua estrangeira e que ambos são diferentes de letramento em língua materna. Na verdade, ao declarar que o português e o inglês perderam a exclusividade nas salas de aula gaúchas, Daniel (2000, p.48) coloca as duas línguas no mesmo plano. Em seguida, diz que além do inglês, se ensina também francês, italiano, alemão e espanhol, agora colocando o inglês no mesmo patamar desses idiomas - todos estrangeiros, portanto. Porém, isso fere a premissa de que tais idiomas (francês, italiano, alemão e espanhol) passaram a ser oferecidos por serem línguas faladas nas comunidades em que as escolas estão inseridas.

Com relação ao tratamento de língua estrangeira na escola, a variante padrão oferecida será língua estrangeira se o falante tiver o português por língua materna. Este é precisamente o caso do inglês ensinado nas escolas públicas. O inglês é a língua estrangeira moderna ensinada na escola. O português é ensinado do ponto de vista de letramento em língua materna. Ou seja, o aluno já chega à escola falando fluentemente o português, mas não sabe nem ler nem escrever. É a escola que vai fazer o letramento na língua materna.

Quando a oferta da variante padrão coincide com a língua materna do falante, outra que não o português, essa variante padrão não tem caráter de língua estrangeira. Então, se uma criança aprendeu de casa o português do Brasil e o alemão padrão, e, ao chegar à escola, aprende a ler e a escrever tanto em português como em alemão padrão, estamos diante de um contexto de bilingüismo, em que esta criança será letrada nos dois idiomas concomitantemente. Exemplos desse fato são as escolas particulares bilíngües como a Chapel International School, o Colégio Visconde de Porto Seguro, em São Paulo, entre muitas outras, onde os alunos são, ocasionalmente, letrados simultaneamente em dois idiomas. Somente uma terceira língua seria, nesses casos, uma língua, de fato, estrangeira para o aluno.

Essa consideração nos parece importante já que é construída sobre nosso entendimento do que seja língua estrangeira e como será delimitado o campo semântico da expressão para fins de desenvolvimento de políticas lingüísticas voltadas ao ensino público. Em princípio, não nos parece "estrangeira”, como tal, uma língua que já venha sendo utilizada por uma comunidade, em contextos de diglossia, ou o uso paralelo de duas línguas em função de diferenças de contexto para a sua utilização, que são relativamente freqüentes na realidade lingüística de muitas localidades brasileiras.

A heterogeneidade desses sistemas lingüísticos não fica sequer restrita, em muitos casos, ao convívio com apenas um dialeto, ou mesmo, uma única etnia e que pode incluir 
outras línguas, como aponta Daniel (2003, p. 48), ao ilustrar a situação de poloneses no Rio Grande do Sul.

\begin{abstract}
Quem entra na sala de aula da $7^{\text {a }}$ série da Escola Municipal de Ensino Fundamental Nossa Senhora Auxiliadora, na localidade de Bom Jardim, em Guarani das Missões, pode ouvir de um pequeno coro: "dzien dobry". É o bom dia polonês da turma. A canção, as rezas e as brincadeiras educativas praticadas na $1^{\mathrm{a}}$ série do Ensino Fundamental ganham um tom mais sério na $2^{\mathrm{a}}$ série, quando os meninos são alfabetizados em polonês clássico. Giovani Lunkes não descende de poloneses, mas, em meio aos polacos, já sabe que zaba quer dizer sapo e que czesc significa oi. Ele promete ensinar o idioma aos pais, descendentes de italianos. (DANIEL, 2003, p. 48)
\end{abstract}

Na comunidade mencionada acima, segundo o artigo, o polonês parece, ser utilizado correntemente e as crianças o aprendem na escola aparentemente num contexto de letramento em língua materna. Ou seja, são alfabetizados em polonês clássico ao mesmo tempo em que são também alfabetizados em português, já que são falantes dos dois idiomas. No caso dos descendentes de poloneses, não se pode negar que o aprendizado da língua padrão traz uma referência cultural que toca a cultura trazida pelos seus antepassados. Entretanto, o garoto Giovani Lunkes, que não descende de poloneses, ainda segundo o artigo, está exposto, nessas mesmas aulas de polonês clássico, a um idioma para ele verdadeiramente estrangeiro.

Em seu artigo, Daniel pretende mostrar a pluralidade lingüística no estado do Rio Grande do Sul, mas não consegue esquivar-se da realidade de que a diversidade contém paradoxos. A heterogeneidade lingüística dessas diferentes comunidades mostra que o desenvolvimento de políticas lingüísticas que tenham por base critérios étnicos e não lingüísticos podem provocar um impasse: se tomarmos por base o mesmo artigo, na mesma sala de aula poderíamos ter o polonês clássico sendo oferecido, ao mesmo tempo, para alunos que trazem esse idioma de casa e para o aluno descendente de italianos cuja herança cultural não inclui essa língua. Na mesma sala de aula, portanto, poderíamos estar, simultaneamente, diante da tentativa de letramento em uma língua materna para alguns e diante de uma tentativa de ensino de língua estrangeira para outros. Ainda que não entrássemos no mérito do valor dessa língua estrangeira para o aluno não pertencente ao grupo majoritário, teríamos de nos perguntar se os objetivos de ensino e respectivas metodologias não ficariam comprometidos pela ambivalência da abordagem.

\title{
4.1.2 Trabalho
}

Outro aspecto abordado no artigo publicado pelo Jornal Zero Hora, intitulado "Língua alemã conquista espaço nas salas de aula", é o diferencial que a língua alemã representa no 
momento da conquista de um emprego. No artigo, que deveria dar conta do valor educacional das iniciativas em andamento no Estado do Rio Grande do Sul, o único exemplo de colocação profissional apontado é o do jovem Pedro Kipper, de Lajeado. Entretanto, pelo menos segundo o artigo, o jovem não parece ter estudado em escolas públicas e sua trajetória com o idioma, podemos depreender, vai da experiência em uma escola particular ao intercâmbio no exterior, num percurso que parece distante da realidade dos bancos escolares da rede pública, beneficiários das medidas que o autor do artigo visava promover.

Um diferencial para o emprego

Pedro Kipper, 21 anos, de Lajeado, deve ao conhecimento da língua alemã a conquista do primeiro emprego. O estudante de Administração de Empresas atua como assistente de importação marítima na empresa de logística Kuehne + Nagel, em Porto Alegre. A multinacional com matriz na Suíça tem 600 escritórios em 96 países. Coordenando embarques de itens como produtos químicos, peças automotivas e máquinas agrícolas, Kipper usa o idioma ao negociar o processo de transporte com grupos alemães. O jovem teve a primeira experiência com a língua na $4^{\mathrm{a}}$ série do Colégio Evangélico Alberto Torres. Estudou o idioma até concluir o Ensino Médio, fez intercâmbio em Staufen, na Alemanha, e se especializou em transportes num curso técnico ministrado em alemão no Colégio Humboldt, em São Paulo.

- Tive incentivo da família para estudar alemão. Eu imaginava que a língua me ajudaria no futuro profissional, destaca.

(ZERO HORA, 2005, p.40)

Restringir as escolhas lingüísticas às realidades locais, pode ter um lado positivo e um lado negativo. Por um lado, pode mesmo propiciar melhores oportunidades no mercado de trabalho local. Por outro, pode dar margem para que se relegue a um segundo plano, por exemplo, o valor educacional da língua inglesa como língua valorizada pelo mercado de trabalho em geral. Além do mais, o critério para implantação de políticas lingüísticas no sul parece oscilar, sendo ora étnico - tomando como base a descendência majoritária da comunidade; ora econômico - de acordo com a demanda do mercado de trabalho local. O que nos parece é que o critério para implantação de políticas lingüísticas não tem um componente linguiístico. A falta de critérios claros e amplos pode também resultar em políticas lingüísticas que ignoram a tendência pós-moderna de mobilidade onde a universalidade do capital cultural é de altíssimo valor.

As declarações apresentadas no contexto ao mesmo tempo poderoso e simplista dos artigos de jornal, “A Língua dos Avós no Currículo Escolar” (DANIEL, 2000, p.48) e "Língua Alemã Conquista Espaço nas Salas de Aula" (ZERO HORA, 2005, p.40) ilustram a confusão sobre os conceitos de língua materna, segunda língua e língua estrangeira e as implicações no ensino de cada uma, e a falta de critérios claros na definição das políticas lingüísticas nos preocupam e levam a desdobramentos da nossa pergunta principal, ou seja, se 
a oferta da variante padrão de línguas imigrantes para falantes de dialeto na escola pública constitui uma ameaça ou um incentivo à pluralidade lingüística.

O que parece de imediato saltar aos olhos, com relação à oferta desses idiomas é que as comunidades de ascendência majoritariamente européia não são todas iguais. O que o artigo citado abaixo não deixa claro é que o oferecimento da língua estrangeira não se dá na escola pública dessas comunidades da maneira como o mesmo artigo quer fazer parecer, como se tivéssemos um cardápio de línguas européias do qual o aluno pudesse escolher o curso que mais se adaptasse aos seus desejos e necessidades. A escolha da língua oferecida, nos casos onde isso ocorre, é feita em função da etnia majoritária da localidade, ou seja, aparentemente pressupondo-se uma predisposição ou inclinação dessa comunidade para o idioma correspondente ao de seus ancestrais, como nos lembra a declaração de Gudrun Ahlert Rahmeier, segundo o artigo do Jornal Zero Hora (ZERO HORA, 2005, p. 40).

Em outro trecho do mesmo artigo, encontramos dados sobre a situação atual da propagação do ensino do alemão no Estado do Rio Grande do Sul, desta vez, na transcrição de falas de Darli Breunig, Diretor do Instituto de Formação de Professores de Língua Alemã, em entrevista para o jornal.

Idioma é alternativa a inglês e espanhol. Cidades como Agudo, Candelária, Cerro Largo, Colinas, Ijuí, Lajeado, Santo Cristo, Santa Cruz do Sul, Teutônia e municípios da região do Vale do Sinos são locais citados por Breunig. Para ele, a atenção ao futuro profissional, proporcionando aos estudantes um diferencial no currículo, e a valorização cultural de um dos povos colonizadores do Rio Grande do Sul são dois importantes fatores para explicar o aumento de escolas com alemão ensinado na sala de aula (grifo do autor do artigo) (ZERO HORA, 2005, p. 40).

Tais esforços de incentivo à pluralidade lingüística têm desconsiderado o fato das comunidades de ascendência imigrante não terem se desenvolvido de forma uniforme em nosso território e impõe, caso quiséssemos incentivar as línguas imigrantes, desafios particulares e constante mudança em função de transformações sociais e tecnológicas que afetam percepções de usabilidade e prestígio das línguas e a relação das mesmas com seus possíveis usuários e herdeiros.

Em seu artigo "A língua dos avós no currículo escolar", Isaura Daniel relata que "a maioria das crianças têm noção do idioma estrangeiro que estuda"; porém, não vai além para explicar que tais "noções" são, possivelmente, no caso dos falantes de dialeto, correspondentes à faixa de coincidência lingüística entre o dialeto falado em casa e a norma padrão sendo ensinada na escola. Seria ainda interessante estabelecer-se a faixa de 
coincidência entre a variante padrão ensinada na escola e a variante padrão no país estrangeiro correspondente.

É ainda importante compreender-se que afirmações, como as atribuídas à Velida Schneider Tonin (DANIEL, 2000, p.48), que integram o artigo já citado e publicado no jornal Zero Hora, de que o alemão facilita o ingresso em multinacionais alemãs, podem não ser necessariamente corretas, ou, pelo menos, completas.

O alemão auxilia, sim, o ingresso nas multinacionais alemãs que, em geral, não dispensam também o domínio do inglês - idioma escolhido por várias dessas empresas para a quase totalidade de suas operações internacionais. Isso não significa dizer que o conhecimento do alemão não possa ser útil a tais empresas, mas é importante que compreendamos não ser o alemão a única maneira de acesso a esses mercados da mesma forma que as multinacionais de qualquer origem, aqui instaladas, não dispensarão o uso impecável do português. A revista Veja, em recente artigo de Jerônimo Teixeira (2007, p. 89) traz o resultado de um estudo da Johnson O'Connor Research Foundation e Paul Nation com 39 empresas americanas.

Segundo o artigo "a chance de ascensão profissional está diretamente ligada ao vocabulário que a pessoa domina. Quanto maior seu repertório, mais competência e segurança ela terá para absorver novas idéias e falar em público." Ainda de acordo com a matéria, um executivo deve ter um vocabulário de aproximadamente 50 mil palavras enquanto posições de gerência e superintendência pedem algo entre 5 mil e 50 mil; com um vocabulário de até 5 mil palavras, o profissional não passa da chefia de setor. Ainda que a consideração possa parecer exagerada, somos obrigados a refletir sobre o todo de nosso sistema educacional para que ele, de fato, cumpra sua função instrumental de inserção social ao longo das próximas décadas e para que não venhamos a atribuir importância excessiva a componentes educacionais cujo papel no processo de emancipação do indivíduo pode estar estreitamente ligado a outros fatores de igual ou maior importância; em outras palavras, só será emancipado o indivíduo que, munido de suas escolhas lingüísticas, tenha-se equipado para julgar os interesses ao seu redor, tornando-se capaz de escolher o melhor caminho para si próprio à despeito dos interesses externos que possam se impor sobre ele.

\subsubsection{Guerra}

Muitos cenários são existentes nas comunidades falantes de línguas imigrantes do Sul do país. Temos o falante de dialeto que sempre falou dialeto, o falante de dialeto que o trocou 
pelo português, o falante da variante padrão que sempre falou a variante padrão, o falante da variante padrão que a trocou pelo português, o falante de dialeto que o trocou pelo português e pela variante padrão, o falante que só fala português, e mesmo falantes de outras línguas imigrantes minoritárias com relação à primeira, em um contexto de grande complexidade.

Giovani Lunkes (sentado na primeira fila) não descende de poloneses, mas, em meio aos polacos, já sabe que zaba quer dizer sapo e que czesc significa oi. Ele promete ensinar o idioma aos pais, descendentes de italianos. (DANIEL, 2000, p. 48)

A análise deste contexto parece seguir influenciada por um conjunto de generalizações, sobretudo, do possível impacto da guerra sobre as atitudes lingüísticas desses grupos e da universalidade de uma variante específica que parece ter sido eleita para cada contexto regional. Assim, chega-se ao que parece ser uma percepção comum, apesar de não necessariamente correta, de que as comunidades germânicas do sul do Brasil, por exemplo, falam alemão e que o abandono gradual da língua imigrante é decorrente da repressão do período da segunda guerra mundial e do Estado Novo.

Além disso, vale mencionar a realidade desses grupos, onde cada uma das línguas faladas possui valor e função social específica. É necessário ter cautela para que não tentemos o resgate daquilo que não foi perdido e para que se compreenda, de fato, as motivações dos indivíduos que ora propõem tais medidas de ensino de variantes padrão do alemão para comunidades falantes de dialetos. Aqueles que propõem o ensino da variante padrão poderiam estar tentando apenas resgatar suas próprias posições, de quem, em dado momento, abandonou o próprio patrimônio lingüístico. Ou seja, a proposta de ensino pode esbarrar na consciência do fato de que foram os próprios falantes que optaram pelo abandono da língua imigrante nos casos em que isso tenha ocorrido.

É claro que não podemos negar a validade do fato de serem as narrativas subjetivas e de que tais narrativas regem os parâmetros da realidade daqueles que as articulam, mas, exatamente por serem subjetivas, são também sujeitas à releitura, à revisão e ao escrutínio, sejam esses procedimentos derivados da própria reflexão do indivíduo ou trazidos pelo analista por conta de seu distanciamento do problema.

Não podemos ignorar que a "guerra" é, enquanto construto narrativo, a representação extrema da noção de conflito, e que os conflitos, sejam eles drásticos ou cotidianos, e quer ocorram em maior ou menor grau, são inerentes à condição do imigrante.

Dessa forma, a guerra serve à função de cristalizar a narrativa do conflito entre esses grupos da sociedade e de servir como justificativa plausível para a perda de um patrimônio 
que é posto em risco toda vez que um indivíduo opta ou é forçado a viver em uma situação de línguas em contato, ainda que não tenha contemplado ele próprio tal hipótese de perda ou abandono de algo que lhe possa ser tão caro, mas que pela própria natureza de entrelaçamento com a constituição da identidade, raramente é objeto de reflexão.

Em suma, as pessoas, de modo geral, não refletem sobre a língua que falam e o abandono das línguas imigrantes, quando isso ocorre, talvez seja um excelente exemplo a ilustrar o ditado que diz "só darmos valor ao que tenhamos perdido". Sendo que a constatação de perda dessa herança, ocorrida com a sucessão das gerações, se intensifica no encontro com um "outro" que tenha sido capaz de preservar algo semelhante, remetendo a uma possível necessidade desmerecer o que é diferente, talvez por meio da imposição de algo novo, que deverá substituir o que foi, para o outro, preservado em vão.

O êxodo da Itália, em condições de penúria extrema, e a construção de sua identidade étnica em terras brasileiras, em condições de isolamento e enfrentamentos de toda a ordem, minimizaram aos olhos dos imigrantes, mais esta experiência de violência, endurecendo sua sensibilidade? Urna cultura violenta, no caso a européia, daria substrato para «naturalizar» esta nova violência? Os valores presentes na constituição de sua identidade cultural, especialmente a identificação com a moral católica, encobriram a violência durante o Estado Novo? Mas os que sofreram a violência, corno a sentiram e como a re-apresentaram? O que significou para as populações, para quem a língua cotidiana, é a única que conhecem verem-se estigmatizadas, diminuídas e desprezadas por usá-la? Como introjetaram este desprezo? Como o repassaram? Seria o fato de não refletirmos sobre esta questão e sobre o próprio conceito de violência, que a faz bastante invisível? Se os «mitos» justificam, até que ponto o mito nação e «Estado-Nação» amenizaram o fato de ter havido esta violência? O que representou esta violência em termos da redefinição dos valores culturais da época? Em que medida o violentado introjeta os valores do «outro»? (grifo meu) (MOSER, 2004)

Ainda que pudéssemos argumentar ter sido a guerra a grande causadora da perda da língua imigrante, não estaríamos, ao impor uma variante padrão sobre o falante de dialeto, mais uma vez diminuindo os que falam a "língua cotidiana" de que nos fala Moser no trecho acima?

A historiadora Marlene Fáveri (2005), da Universidade de Santa Catarina, que documentou extensivamente a questão dos conflitos entre brasileiros e imigrantes alemães durante a Segunda Guerra Mundial em Santa Catarina, relata vários incidentes que demonstram como a repressão, de ordem predominantemente política e motivada por questões possivelmente legítimas e consideradas de segurança nacional, do ponto de vista do poder central naquela época, gerou resistências possivelmente favoráveis à manutenção da língua imigrante. 
A historiadora Gladis Pippi lembra que o rechaço pelas práticas do líder nazista Adolf Hitler fazia com que o idioma alemão fosse inibido no Estado por determinação oficial. Os dialetos alemães, italianos e poloneses, porém, nunca foram esquecidos nas rodas familiares. (BRUM, 2005, p. 40)

Estudiosos (VALDÉS, 2001, p.42) atribuem a perda das línguas imigrantes de um modo geral a um fenômeno praticamente inevitável que ocorre ao longo de quatro gerações consecutivas. Diante dos dados coletados, o abandono do alemão pelos imigrantes que dele se afastaram parece mais uma decorrência de um processo de crescente urbanização e do menor prestígio inerente à condição de uma língua imigrante, diante de uma língua nacional que acaba desencadeando um gradual language shift na direção do português, predominantemente nas áreas urbanas de nosso país. É inegável que a guerra tenha afetado o prestígio das línguas imigrantes, mas não parece que esse dano pudesse ter caráter permanente a menos que a comunidade escolhesse torná-lo permanente. Porém, a reversão dessa escolha diante da realidade do mundo globalizado pode estar vindo tarde demais além de ser dirigida aos grupos errados. O fato de que tal perda ocorre principalmente na área urbana, e mesmo dentre os falantes da variante padrão, aponta para o prestígio como fator preponderante para que uma língua seja trocada por outra, e não a sua natureza culta ou dialetal. Nos locais onde a língua permanece útil, ela mantém seu prestígio e persiste; nos locais onde perde prestígio, é gradualmente substituída por uma variante de maior prestígio e tende ao desaparecimento.

Tal consideração ressalta a necessidade de determinarem-se as percepções locais e estabelecer-se uma escala de preferências com relação às línguas que se pretenda ensinar para que não venhamos a incorrer no equívoco de ensinar o que possa ser percebido sem valor, onerando, dessa maneira, tanto o sistema educacional como o estudante.

Ou seja, o estímulo a uma variante padrão pode não ser um seguro eficaz contra o abandono de uma língua. Há relatos que parecem demonstrar que o fato de ter sido a variante padrão a variante a ser trazida da Europa não foi suficiente para que a língua não fosse trocada - sobrevivendo, em certas famílias, até uma determinada geração que, todavia, não transmitirá a língua imigrante para a geração seguinte, criando-se assim uma espécie de diglossia generacional, dentro das próprias famílias, quando a língua imigrante é usada para falar com os mais velhos e o português usado para falar com as crianças.

No contexto de perda gradual da língua imigrante ao longo das gerações, é recorrente situação em que as crianças crescem apenas expostas, em maior ou menor grau, e em grau progressivamente decrescente, à língua imigrante, sem aprendê-la, fato que nos leva a uma consideração importante: se estavam expostas por que não aprenderam? E a resposta é 
simples: porque nunca precisaram; porque às crianças todos se dirigiam em português a ponto de gerar-se uma situação em que a língua imigrante, nesses casos, é freqüentemente usada quase como um código secreto destinado aos assuntos dos adultos, que agora podem falar sobre qualquer assunto, mesmo na frente das crianças, sem que essas os entendam. Tal estratégia mostra-se particularmente útil em culturas disciplinadoras onde até um passado relativamente recente, as crianças, muito freqüentemente, não tinham voz ou direitos.

Talvez para as crianças, isto representasse urna norma a mais que se deveria observar sob pena de ser castigado. Era um «não» somado aos muitos que compunham o seu cotidiano. Essas novas normas sociais encontravam justificação nas normas rígidas de sua própria cultura, onde as ameaças eram constantes. No entanto, contribuiu neste momento de sua socialização, para «marcar» o idioma italiano, sua língua, como algo desprezível. Certamente este dado foi deixado no inconsciente como mais uma repressão, invisível mas que poderá explicar a desvalorização da identidade étnica naquele momento histórico. Novamente é a invisibilidade que «atenua» todos os atos violentos. Talvez a geração que mais sofreu as consequiências da desvalorização de sua identidade étnica, foi aquela que estava no período de socialização primária (a terceira geração nascida o Brasil). Cresceram não com o orgulho de ser bilíngüe, mas com o estigma de que sua língua era algo desprezível. Esta cresceu sem ter a consciência de suas raízes culturais. A introjeção desta violência no processo de sua socialização como filhos dos colonos, faz com que, no presente, falar sobre ela produza perplexidades em muitos, dando-se conta da violência sofrida. (MOSER, 2004)

Ainda que os motivos para a perda de prestígio da língua imigrante possam ter sido os mais variados e tenham sofrido o impacto da discriminação trazida por uma guerra, não podemos ignorar a realidade de que o language shift está, em última análise, nas mãos dos falantes destas línguas (KAUFMANN, 2005) que, em dado momento, fazem a escolha coletiva de abrir mão desta herança, não sendo, por isso, justificável a atual promoção com base em um discurso de restituição que aparece com freqüência.

É importante lembrar o que Wiley (2006, p. 136) chama de Limitações da História Convencional, ao apontar para os riscos de acatar-se cegamente o discurso que promove a relevância da história convencional ao lidar-se com questões contemporâneas. No mesmo texto, Wiley deixa um alerta sobre tais apelos à história enquanto oferece um argumento contundente com relação à utilidade do passado como referência para questões atuais.

Today, in popular and scholarly discourse about language politics and policy, demagogues, politicians, and even language-policy specialists occasionally appeal to the authority of history to bolster their claims about how the past informs us about contemporary issues. Such appeals to history are based on the assumption that there is a correct, empirically based, "true" story of what happened in the past. Given the importance accorded to history, this chapter briefly discusses aspects and limitations of conventional historical explanation and imagination, as well as the challenges and paradoxes facing both so-called modernist and postmodernist thought with reference to historical work (WILEY, 2006, p. 136). 
Segundo Wiley, existe uma confiança de que a história convencional, por meio de artefatos históricos e das inferências do historiador, produz uma versão "verdadeira" do passado, ou seja, permite descobrir os eventos "de verdade" que resultaram das escolhas dos agentes do período em questão.

\footnotetext{
Underlying confidence that conventional history provides the correct story of the past is the belief that a "true" accounting of the past is produced from empirical investigations of primary sources, historical documents, records, artifacts, biographies, eye-witness accounts, and other texts, which, through inferential analysis by the historian, allows her or him to discover the "real" events that resulted from the choices of historical agents of the period under investigation (grifo meu) (WILEY, 2006, p. 136)
}

Isso não significa que os eventos narrados, no caso específico dos depoimentos, não tenham ocorrido, ou não sejam verdade. Todavia, esses eventos foram entrelaçados à narrativa dos envolvidos e não podem dela ser separados. Desta forma, agrega-se, ao fato histórico em si, a narrativa de engrandecimento ou vitimização de quem narra os eventos, em um processo que impõe à história convencional o trilhar dos caminhos estreitos dos casos extremos, que acabam registrados ou que deixam marcas fortes o suficiente para sobreviverem no tempo. Entretanto, a ocorrência mediana, que talvez melhor pudesse caracterizar dado momento histórico, é ofuscada pelos episódios extremos.

É esse contexto de contrastes entre o rural e o urbano e o antigo e novo que oferece ao lingüista o material para a análise das tensões inerentes a um contexto de línguas em contato. Alie-se a isso o fato significativo de que em Angelina a língua estrangeira ensinada na escola é o inglês e temos uma oportunidade incomum para a coleta de dados antes que as opiniões de seus habitantes venham a ser influenciadas pelo discurso de novas propostas. A narrativa da vida cotidiana impõe um risco real e sempre presente de interferência do agente do processo histórico (GOFFMAN, 2007, p. 29), interferência que só pode ser minimizada na medida em que o observador entenda que seu papel altera a qualidade dos dados a serem coletados e procure minimizar o impacto de sua própria interferência, além de buscar uma postura, na medida do possível, neutra e imparcial.

Venho usando o termo "representação" para me referir a toda atividade de um indivíduo que se passa num período caracterizado por sua presença contínua diante de um grupo particular de observadores e que tem sobre estes alguma influência. Será conveniente denominar de fachada à parte do desempenho do indivíduo que funciona regularmente de forma geral e fixa com o fim de definir a situação para os que observam a representação. (GOFFMAN, 2007, p. 29) 
Por outro lado, parece bastante claro que a narrativa de vitimização decorrente do período da Segunda Guerra Mundial está bastante incorporada ao discurso dos proponentes de uma revitalização da língua alemã na região, como pode-se constatar no trecho abaixo.

\footnotetext{
A especialista em língua alemã Velida Schneider Tonin conta que os primeiros habitantes da cidade se comunicavam em alemão até a metade da década de 40, antes da repressão ao alemão em razão da II Guerra Mundial.

- O domínio do alemão abre portas de empresas multinacionais da Alemanha aos jovens, diz Velida. (grifo meu) (DANIEL, 2000, p.48)
}

Não podemos ignorar, todavia, pelo menos no caso da língua alemã, que as atuais promessas por melhores condições de emprego por conta da demanda de multinacionais alemãs possa ter mudado o valor do patrimônio lingüístico da região, afetando os modelos de assimilação cultural.

- Atualmente, há a necessidade de se ter outra língua além do espanhol ou do inglês. Multinacionais alemãs no país, principalmente no Sul, também incentivam a busca pelo idioma - observa. (grifo meu) (ZERO HORA, 2005, p. 40)

Uma vez que tenhamos estabelecido que são os falantes, em última análise, que farão a opção pelo manter ou abandonar a língua, a questão da repressão por parte do Estado como fator determinante da troca passa a adquirir a dimensão que de fato lhe pertence, a dimensão da narrativa das identidades e de como as mesmas se constituem, se propagam e se perpetuam.

Parece-nos que esta explicação de terem sido os falantes forçados ao abandono da própria língua, presente inclusive no corpus coletado, é um exemplo claro de como a história da guerra pode ser incorporada, e se incorporou, à narrativa identitária, individual ou coletiva, servindo como eixo simbólico das questões de opressão, marginalização, prestígio e status desses grupos.

Darli Breunig, do IFPLA de São Leopoldo, segundo o jornal Zero Hora, retoma o tema da guerra, mas aponta na direção de que a Segunda Guerra não teria sido o único momento de constrangimento para os falantes de alemão. Curiosamente, Darli Breunig lembra, concordando com Fáveri (2005), que a situação teria sido pior no interior justamente onde os dialetos resistem até hoje.

No Brasil, em especial na II Guerra Mundial, falar alemão chegou a ser um constrangimento, principalmente no Interior, quando era proibido falar línguas estrangeiras. Aos poucos, parece que os descendentes estão voltando a se autoafirmar por meio de suas origens - observa ele. (ZERO HORA, 2005, p.40) 
Parece existir, por parte dos membros dessas comunidades, com base nos artigos, um apego à narrativa de que a guerra e a repressão decorrente do conflito foram a causa do abandono do idioma, em uma narrativa que subentende a retirada desse patrimônio por um grupo, sobretudo, de maior poder. Se podemos argumentar que a guerra e o Estado Novo, de fato, acarretaram prejuízos às línguas imigrantes, também podemos contra-argumentar que os mesmos fatores incentivaram resistência, ainda que a distribuição dessas tendências opostas não possa ser determinada com precisão.

A dúvida, diante do tema recorrente da repressão da língua imigrante, tanto nas áreas rurais quanto urbanas, recai sobre o grau de impacto que tal repressão teria tido sobre o processo de abandono da língua e conseqüente processo de assimilação cultural.

A percepção de que a repressão no período do Estado Novo foi a causa fundamental da perda da língua imigrante está tão integrada à narrativa das comunidades imigrantes nos estados do sul do país que acaba por ofuscar o fato de que a língua dos imigrantes sobreviveu e sobrevive até hoje em inúmeras comunidades, à despeito desses esforços de repressão pelo Estado Novo.

Poder-se-ia argumentar que, diante dessa repressão, as línguas imigrantes só sobreviveriam nas áreas rurais por conta de seu isolamento, mas os relatos apontam para a realidade de uma repressão muito mais intensa no interior do que nas cidades, como vemos em Fáveri (2005). Não é difícil compreender porque a repressão ocorre com maior intensidade no interior se tivermos em mente que em inúmeras localidades rurais predominava a língua imigrante. O uso da língua imigrante no interior, resultado das poucas oportunidades para o aprendizado do português, pode ter sido interpretado como uma resistência deliberada que alimentou o ciclo de conflitos entre "brasileiros" e "imigrantes".

\subsubsection{Assimilação e resistência}

Apesar do sofrimento imposto pela guerra e pela repressão do Estado Novo, as línguas imigrantes sobreviveram. Para Tomquist, em entrevista para a DW-WORLD, a manutenção do alemão como língua materna é admirável.

Mesmo com o constante processo de "assimilação" destas comunidades pelo português brasileiro nas últimas décadas - que teve seu ponto alto durante a ditadura de Getúlio Vargas - o alemão falado em regiões do Rio Grande do Sul, Santa Catarina e Paraná resiste.

(...)

É admirável que, em várias regiões do Rio Grande do Sul, o alemão continue sendo a primeira língua, aquela predileta na comunicação dentro da família 
e entre amigos", comenta a pesquisadora Ingrid Margareta Tornquist, autora da tese Isto aprendi com minha mãe. Linguagem e conceitos éticos entre teuto-brasileiros no Rio Grande do Sul, em entrevista à DW-WORLD. (VILELA, 2004)

Mais provavelmente, a repressão pelo Estado Novo tanto contribuiu para o desaparecimento da língua imigrante nas áreas urbanas, onde os indivíduos tinham mais oportunidades de assimilação, quanto contribuiu para a resistência da língua imigrante em áreas rurais onde os imigrantes não dispunham de outra alternativa além da luta pelo reconhecimento de seu direito de expressão na língua que falavam.

Na verdade, diante das histórias relatadas por Fáveri (2005), é difícil não se perceber que há no interior um apego à língua e um esforço pela sua manutenção, a despeito dos conflitos que tais embates possam vir a gerar; esforço esse que nos parece existir em contraposição a uma possível acomodação por parte dos falantes de áreas urbanas que, diante da imposição do uso mais freqüente da língua do poder central, no caso o português, acabam optando pelo abandono gradual da língua imigrante.

Mesmo no Rio Grande do Sul, onde há várias iniciativas de oferecimento do alemão padrão, há também defensores dos dialetos locais, conforme a citação abaixo, retirada de um artigo do Jornal Zero Hora:

O professor de alemão em duas escolas da cidade Altair Luís Bender, 33 anos, é o primeiro voluntário a receber orientações da especialista sobre a tarefa.

- Temos de valorizar a língua do interior, porque esse alemão é o primeiro idioma que as crianças aprendem. Elas têm de saber que não estão falando errado relata Bender. (BRUM, 2005, p. 40)

Em artigo de Moser (2004) sobre os abusos do Estado Novo contra os imigrantes italianos, encontramos relatos contundentes sobre a violência contra o imigrante da mesma forma que encontramos as condições para que a língua adquira caráter cristalizador de uma identidade étnica coletiva e se articule como instrumento de afirmação dessa etnia e mecanismo de resistência.

Os depoentes avaliam a violência como um «abuso desnecessário»um «excesso», uma «vergonha». O estigma de inimigo da pátria anulou a identidade real e os reduziu ao único aspecto que interessava realçar: não sabiam falar português! Como cidadãos de segunda categoria, assim considerados aos olhos dos governantes, eles tiveram, novamente, a sua cidadania dilacerada e se calaram, introjetaram o medo e submissão. Desenvolveram, também, processos de defesa mútua, como relata um entrevistado que faz comparação entre as atitudes dos italianos e as dos alemães:

«Mas aqui entre os italianos, havia sempre o desejo de se defenderem um com o outro. Estavam sempre de olho, para não caírem as malhas da polícia, eles eram ladinos... Talvez, alguém chamaria covardia, mas da minha parte não, porque em certo sentido, é ser um pouco prevenido, para não ir para a cadeia, deixar um pouco o "barco correr". O alemão, não, ele é mais teimoso. Outros dizem mais 
decidido, mais consciente. Iam para a cadeia, sofriam os rigores da lei e não queriam ceder» (MOSER, 2004)

Faz-se necessário lembrar que a argumentação não tem intuito de defender práticas condenáveis ou negar a ocorrência dos atos de violência. O que deve-se salientar, todavia, é que tamanha violência contra o contingente imigrante agrega ainda mais valor ao esforço de preservação da língua materna, já que é justamente no interior, onde a violência parece maior e mais intensa, que a língua imigrante resiste.

A violência e a prepotência parecem ter sido infinitamente maiores no interior até pelo fato de que os perpetradores desses abusos pareciam gozar de certo grau de impunidade por conta da distância como fator de quebra da hierarquia institucional e da cadeia de responsabilidade. Em outras palavras, se um delegado do interior resolvesse perpetrar um abuso contra um imigrante, existiria muito pouco ou mesmo nada em termos de recurso a uma alçada superior.

A construção do «mito da nação» e do «mito da personalidade» do chefe da nação, a exemplo das ditaduras européias, opera-se por mecanismos de persuasão, mas acima de tudo, pela violência garantida por um bem organizado aparelho policial que perseguia e identificava em todo o tempo e espaço, todo o tipo de dissidentes, deixando-se o caminho livre para múltiplas arbitrariedades. (grifo meu). (MOSER, 2004)

A violência descrita nos relatos reunidos por Fáveri (2005) e nos relatos contidos no artigo de Moser (2004) parece, no entanto, apontar na direção da violência que vem "de baixo", um abuso que parece decorrente, em muitos casos, do desequilíbrio psicológico, do despreparo profissional, da não compreensão da lei, do medo de um inimigo desconhecido por parte de um perpetrador que faz o que faz por estar investido de poder para fazê-lo em um sistema onde tal poder não foi eficazmente vinculado a uma faculdade de discernimento sobre quando e como exercer tal poder.

Havia, no entanto, casos de tolerância dos próprios policiais em relação aos colonos, a não ser que estivessem em presença de seus companheiros. Este fato evidencia que se o jogo da violência obrigava a todos a submeter-se, muitas vezes, o bom senso superava o arbítrio. (MOSER, 2004)

Quando Moser (2004) nos fala da prática de torturar o imigrante pela ingestão forçada do óleo de rícino, relata que a prática parecia existir como uma espécie de vingança decorrente da suposição de ser tal prática de tortura utilizada por Mussoline na Itália. O ponto de Moser é que a violência contra o imigrante tem origem em uma violência que no imaginário do brasileiro é reversa, de certa forma, já que o Brasil sofreu ataques que precipitaram seu envolvimento na guerra. 
De outro lado, sobre o costume de obrigar o «culpado» a ingerir óleo de rícino, com todas as conseqüências advindas do fato, já era conhecido por alguns. Assim se expressa um entrevistado, demonstrando a funcionalidade desta prática fascista:

«Era um castigo, por exemplo, na Itália existia esse costume no tempo de Mussolini. Ele endireitou a Itália com aquele sistema... . Porque a Itália naquele tempo era uma desordem, aqueles socialismos, a Itália praticamente não tava unificada. Ele endireitou a Itália...» (Homem, 86 anos).

Evidencia-se aqui o grau de autoritarismo introjetado. $\mathrm{O}$ que se constatou, muitas vezes, entre os entrevistados, é o fato de afirmarem que diversas pessoas tomaram óleo. No entanto, parece que isto, entre os italianos, ficou somente como crime de ameaça e forma útil de amedrontamento. O que não aconteceu com os alemães pelo fato de existirem relatos comprobatórios desta prática. Conclui-se que o processo de intimidação, através do boato cumpre exatamente um papel fundamental: imobiliza. Embora ninguém veja, o fato está sempre presente. (grifo meu) (MOSER, 2004)

Some-se a isso o fato de que a opressão não foi imposta somente pelos "brasileiros", disseminando-se entre os próprios imigrantes; uma situação em que o alinhamento das lealdades remete diretamente à questão da assimilação competitiva na medida em que os "traidores" da comunidade podem ter percebido a oportunidade para o seu ganho próprio a despeito das conseqüências para os outros membros da comunidade.

O segundo obstáculo para o argumento do isolamento geográfico se encontra no fato de que, a despeito da existência de indivíduos que nunca vieram a aprender o português, segundo os relatos, há também nas comunidades imigrantes a presença de indivíduos bilíngües, o que atesta o alcance do sistema educacional então vigente com relação ao ensino da língua portuguesa, ainda que tenha ocorrido de forma precária e não uniforme.

Ainda que isso pudesse ter ocorrido em termos extremamente precários em certas regiões, não resta dúvida de que existia uma rede, pelo menos minimamente, capacitada a ensinar o português. Além do mais, existia uma razão muito estratégica para que, tanto o ensino regular, de modo geral, quanto o ensino do português tenham tido algum nível de eficácia, apesar da falta de recursos do Estado, em nosso país e, sobretudo, durante um período de guerra: o serviço militar obrigatório.

O Código Eleitoral Brasileiro, Lei Federal 4737/1965, foi instituído no país durante o período de ditadura militar, sob regência da doutrina da segurança nacional, que entre outros dispositivos, no seu art. $5^{\circ}$, II, proíbe o alistamento de todos aqueles que não saibam se exprimir em língua nacional, excluindo além dos falantes de línguas descendentes dos troncos europeu, asiático e africano, todos os povos indígenas falantes de seus idiomas nativos, autóctones, que por sinal eram considerados como relativamente incapazes pelo Código Civil de 1916. (Miranda, 2005, p.2)

Por conta da obrigatoriedade da prestação do serviço militar, o Estado que exige a participação do jovem só tem por alternativa levar a educação até o imigrante para resgatá-lo 
da condição de incapaz. Ainda que, por razões de receita do Estado, pudesse ser mais barato ou conveniente abandonar os imigrantes aos seus próprios recursos, deles extorquindo-se apenas o fruto da sua produção rural, a realidade da segurança nacional é um tanto mais complexa e, especialmente diante da realidade de uma guerra em curso, cuja natureza intrínseca remete a uma incerteza quanto ao seu desfecho e faz parecer absolutamente tudo como sendo potencialmente imprescindível à sobrevivência, tal abandono não seria prudente do ponto de vista da manutenção do potencial de segurança do Estado.

Alfabetizar o imigrante na língua portuguesa, tornando-o capaz para o serviço militar, parece ter sido uma preocupação imediata do Estado, em seu esforço racionalizador, ainda que de um ponto de vista que mantivesse o imigrante na condição de mão-de-obra a serviço das forças armadas - condição essa que parece persistir no discurso sobre a inclusão desses contingentes e que impõe uma reflexão sobre a condição real desses indivíduos que chegaram ao país na condição de "mão-de-obra" e que talvez permaneçam sendo vistos assim.

O exército era a única instituição que configurava concreta e oficialmente sua identificação com o Brasil. Importa salientar que o exército foi a instituição que lhes possibilitou o aprendizado do português. Em depoimento, um entrevistado conta que seu pai pagava aulas extras de português no exército, gastando para isto todo o soldo que recebia como soldado. Este trabalhou depois como negociante e o conhecimento do português, como meio de comunicação, era importante. Este entrevistado me assegurou que em sua casa falavam o português. No entanto, atribuir a qualquer colono de origem estrangeira, o estigma de «quinta-coluna», por não se comunicar em língua nacional transformou-se em algo banal e corriqueiro, deixando marcas profundas nos atingidos pelo estereótipo. (MOSER, 2004)

Entretanto, por questões inerentes à própria natureza do serviço militar obrigatório, também aqui diante de um componente de gênero, já que apenas os homens são obrigados a prestá-lo, mas seria ao mesmo ingênuo supor que todo o esforço de ensino do português pudesse ser deixado para as vésperas do alistamento, sem que se tenha utilizado um sistema educacional público e misto para cumprir tal tarefa. Mesmo assim, é visível aqui uma bifurcação entre o processo de assimilação entre homens e mulheres e não é difícil perceberse a formação de condições para que as mulheres tornem-se as mais importantes depositárias da língua imigrante, reproduzindo-se invariavelmente o ciclo que reforça a natureza "materna" das línguas que falamos

Mas qual o eixo central que conecta a vida do imigrante italiano de um mundo em guerra à experiência de um falante de dialeto alemão em uma pequena cidade como Angelina? A resposta é simples. Ambos, em diferentes momentos e contextos históricos se encontram a mercê de "atitudes", no sentido sociolingüístico do termo, e como tais atitudes podem ser geradoras de tensão social e promotoras de movimentação de indivíduos e grupos 
ao longo de um continuum de tensões. É importante compreender-se que tensões promovem escolhas e que escolhas podem possuir dimensão coletiva e individual, não necessariamente em constante alinhamento. Enquanto uma comunidade está envolvida com a manutenção de seu patrimônio lingüístico, podem existir dentro dela dissidências individuais.

É por esse motivo que devemos analisar questões como a dos dialetos imigrantes neles reconhecendo que uma escolha coletiva já foi feita por parte dessas comunidades. A existência dessas escolhas não impede tais comunidades ou indivíduos dentro delas de fazerem novas escolhas, mas é preciso critério para que releituras da história desses contingentes não venham a influenciar, de fora para dentro, as decisões que até aqui ocorreram de dentro para fora.

É, portanto, fundamental que antes de qualquer outra medida se compreenda a distinção estabelecida pelos teóricos, ao definirem as línguas imigrantes como sendo aquelas com as quais o falante possui vínculo (VALDÉS, 2001, p.37), não se constituindo simplesmente em línguas estrangeiras.

\subsubsection{Um caso específico de legislação}

Muito embora este trabalho não tivesse a intenção de levantar questões pertinentes à legislação, uma ocorrência específica nos chega por meio dos artigos jornalísticos e, dessa forma, por sua relevância, passa integrar esta análise. O exemplo vem do município de Blumenau que,no seu esforço pela promoção da língua alemã criou um conselho específico para deliberar sobre a questão. O que chama a atenção na legislação mencionada é a constituição de um conselho que parece representar as camadas mais afluentes da sociedade do município, sem que nos pareça haver muito espaço para a questão do dialeto que é presente na comunidade.

O Conselho Municipal de Língua Alemã foi criado pela Lei Complementar número 487 e sua constituição é um reflexo das atividades econômicas da localidade em um modelo que pode sugerir decisões de fora para dentro, ficando a participação efetiva das comunidades reduzida à 3 representantes (de um total de 22), da União Blumenauense das Associações de Moradores e ainda seria importante enfatizar que são representantes das associações e não necessariamente dos moradores.

Com a possível exceção do representante do Instituto de Investigação e Desenvolvimento em Política Lingüística, todos os demais integrantes parecem representar, direta ou indiretamente, interesses econômicos. Ainda, todos os integrantes parecem fazer 
parte da elite regional de Blumenau; talvez estejam um pouco distantes do falante de dialeto alemão. São pessoas comprometidas tanto com atividades que gozam de prestígio na sociedade como com os interesses econômicos na região de Blumenau, a saber:

Art. $3^{\circ}$. O Conselho Municipal do Ensino da Língua Alemã de Blumenau terá a seguinte composição:

I - três (03) representantes dos Professores de Língua Alemã, indicados pelo Secretário Municipal de Educação;

II - um (01) representante da Secretaria Municipal de Educação; III - um (01) representante da Secretaria Municipal de Turismo; IV - um (01) representante da Fundação Cultural de Blumenau; V - um (01) representante do Instituto de Investigação e Desenvolvimento em Política Lingüística; Moradores;

VI - três (03) representantes da União Blumenauense das Associações de VII - um (01) representante da Sociedade Cultural 25 de Julho; VIII - um (01) representante da Associação dos Clubes de Caça e Tiro de Blumenau; IX - um (01) representante da Associação Comercial e Industrial de Blumenau; $X$ - um (01) representante das Instituições de Ensino Superior; XI - um (01) representante da $4^{\mathrm{a}}$ Gerência Regional de Educação; XII - um (01) representante do Consulado Honorário da República Federal da Alemanha;

XIII - um (01) representante do Instituto Cultural Brasil-Alemanha; XIV - um (01) representante do Sínodo do Vale do Itajaí da Igreja Evangélica de Confissão Luterana no Brasil; Catarina;

XV - um (01) representante do Sindicato das Escolas Particulares de Santa

XVI - um (01) representante da Câmara de Dirigentes Lojistas; XVII - um (01) representante do Blumenau Convention Visitors Bureau; XVIII - um (01) representante da Associação das Micro e Pequenas Empresas de Blumenau - AMPE.

(BLUMENAU, 2004)

Blumenau abriga dialetos alemães; entre eles o pomerane, ou pomerish, e o próprio Hunsrückisch. As comunidades falantes desses variantes dialetais serão diretamente atingidas pela oferta do alemão padrão na escola pública, entretanto, não encontramos representantes dessas comunidades no conselho municipal formado exatamente para tratar do ensino da língua alemã.

No caso da comunidade falante de dialeto, o próprio dialeto é a língua imigrante dessa comunidade. Nesse contexto lingüístico pode não haver, na realidade, um imperativo interno que leve a um movimento de dentro para fora na direção da variante padrão. A presença de um elemento de interferência de fora para dentro, como a imposição da variante padrão, via sistema público de ensino, sobre essa comunidade pode interferir em um sistema que até então se encontrava em equilíbrio. 


\subsection{Análise das mensagens de internautas}

Prestemos atenção à mensagem sobre o assunto em que um internauta, usando o nome de usuário AcesHigh (EDUHAUS et ali, 2005)), na comunidade virtual Skycrapercity Forums, expressa sua opinião sobre a situação do alemão no Estado do Rio Grande do Sul. Pela resposta de EduHaus (EDUHAUS et ali, 2005), percebe-se que para um a existência do dialeto é um fato, apesar da equiparação com o "o alemão". Para AcesHigh (EDUHAUS et ali, 2005), no entanto, a questão parece mais de letramento em língua alemã e encerra uma hierarquia onde aqueles que não sabem ler ou escrever, que é o caso dos falantes de dialetos, vem depois dos "alguns" que "o sabem fazer em alemão"

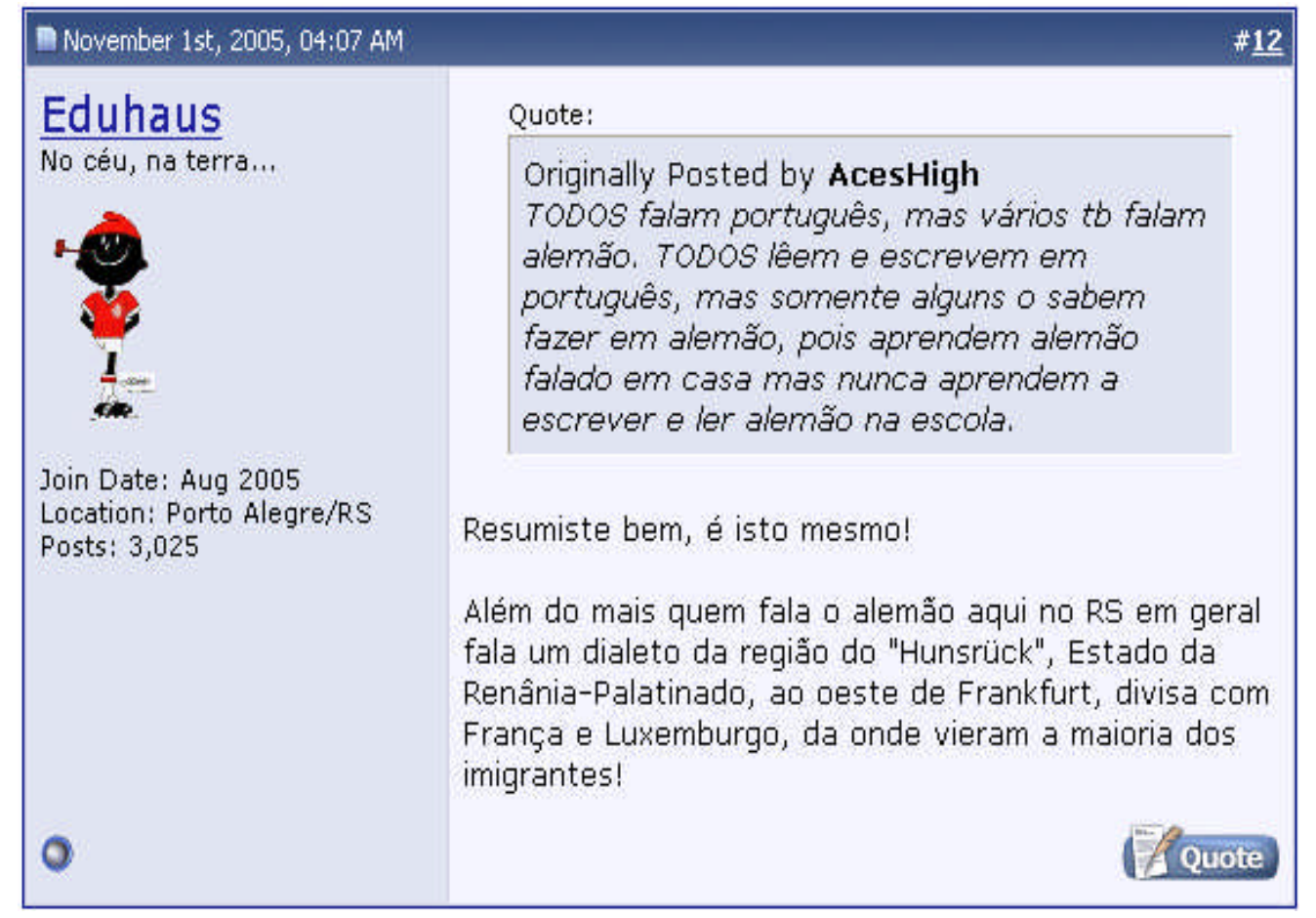

Figura 3 - Diversos falantes

Aqui ainda nos deparamos com a realidade da consciência da existência de um continuum de bilingüismo de que nos fala Valdés (2001, p. 40.), um conceito de grande importância e com impacto sobre a maneira como esses diferentes falantes citados por AcesHigh devem ser atendidos de formas diferentes, como já visto em 3.4.

As mensagens também são úteis para nossa compreensão das atitudes lingüísticas. $\mathrm{O}$ internauta Schmidt (EDUHAUS et ali, 2005) sobre a situação em Blumenau, reforça a percepção de que os mais jovens tendem ao abandono da língua que sobrevive falada pelos mais velhos. A mesma mensagem reforça a queixa de Oliveira (2008) sobre o abandono da 
língua, ao mesmo tempo em que impõe o questionamento sobre a obrigatoriedade de ensinar algo que uma comunidade possa ter escolhido abandonar. Será a imposição da língua imigrante capaz de reverter o desejo de abandono no caso de sua existência?

\section{Português "urbano" e alemão "arcaico"}

"O português passou a ser símbolo da cidade, das camadas mais altas da população, do saber, da escola e de uma geração mais jovem. O Hunsrückisch ficou associado às zonas rurais, à origem, à família, à solidariedade entre os grupos e às gerações mais velhas", descreve Cléo Altenhofen o processo de "lusitanização das novas gerações" em determinadas comunidades do Rio Grande do Sul.

O respeito à língua - transmitida de geração a geração, mesmo quase dois séculos após a chegada dos primeiros imigrantes - é uma prova do caráter de "ilha lingüística" (Sprachinsel) das colônias alemãs na região Sul do Brasil.

(VILELA, 2004)

$\mathrm{Na}$ medida em que a língua herdada passe a representar um modo de vida ultrapassado, pouco poderá ser feito para reverter-se este quadro, mas reconhecemos que um esforço de fora para dentro talvez represente a única forma de reverter o quadro e revitalizar essas línguas dentro das comunidades.

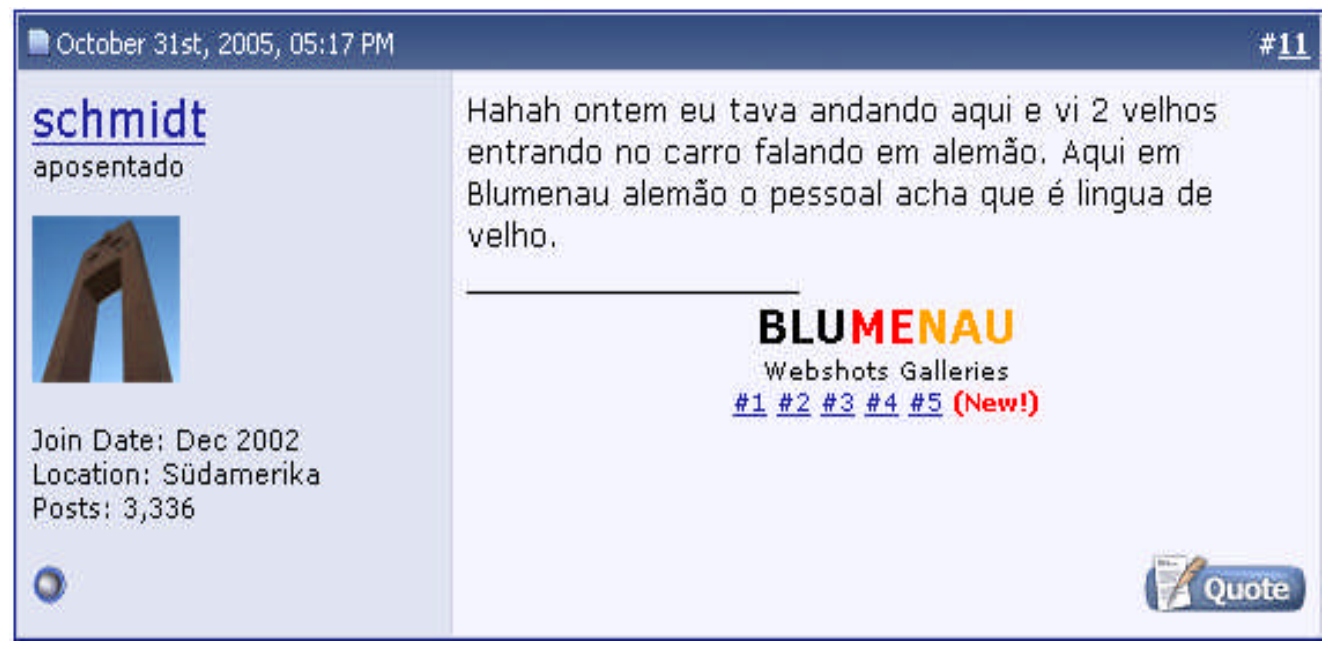

Figura 4 - Língua de "velho"

Tal reversão, no entanto, está sendo freqüentemente associada, como fica claro pelos artigos analisados, à melhores chances no mercado de trabalho que podem servir de atrativo para os mais jovens. 


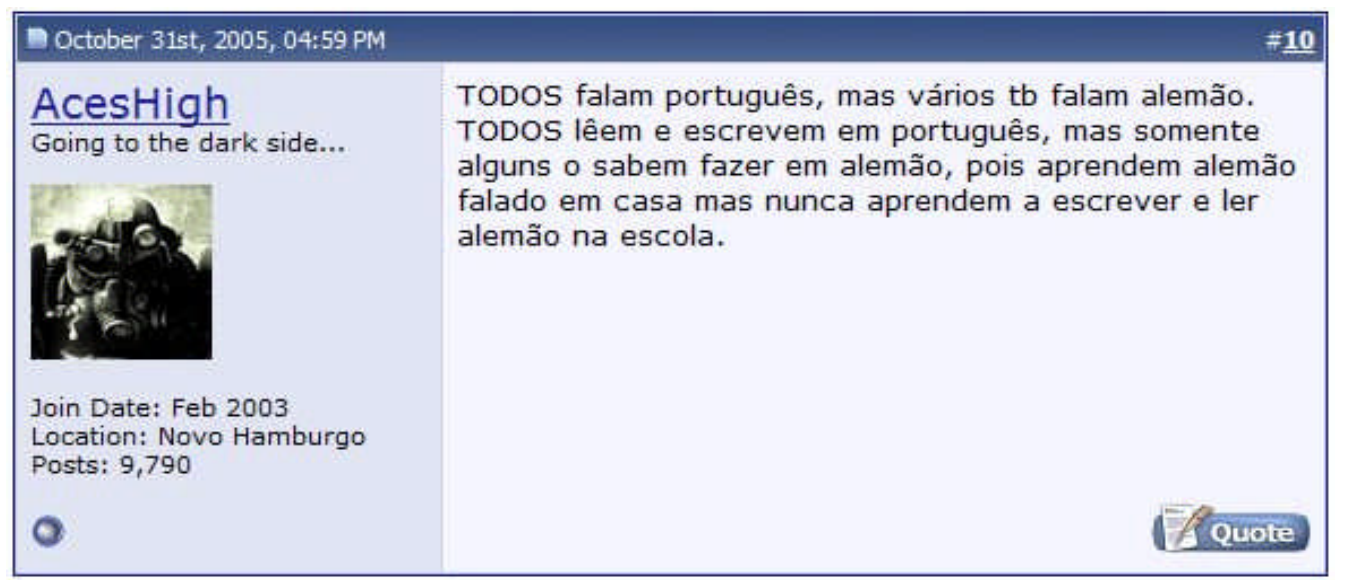

Figura 5 - Oralidade

A existência da mensagem transcrita acima, do internauta com nome de usuário Aceshigh e, conforme informações constantes do próprio tópico de discussão, morador de Novo Hamburgo, no Vale do Rio dos Sinos, região de ascendência predominantemente germânica demonstra que a compreensão da complexidade do tema não está fora do alcance do cidadão que compreende a natureza do contexto lingüístico.

As próximas mensagens relatam a história de um deputado que viaja para a Alemanha e consegue, falando Hunsrückisch, comunicar-se perfeitamente em uma região, mas não em outra, segundo um dos internautas. 


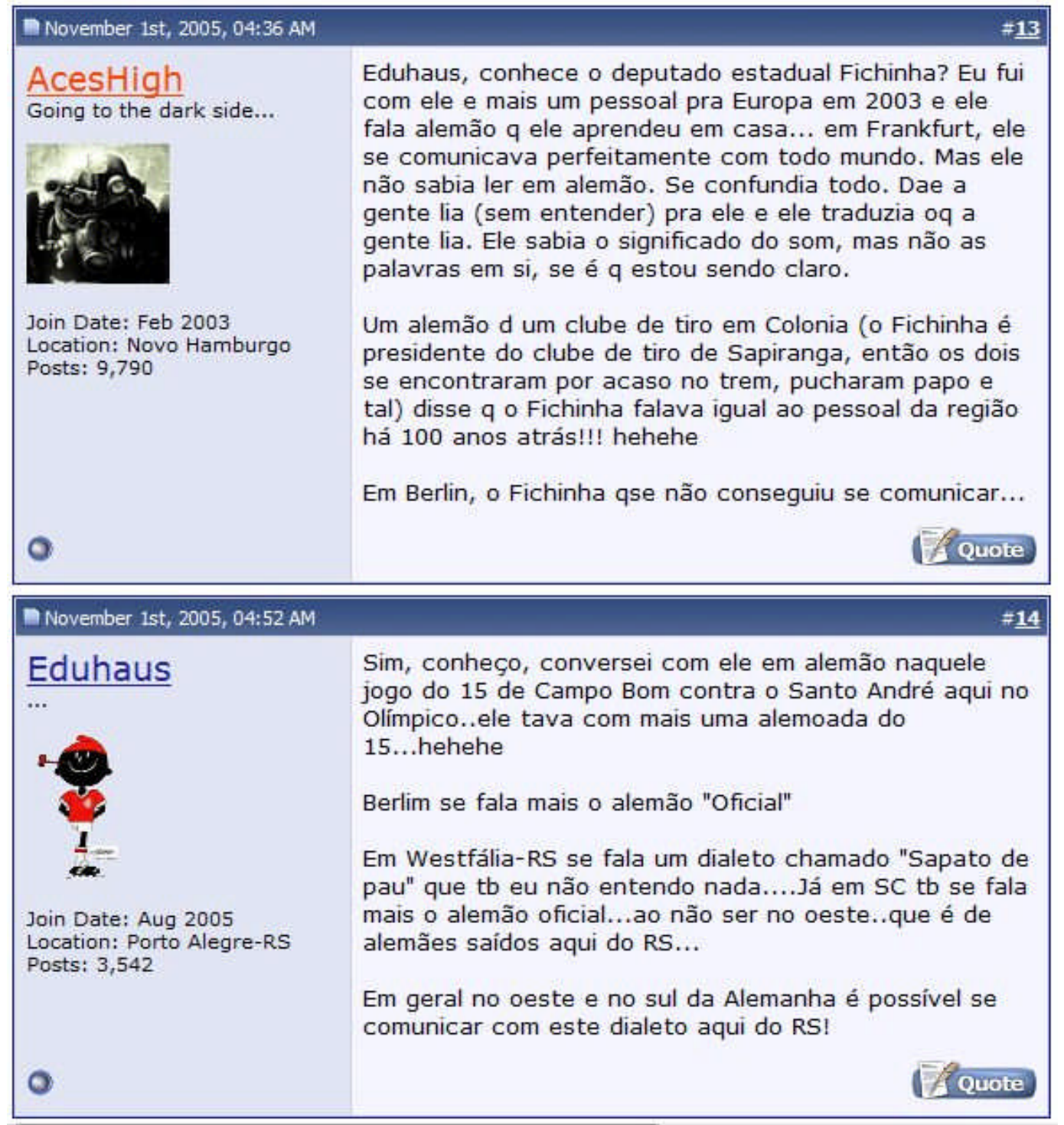

Figura 6 - Dialetos

Determinar se o alemão do deputado, de fato, soa como o alemão de 100 anos atrás nos parece difícil, em face da quase impossibilidade de sabermos como era realmente falada a língua naquele tempo. Mesmo diante de gravações antigas, teríamos o filtro da tecnologia e do comportamento diante dessa tecnologia como fatores de interferência nessa reconstrução. Mas ainda que isso fosse verdade, tal fato só reforçaria o valor da preservação desse dialeto tanto por seu valor histórico como lingüístico.

Essa percepção sobre o modo de falar antiquado do deputado nos parece poder resultar de uma projeção por parte do interlocutor, a partir de informações obtidas do próprio falante da variante dita "arcaica", ou a partir de percepções preexistentes com relação a essas variantes. 
Também é preciso compreender-se a natureza dinâmica da língua e que esta existe, na realidade, não de forma estanque, internalizada e rígida, dentro do indivíduo, mas se manifesta na interação entre os falantes. Supor que esses indivíduos que se encontraram em um trem, apenas por alguns minutos, não possam ajustar e renegociar o contrato de comunicação permitido pela língua partilhada seria equivalente a supor que um gaúcho não pudesse se comunicar com um nortista. Ao longo de um período de tempo essas possíveis diferenças tendem a ser resolvidas em um processo adaptativo por conta de tratar-se da mesma língua; o que não parece ter ocorrido com o deputado em Berlin, onde a língua já não é partilhada - segundo o relato do internauta que teria viajado com o deputado. 


\section{CAPÍTUlO 5 - ANÁliSE DE ENTREVISTAS}

Sobre o tratamento das entrevistas, é importante explicar que foram utilizados métodos diferentes para a entrevista inicial e para as demais que se seguiram.

Para a primeira, julgamos justificado o uso de uma transcriação, nos moldes propostos pela disciplina de História Oral, para que o leitor possa perceber com mais facilidade um conteúdo que fica diluído na transcrição convencional. É importante lembrar que, embora se tenha buscado manter na transcriação o tom e certas peculiaridades presentes nas falas originais, a transcriação consiste em interferência do entrevistador e não servirá como base para a análise que será feita com base em uma transcrição convencional cujos trechos relevantes integram o corpo deste trabalho.

Para as demais entrevistas, optamos pelo uso de transcrições parciais que também integram o corpo deste texto.

É importante salientar que as citações de trechos transcritos tendem a ser mais longas em função da necessidade de contextualização e da realidade inerente à construção do diálogo entre entrevistador e entrevistado, onde conteúdos ficam freqüentemente diluídos ao longo de várias falas.

\subsection{Transcriação da entrevista com Zilma Seidler}

\section{Zilma Seidler, Dia 5 de Janeiro de 2007, Município de Balneário Camburiú, SC}

Meu nome é Zilma Seidler e eu nasci em Angelina, uma colônia de alemães, no dia 31 de julho de 1964; até ir pra escola eu só usava alemão; eu lembro que a gente ia pra escola e ia falar na escola em português, e quando chegava em casa falava tudo em alemão de novo. Angelina é município de Santa Catarina e a minha língua materna é alemão - no meu caso um dialeto de alemão que eu nem sei como surgiu; não sei como viemos parar aqui.

Eu acho que foi o bisavô do meu pai; mas nunca contaram; também nunca perguntei direito sobre a história de como tudo foi. Eu devia ter perguntado para os meus pais que sabem mais da história, mas nunca me interessei de perguntar. A geração do meu tataravô foi a primeira a chegar ao Brasil e eu faço parte da terceira geração de brasileiros e fui educada só em alemão.

Quando a gente era pequeninha lá na colônia em Angelina, que era muito... muito pobre no caso. De quando eu nasci até uns $5 \ldots 6 \ldots$ até os 8 anos, não tinha nem luz; a gente tinha aquela luzinha de querosene. De noite, a gente fazia tudo no escuro. Não tinha nem estrada; não tinha nada... Quando eu era pequeninha, a gente ia pra escola a pé e eu, quando chegava, até trabalhava na roça. Acho que foi por volta de quando eu tinha uns $10 \ldots 12$ anos que já começou a vir a estrada e começou a passar carro. Naquela época, quando eu nasci, 
era meu pai que plantava e colhia e criava os bichos; tudo aquilo para a gente ir se virando. De manhã comprava açúcar e as coisas que tinha a venda; tudo que a gente podia comprar que não tinha como a gente fazer. Mas tinha até gente que plantava cana e fazia açúcar e tudo. $\mathrm{A}$ gente fazia açúcar de cana... fazia melado... coisas assim... Mas não era todo mundo que fazia. Os que já eram um pouquinho melhores tinham as máquinas para fazer o melado e 0 açúcar... tudo na verdade. Meu pai fazia farinha; ele tinha engenho de farinha a gente fazia farinha... fazia polvilho... a gente fazia rosca... aquelas coisas todas... fazia tudo no engenho dele. Às vezes, a gente fazia mais pra tentar vender... pra ganhar um dinheirinho, pra comprar aquilo que faltava e que a gente não plantava. No caso, açúcar... café... A gente tinha cavalo... tinha boi... tinha as carroças que levavam até as vendas para poder vender. Essas comunidades já eram fora; só que elas tinham as vendinhas para tentar ajudar as pessoas a ter como comprar as coisas que não dava para plantar e colher para não faltarem. Elas ficavam a umas duas horas de cavalo ou de boi até chegar lá e tentar fazer as compras. Era longinho e só se usava alemão... nada mais. Nunca aprendi português até os sete anos... aí a gente foi pra escola. Eu tinha muito medo de ir pra escola. Mas a gente tinha que ir, né? O pai brigava pra gente ir: "vocês vão... vocês têm que aprender a ler, escrever" nós fomos, mas a gente tinha muito medo de ir pra escola. Era uma coisa assim: a gente tinha que ir a pé, era uma meia hora para ir a pé até chegar na escola, a gente ia descalço, todos, de chinelinho. Aí a gente chegava lá. A professora era muito braba. Ela, às vezes, quando a gente não sabia as coisas direito, botava a gente de castigo e alguém ficava de joelhos quando não fazia as coisas direito... ela era muito braba. Esse tipo de castigo ainda acontecia na área rural e ela chegava, às vezes, a torcer a orelha da gente... chegava a machucar a gente. A disciplina era muito... muito rígida, mas o medo também atrapalhava muito o aprendizado porque a professora era muito rígida, muito braba, ela tinha até uma varinha na sala de aula, se ela chegasse lá e visse que nossa letra não tava correta... que tava meio torta... ela batia no dedo da gente e dizia: "Pode apagar tudo, pode fazer tudo de novo". Às vezes, a gente não entendia o que ela falava, e ela sabia falar as duas línguas. Aí ela falava em alemão pra gente entender o que ela estava falando. Ela tinha que saber falar as duas línguas porque a gente não sabia. A aula era em português, mas se a gente não entendesse a professora falava em alemão e começava de novo. Aí através de ir pra aula a gente ia aprendendo as duas línguas no caso. A professora era de fora... ela vinha todos os dias da cidade... Angelina. Eu morava no interior e ela já morava na cidade. Ela era parte da comunidade, mas só que ela não era alemã mesmo, ela já era brasileira no caso. Só que ela sabia falar em alemão... que precisava... porque como é que ela ia ensinar os alunos sem saber se eles não estavam entendendo nada... se não iam se perder. Mas o alemão dela era diferente e a gente tentava adivinhar o que ela dizia... tentava acertar. Aí, se tu não acertava, tu ficava quieto e aí ficava aquilo mesmo pra não ficar de castigo ou uma coisa assim... que ela era muito braba, muito rígida. Se tu não entendia ela... qualquer coisa... ela botava a gente de castigo... em cima do sal, no caso, de joelho. Ela era muito braba...quantas vezes...aí tu tinha que ficar de joelho mesmo, não podia nem se abaixar porque ela ficava do ladinho.

A turma era, mais ou menos, uns vinte alunos. Mas ela pegava $1^{a}$. Série, $2^{a}$. Série, e a $4^{a}$. Série junto na mesma sala; falando com todo mundo junto eram mais ou menos umas vinte crianças na sala de aula. Eram séries diferentes, mas era tudo na mesma sala. Eles só se preocupavam em alfabetizar em português... em alemão não. Alemão não aprendi. Não tinha professor que ensinasse a gente, que ensinasse a escrever em alemão. Porque ela era brasileira, no caso, só que aí não deu para nos ensinar. A minha mãe ainda sabe, sabia ler e escrever em alemão, mas eu não tive esta oportunidade. Eu só falo. A minha mãe sabe ler e escrever tudo em alemão... eu já não. Uma pena porque hoje em dia eu sei o quanto é importante a pessoa saber ler e escrever em alemão. Só que eu não aprendi porque minha geração já é muita geração, né? 
Os pais da gente eram muito rígidos, muito brabos e a gente não tinha coragem de perguntar nada pros pais e ficava guardando aquilo pra gente mesmo: por que é que o alemão que a gente falava em casa era diferente do alemão da professora da escola? E eu tinha curiosidade de saber, mas o respeito e o medo eram muito grandes e a gente não perguntava muitas coisas pros pais; a gente tinha curiosidade de perguntar tudo, mas o meu pai era muito autoritário... muito brabo. Não podia fazer nada errado; era tudo certinho e então tinha coisas que a gente tinha vontade de perguntar e tudo, mas nunca falaram sobre nada... .sobre sexo... sobre nada. Quando chegava a época de ficar mocinha, a gente não sabia de nada; era tudo muito escondido. A gente foi criado diferente assim...

Eu me perguntava e tinha curiosidade sobre o alemão da professora e as outras crianças também. A gente tinha que falar português. Forçava a gente aprender... ninguém podia falar em alemão na hora da sala e se alguém falasse em alemão ela fazia "Psiu" e tinha que ficar quietinho; existia uma repressão. Mas tinha "brasileiro" na sala de aula também. Enquanto eu tava na minha $2^{a}$. Série, lá chegou um casal mais de fora. Vieram morar mais próximo do colégio onde eu estudava e eles tinham dois menininhos e uma menina; só que os meninos eram tão moleques... tão rebeldes... que eles sabiam que a gente tinha medo sei lá de que... eles discriminavam a gente na sala de aula... fora eles falavam...avacalhavam com a gente... roubavam a mochila da gente. "Seus alemão!", eles xingavam a gente e a gente tinha medo deles, engraçado... tinha medo deles. Medo de crianças. São só dois que vem para a nossa escola avacalhar a gente. Chegavam até a roubar a minha mochilinha; quantas vezes eu chorei e eles só rindo. Não sei de onde surgiram aquelas crianças, mas acho que eles viam como a gente era criado daquele jeito tenso, naquele medo, fazendo tudo certinho. Eles tinham até um negócio... um tipo de uma armazinha... um revolverzinho e eles começavam , "eu vou matar vocês" e nós saíamos gritando de tanto medo deles. Até a época quando os pais se revoltaram e não aceitaram mais eles na escola porque não estava certo e até se mudaram e foram não sei pra onde...

A gente falava alemão escondidinho... no recreio. Ah, no recreio, sim, no recreio a gente brincava... falava tudo em alemão na hora do recreio Foi aí que começou o conflito porque a gente falava em alemão e eles não. Daí como ninguém se entendia, eles se sentiam... eu acho, olhando hoje para isso... que talvez eles se sentiam muito atingidos, só os dois sozinhos e foi aí que eles começaram, vendo que a gente tinha mais medo, que as coisas pra gente eram mais rígidas e que eles podiam dominar a gente. Exploraram a situação... só que a gente tinha medo.

Não sei se o fato da professora falar alemão era coincidência; acho que eles sempre procuravam uma professora que sabia as duas línguas porque alguém que não soubesse falar as duas línguas não teria como ensinar as crianças se não entendesse o que elas diziam. Era muito difícil conseguir uma professora lá; por isso que só tinha uma e ela era muito braba. Então ela dominava porque era só ela; por isso que as crianças apanhavam muito na época dela...

Para os meus pais o alemão da escola não era o mesmo. Eles comentavam, às vezes, que era diferente... que o deles era melhor do que o nosso. Mais forte, melhor... nunca 0 contrário. Eles achavam que o alemão deles, como meu pai dizia, era "mais alto". A gente foi aprendendo esta palavrinha: "mais alto" O nosso é mais pequeno; ele falava que era dialeto, mas na cabeça dele a gente já pensava diferente. Nosso dialeto não tem nome, se chama simplesmente de dialeto... dialeto da região de Angelina.

Naquela época não tinha dentista... não tinha nada na época dos meus pais. Todos sofriam muito com dor de dente e tudo porque não tinha ninguém pra atender a eles lá. Eles perdiam os dentes; todos eram muito judiados, sofriam muito. Meus avós daí chegava no ponto... todo mundo sofria... não tinha condições... não tinha como... não tinha recurso... mas a comunidade foi indo... foi crescendo... Também não tinha médico quando os pais ou algum 
parente ficava doente. Teve uma vez que a minha mãe ficou muito doente e teve a minha vó também. Que é que a gente fazia? Pegava dois paus, um de cada lado para conseguir levar eles pra um hospital mais próximo... que não tinha estrada... não tinha nada naquela época. Aí pegava dois paus, um de cada lado, amarrava um lençol e quatro pessoas levavam a pessoa doente até conseguir pegar um carro pra levar mais longe. Era muito... muito cruel, muito sofrido naquela época da minha vó... da minha mãe. A minha mãe ficou uma vez porque não tinha estrada de chão... aí levava três horas até chegar no hospital... a gente não tinha carro... Até, às vezes, vinha uma pessoa que fazia remédio caseiro que chegava lá, mas, às vezes também não tinha recurso, aí tentava levar até Florianópolis, mas até chegar lá demorava muito...

É uma pena que eu não tenha aprendido a escrever em alemão... O meu filho está entrando pra escola... ele foi anteontem visitar a escola; as aulas já começaram, mas vou deixar ele ainda um mês antes de levar na escola aqui perto. 0 Juan não fala alemão; não recebeu o alemão. Mas quem sabe, eu vou ensinar porque é uma coisa que ele vai aproveitar muito se ele aprender... porque ele tem vontade de aprender também, mas é meio complicado ensinar sozinha porque se está tão acostumado a falar português que é difícil tu falar... eu me pergunto 0 que poderia ter sido diferente para que ele falasse alemão. Eu deveria, quando chegam as férias, mandar ele para a casa dos meus pais. Cometi o mesmo erro com a minha filha que é casada e tudo... Devia deixar lá uns dois... três meses... lá no meio pra aprender a falar e conviver só com alemão, mas eu não fiz isso. Acho que seria mais fácil porque daí todos conviviam juntos e aprendiam porque tu falar sozinho, sem todo mundo junto, é difícil de pegar... falar mesmo, como eu aprendi, porque é muita coisa... tu conversando... o alemão não é uma língua muito fácil de falar.

Eu acho muito interessante, eu acho muito bom que ensinem alemão culto para as crianças que estão na escola, mas é difícil aprender a língua fora do contexto. Mas para aprender não é suficiente. Acho que não é suficiente porque aprende muito pouco porque é muito pouco tempo e porque é muito pra tu aprender... se tu tem que conviver o que tu aprende... passa pra tu te virar, mas falar em alemão mesmo vai ser muito complicado. O meu alemão eu recebi da minha família porque foi anos e anos falando, mas a gente sabe conversar normalmente... conversando, falando tudo. Tenho muitas amigas que até estão fazendo o alemão de Balneário; uma está há dois anos fazendo curso e ela não aprendeu a falar em alemão ainda por que é difícil... com curso específico de alemão. Ela está estudando há dois anos e fala bem pouco... ainda é difícil para uma pessoa... é uma língua muito difícil. Talvez ela venha aqui; vou ligar para ela ver se ela vai vim aqui porque amanhã é aniversário do Juan. Ela está na aula de alemão há quase dois anos e não aprendeu quase nada. Ela aprende lá dentro, mas para ela chegar a se virar... ela quer ir para a Alemanha então ela está tentando há dois anos para poder sair daqui e chegar na Alemanha. Ainda é muito difícil para a pessoa aprender a falar mesmo sem ter o convívio. Eu acho que a minha experiência... que eu tinha 0 mesmo problema porque o português pra mim foi difícil também... tem coisas que às vezes eu me atrapalho para falar tudo... tem coisas que a própria língua às vezes não consegue falar a palavra... é meio difícil.

Isso aí foi interessante eles acharam legal; a partir disto que a gente aprendia na escola, a gente foi passando pros pais... aí a gente foi ensinando tudo que a gente aprendia já pra eles... aí eles começaram com o que a gente sabia falar. A gente falava com eles, ensinando e eles também começavam a aprender também; só que a minha vó que já morreu nunca falou uma palavra em português, mas os meus pais já aprenderam a falar em português através da gente que ia pra escola, eu e meus irmãos continuamos levando tudo pra casa e nossos pais conseguiram aprender um pouco a língua pra poderem se virar se saíssem fora daqui. Eles começam a falar português quando a gente vai para a escola... a gente trouxe 0 português para dentro de casa. 
Meu pai faleceu faz três anos; a minha mãe ainda está viva; o meu pai conseguiu se virar e depois com anos tentou se interessar também... conseguiram se virar e eu vim pra Florianópolis pra depois estudar. Aí eles vinham visitar a gente eles se interessavam em aprender e, cada vez que vieram pra me visitar, eles foram aprendendo mais coisas e eles conseguiram falar em português também. Agora a mãe mora lá perto da praça. Lá mora bastante brasileiro, como a gente diz, ela já ta se virando bem hoje em dia também, se ela sair, ela não se perde mais também... já consegue se virar também só tem umas irmãs minhas e, dos meus irmãos, tem uns dois que mal se viram em português; eles ainda moram na colônia. Pra continuar o alemão... Eu acho que os alemães se sentem tão envergonhados... que ninguém quer levar mais adiante. Hoje em dia eu vejo que é muito importante, mas quem mora lá não quer... Não queria ser alemã. Em Angelina porque eles se sentem meio discriminados, "aqueles alemão, lá... não sei o quê", não simpatizam muito. Então quem pode sair de lá e tentar ter uma vida melhor quer seguir outro caminho, não quer seguir mais o alemão. Eu me sentia assim também porque a gente é alemã, não sei porque, eu também tinha isso. Eu nasci no Brasil, mas a gente se identifica como alemã porque fomos criados assim; mas na verdade, como muitos, não era só eu que não queria ser alemã, queria ser filha do outro, não queria ter nascido lá porque a gente se sentia muito... Sabe que eu não sei dar a explicação pra isso mas a gente se sente... É um sentimento que a gente tem para o qual eu não tenho nem explicação.

0 meu pai teria agora 65 e a mãe está com 69; eram criança na época da segunda guerra quando houve uma repressão muito forte contra os alemães e acho que, por causa disso, eles tinham sofrido muito, mas não sei porque não peguei aquela época e eles contavam, mas não sei bem da história... mas dizem que os alemães foram muito discriminados e aquela história foi sendo contada e por isso ninguém queria ser mais alemão... não queria ser filho de alemão. A gente, às vezes, tinha vergonha de conversar, a gente tinha muita vergonha... dependendo do lugar a gente já ficava quietinho, nem falava, a gente ficava encolhidinho, não falava nada, dependendo do lugar, a gente a gente se sentia meio assim " não, não pode falar", mas porque não era sabido. Era assim: "Não pode." Mas a gente não sabia porque aquilo também era escondido; ninguém dava explicação pra gente. A gente tinha medo de falar alemão. Tinha medo; era muito medo; a gente foi criado com muito medo... mas sem saber medo de quê. A comunidade ainda existe e ainda existem famílias assim que só falam alemão em casa. A situação da escola mudou...mudou muito... hoje em dia, já tem estrada... não é mais como naquela época quando eu vivia lá. Todo mundo já tem televisão, tem luz, tem banheiro... na minha época não tinha banheiro... não tinha nada ali... era tudo através de gamela até para tomar banho... não tinha chuveiro, não tinha nada... nem conhecia chuveiro, banheiro, nem nada na minha infância... mas hoje em dia já têm casas com luz, tudo com banheiro. As escolas é tudo diferente com banheiro e com tudo. As professoras são outras nem tem mais as da minha época. Tudo foi mudando; até as crianças estão vendo televisão; estão vendo tudo e já aprendem. Na minha época era tudo diferente; muita coisa da minha época não existe mais.

Quando aprendi alemão da minha família (não existia televisão, não tinha nem rádio... nada. Hoje a criança já nasce assistindo TV, exposta ao português dentro de casa, já está aprendendo; na minha época era muito rígido... peguei uma época muito ruim; agora já tem estrada que tem ônibus que passa e pega as crianças pra levar na escola. Na minha época não tinha nada disso... melhorou muito. Mas eu acho que, hoje em dia, a professora não fala alemão; já deve ser só em português, eu acho, não tenho certeza, mas pelo que eu sei, quando meus irmãos foram, já tinha aula até a noite; na minha época era só até a quarta série e depois acabava e tinha que estudar fora, mas agora, já tem professores que dão aula à noite lá, já tem até a $8^{a}$. E já tem outros professores que não falam mais em alemão. Tudo é mais fácil para eles... todo mundo tem uma vida mais fácil. Mas as crianças, em casa, continuam só falando tudo em alemão. Eu tenho uma irmã que mora aqui perto de Florianópolis, aqui em 
Biguaçu e ela ensina os filhos dela em casa... tudo em alemão pra quando sai aí. Há famílias onde as crianças ainda recebem o alemão como língua materna e outras onde não mais porque começa a mistura, às vezes do marido de fora, como é o meu caso que saí fora e casei com "brasileiro" e que, como meu pai dizia, "sujou a família". Meu pai nunca aceitou que eu sujei a família; meu pai queria que eu casasse com "alemão", mas eu acho que sempre fui a filha mais rebelde da casa; sempre quis sair e quando consegui sair para estudar, conheci um cara e me apaixonei, comecei a namorar e acabei ficando grávida, mas eu não cheguei nem a casar. Aí começou a discriminação... não podia mais ir para a casa porque tinha ficado grávida e, ainda por cima, de alguém de fora. Aí se quebra o vínculo porque eu sempre me senti meio discriminada e não queria ser igual a eles; eu queria ser diferente e conseguir sair de casa. Isso meu pai nunca aceitou, mas peguei e consegui sair e quando eu trabalhava eu tinha que mandar metade do meu salário para casa. Eu já mandava o dinheiro antes de engravidar... eu trabalhava e estudava e aí eu mandava a metade até quando eu tinha uns 17 ou 18 anos; aí conheci um rapaz e engravidei quando eu tinha de 19 para 20. Eu tenho uma menina... uma filha grande, casada. E assim começou o conflito com o meu pai. E a minha filha não aprendeu alemão. Com o tempo, o meu pai entendeu; a gente foi lá e explicou tudo.

Aí ele se arrependeu e disse, "não, já que aconteceu, arranjou uma filha, é minha neta."; ele também veio atrás... veio falar comigo... veio conhecer a neta. Aí depois que ele conheceu a neta ele aceitou e a gente podia ir lá visitar ele e tudo. Depois de ela nascer, ela tinha um mês de idade quando ele veio conhecer e disse que a gente podia ir e tal e a família voltou ao normal. Só que a minha filha não aprendeu a falar em alemão e quando ela ia pra lá comigo ela se sentia perdida... ela nunca gostava de visitar os avós porque eu falava em alemão com eles... e todo mundo falava em alemão e ninguém falava com ela que ficava no meio sem entender nada do que estava rolando. Ela se sentia perdida e era ruim pra ela. Hoje em dia, eu entendo como era ruim pra ela. Quando chegavam as férias e era para ela ficar lá uma semana, ela dizia, "mas eu não gosto de ficar lá... eu não entendo nada que eles falam... fico lá perdida" a gente falava só em alemão e ela ficava sozinha. Aí, às vezes, quando ela queria uma coisa, eu falava com ela em português porque ela só falava em português. Por conta do casamento, tu precisa se comunicar com um brasileiro, em português, e acaba não transmitindo a língua para os filhos. Se os dois forem da comunidade fica mais fácil. Nas famílias que casam dentro da comunidade... isso é mais fácil e é por isso que eles não aceitavam casar fora com quem não soubesse alemão. Ainda que fosse alemão, se não soubesse falar alemão já não servia. Acho que tinham mesmo a intenção de preservar, mas eu mesma era uma pessoa que não entendia; eu já quis acabar com a colônia. Há pessoas que querem e pessoas que não querem preservar esse modo de vida. Mas ainda é difícil encontrar o "alemão" que casa com alguém que não seja "alemã". Então as minhas primas e as minhas sobrinhas continuam se casando com "alemão" mesmo... da própria região... lá perto. Para não dizer que não tem ninguém, a única de quem eu lembro fui eu... que casei fora... naquela região toda e por ter casado com "brasileiro" fui muito discriminada naquela colônia; quando minha filha nasceu eu não ia lá ... não ia a lugar nenhum porque todo mundo me olhava e falava de mim, " foi essa aí que sujou a família, sujou nossa...". Eles usam essa palavra. Aí tu ia lá e se sentia tão mal porque todo mundo te olhava daquela maneira... discriminavam assim, "sujou a família, sujou nossa região aqui em volta". Mas, hoje em dia, já vejo tudo diferente... não é mais como na minha época. Isso faz 20 e poucos anos e era bem rígido; hoje em dia já não é mais, mas mesmo assim, até hoje, continua casando "alemão" com "alemão". Mesmo hoje em dia, todos os meus irmãos se casaram com "alemães"; não tem mistura nenhuma, tem até uma irmã minha que casou com um segundo primo porque não tem com quem casar; 0 lugar é muito pequeno e, no final, acabam se apaixonando uns pelo outros e acabam casando até sendo meio parentes. $O$ filhos deles falam tudo em alemão... tudo. A escola tem um papel 
para ensinar a ler e a escrever... deveria alfabetizar e auxiliar no processo de alfabetização de quem já tem a língua.

Como eu disse, eu estudei lá até a $4^{a}$. Série e depois fui para Florianópolis porque queria estudar mais e tinha uma senhora precisando de alguém para tomar conta das crianças e fui embora; fui ser babá e cuidava de criança durante o dia e à noite eu ia pra escola lá em Florianópolis e fui continuando os meus estudos, mas não cheguei a fazer o segundo grau por que eu comecei a namorar e comecei, como se diz, a relaxar e me apaixonei e nem cheguei a fazer o segundo grau; mas estudei até a oitava série. Depois eu casei e fiquei mais em casa com o marido... ele tinha negócio de automóveis e eu ficava em casa só cuidando da casa e do marido... cuidando só dentro de casa. Mas meu casamento não deu certo... durou seis anos e depois me separei; aí fiquei separada acho que uns cinco... seis anos e continuei fazendo um cursinho. Depois trabalhei numa escolinha... numa creche cuidando de criança e depois eu conheci o Valdir. O Valdir já tinha o negócio de mercado dele também nós nos acertamos e casamos; já faz onze anos... a gente agora vive só de renda. Minha história é essa.

0 que poderia ter sido diferente? Eu errei minha vida toda... eu não devia ter namorado. Devia ter continuado meus estudos... podia ser alguém hoje... queria ser quem não sou... sempre tive vontade de ser uma doutora ou o que fosse uma coisa de ter um diploma... uma coisa pra continuar... que tinha vontade de fazer e que não fiz porque me deslumbrei. Porque meu pai era muito rígido, quando vim pra cidade, quando me senti solta, quando não tinha ninguém pra me prender, acabei não seguindo meus estudos, acabei engravidando, tendo filho e depois não voltei mais pra estudar... mas eu queria que minha vida fosse bem diferente , mas... eu me arrependo de não ter estudado. Falo sempre pra minha filha, que vai fazer 23 anos este ano, "não faz aquilo que eu fiz; tenta fazer uma faculdade", só que ela também casou nova e não está fazendo a faculdade. Tinha vontade de ser uma doutora, mas casou e está lá com a minha netinha... com filho... e sem estudo a gente não consegue nada e ela não aprendeu alemão. Eu acredito que se ela tivesse aprendido alemão em casa ela estaria numa situação melhor. Teria mais incentivo para tentar aprender mais uma língua... um alemão correto... que ela não sabe que é diferente, mas seria mais fácil pra ela aprender o que falta e corrigir os erros que tem no alemão da gente. $E$ ela me cobra muito isso... que eu não ensinei, mas pra mim era difícil pra ensinar ela também. Eu acho o dialeto um alemão errado porque eu conversei com uns casais que vieram aqui na praia, que vieram da Alemanha, dois casais com os quais consegui me comunicar... mas, esses dias, veio um outro casal eu não consegui me comunicar com eles e então acredito que tem dois "alemão"; tem um dialeto e tem um outro. $\mathrm{O}$ alemão de quem estuda 0 alemão na escola fica diferente... completamente. Tem um tio meu que aprendeu a falar o alemão correto. Quando ele vai lá na casa da mãe ele diz "não, eu sei falar alemão correto"; ele é diferente também, mas a gente... a mãe consegue entender ele... mas é completamente diferente... ele acredita que o alemão dele é o certo. Mas eu acredito que é o certo mesmo. Porque parece que ele fez aqui em Balneário, nem sei bem onde ele mora; mas ele sabe falar alemão correto; ele sempre teve o sonho de ir pra Alemanha, por isso ele estudou; mas até hoje ele ainda não foi porque precisa de um monte de dinheiro; não adianta você ir lá com pouco dinheiro, por causa disso ele não foi ainda.

Ainda bem que aquela época já passou porque a minha época era muito difícil; coitados dos meus avós... A gente tinha uma igreja que era igreja "dos alemão", que o nome da igreja protestante era... o culto era todo em alemão. O pastor vinha, geralmente uma vez por mês ele dava culto pra gente; nesse dia, a gente ia todo mundo. Todo mundo se arrumava, geralmente era um domingo de manhã porque durante a semana todo mundo trabalhava... ele ia fazer domingo de manhã... aquilo pra nós era uma festa. A gente gostava de ir à igreja; todo mundo ia para igreja naquela alegria e todo mundo se arrumava naquela época. Era um passeio para a gente. Para nós até não era tão longe, era uma meia hora à pé, mas tinha gente que vinha de mais uma hora de distância... à pé... a gente não tinha carro; ninguém tinha 
carro. A gente ia de chinelo porque a estrada era de lama e quando chegava perto da igreja lavava os pés e botava o sapato (risos) para ir pra igreja bonitinho, pra todo mundo ficar bonitinho lá na hora da igreja, engraçado... aí a gente ficava na igreja... depois da igreja, e depois, na hora de ir embora, tirava o sapato... tudo de novo e ia de chinelinho pra casa... Era uma umas duas horas de culto... tudo em alemão e todo mundo tinha que ficar quietinho, às vezes, se uma criança chorava, as crianças mais mocinhas foram aprendendo e pegavam as crianças que eram pequeninhas pra todo mundo ficar quietinho porque os pais queriam ficar no culto sem perder nenhuma parte. A igreja era um ponto de manutenção da língua ali. $O$ alemão era o mesmo da gente; às vezes o pastor falava um pouco diferente, mas a gente entendia... mas era diferente... A mãe tinha uma bíblia bem velhinha, mas era tudo em alemão... e ela ainda tem; ela lia a bíblia pra gente e explicava as histórias; mesmo falando dialeto a mãe conseguia ler a bíblia; só a mãe... eu não. Ela sentava com a gente... a mãe era uma pessoa muito calma... muito amiga... A mãe dela sabia ler... era minha vó que ensinava ela. Ela sabia ler e escrever, mas não sei se era o alto alemão; sei que pelo menos a bíblia ela conseguia ler. A minha mãe pegou mais porque a mãe dela ensinava; os pais e os avós que sabiam passavam pros filhos; só que a minha mãe não passou muito... talvez porque teve muitos filhos. A gente era em oito irmãos e tinha que ter muito tempo para querer ensinar todo mundo e aí não dava...

Ele não vai comigo visitar minha família; no começo até que ele ia, mas agora ele não vai porque ele se sente perdido no meio que todo mundo que fala em alemão e acha que a gente fica falando mal dele... ele se sente mal e se sente muito perdido, às vezes, ele vai junto, mas agora já tem gente que já fala em português... mas a gente fala muito em alemão e não gosta de ir... eu fui esses dias, faz uns quinze dias... eu fui no sábado e voltei no domingo... fiquei um final de semana lá ele ficou aqui na cidade e ele não gosta. Eu entendo o lado dele e me sinto até mal quando ele vai junto porque eu estou conversando eu quero saber da história da família... o que aconteceu... o que está acontecendo... tudo em alemão. Aí eu vejo ele perdido lá sozinho... e tu fica perdido porque tenho que dar um pouquinho de atenção. Se eu for sozinha, me sinto mais aliviada porque não preciso ficar pensando, posso falar com toda minha família... geralmente, todo mundo está e tu não consegue falar com todo mundo... quando ele não vai, eu não fico preocupada com ele porque ele precisa de atenção também... pra ele é difícil, é meio complicado Ele não fala nada de alemão. Mas ele não implica comigo por conta da língua, mas, às vezes, ele brinca, "aqueles alemão lá... não gosto de ir pra lá, aqueles alemão lá, fica falando em alemão e eu não entendo nada, você só fica falando... não tem nada a ver comigo." Eu entendo o lado dele completamente, não tem nada a ver com ele, mas a gente tem que fazer parte de família... toda a vida, a gente faz... Geralmente, gosto de visitar a família umas duas a três vezes ao ano e gosto de ficar de um dia pro outro. E o Valdir não vai, mas até é bom. (Risos)

$\mathrm{Na}$ família dele, no começo, a minha sogra não me aceitou muito bem também, não. Não sei porque, eu acho que ela não gosta de pessoas claras, alemãs. Ela não gosta, não é muito chegada... ela é contra a raça de alemães também. Mas, hoje em dia, a gente se dá bem, a gente se implica um pouco ainda, mas como se diz: "quem manda teu filho escolher a nora", né? No final todo mundo acaba se aceitando. 


\subsection{Análise das entrevistas}

\subsubsection{Zilma Seidler, 5 de janeiro de 2007}

Em primeiro lugar, passamos à questão do impacto da guerra sobre a língua, em virtude da recorrência do tema nas fontes pesquisadas. Em nossa opinião, a posição de que a língua imigrante teria sido prejudicada pela repressão durante a guerra deriva de uma generalização sobre a natureza da língua e não encontra respaldo na realidade lingüística das comunidades rurais, onde tais línguas permanecem existindo, parecendo ter sofrido, de acordo com nossos dados, maior erosão somente após a introdução da televisão, na região, na década de 1970, quando, de certa forma, o "urbano" invade o "rural". Como nos fala Zilma, as crianças que crescem na frente da televisão aprendem de forma diferente. Curiosamente, em nossas fontes, o impacto da televisão só aparece no depoimento de nossa entrevistada e parece amplamente ignorado com relação ao impacto sobre a manutenção das línguas imigrantes.

(...) mas hoje em dia já tem casas com luz tudo com banheiro tudo as escolas é tudo diferente com banheiro com tudo as professoras é outro nem não tem mais esse da minha época já foi mudando tudo até as criança tão vendo televisão tão vendo tudo já aprende pessoal da minha época era uma coisa hoje em dia da minha época não existe mais...

J - é você tocou uma questão muito interessante: a televisão...

J - então hoje, ah... quando você aprendeu alemão da sua família em casa você não tinha televisão?

$\mathrm{Z}$ - não tinha...

Seria ainda interessante notar que a guerra é o momento maior da expressão do não reconhecimento de diferenças; na guerra todos os dialetos são iguais; só há alemães e italianos; a guerra, portanto, tem impacto na construção de uma identidade coletiva que unificou o que não era originalmente único.

Se existe uma mudança lingüística que coincide com o pós-guerra, sobretudo nas áreas urbanas, ela parece ocorrer porque uma geração já bilíngüe parece ter escolhido não ensinar a língua de herança à próxima geração. Não podemos ignorar a guerra como fator contribuinte para essa escolha. Entretanto, responsabilizar exclusivamente a guerra por esta mudança lingüística é ignorar a complexidade das imposições sociais, a força das inovações tecnológicas do pós-guerra e a realidade das escolhas humanas, ainda que tal movimentação possa ter sido desencadeada como medida preventiva para que seus descendentes não sofressem de forma semelhante no futuro. 
Em termos mais práticos, é preciso que se compreenda o mundo do pós-guerra como um mundo de progresso muito rápido, onde as tecnologias de comunicação se aliaram a políticas de desenvolvimento e integração nacional que poderiam ser favoráveis a um language shift, decorrente simplesmente do processo de racionalização do Estado, em um contexto histórico que não reconhece a diferença.

No plano social, a integração e desenvolvimento do país acabam tendo desdobramentos muitas vezes inesperados na movimentação de comunidades na direção da saída de seus membros para outras regiões e na direção de uma maior abertura para casamentos com pessoas "de fora". De acordo com nossos dados, o casamento "fora da comunidade" parece ser um fator extremamente crucial de interferência no processo de transferência da língua para a próxima geração, e é um fato sobre o qual os próprios entrevistados demonstram consciência.

$\mathrm{Z}$ - da própria região lá perto. Não tem ninguém, pra dizer que ninguém casou única que eu me lembro: eu

(...)

$\mathrm{Z}$ - não, naquela região tudo lá no caso ninguém casou com... com... no caso como é que se diz com brasileiro eles dizem, a única pessoa lá da colônia mesmo fui só eu no caso por isso que fui muito discriminada lá naquela colônia lá, nos anos quando minha filha nasceu tudo eu não ia lá não ia lugar nenhum porque todo mundo me olhava e falava de mim tudo " foi essa aí que sujou a família, sujou nossa..." no caso eles usam essa palavra né aí tu ia lá tu se sentia tão mal todo mundo te olhava tudo daquela maneira discriminava assim "sujou a família, sujou nossa nossa região aqui em volta". Então, mas hoje em dia já vejo tudo diferente não é mais como na minha época

$\mathrm{Z}$ - faz 20 e poucos anos atrás isso era bem rígido hoje em dia já mais mesmo assim continua casando alemão com alemão

$\mathrm{J}$ - mesmo hoje em dia?

$\mathrm{Z}$ - mesmo hoje em dia, meus irmão todos casaram tudo com alemão com alemã, não tem mistura nenhuma, tem até uma irmã minha casou com segundo primo porque não tem é muito pequeno no final acaba se apaixonando um por outro acaba casando até meio parente.

$\mathrm{J}$ - e os filhos deles falam alemão

$\mathrm{Z}$ - falam tudo em alemão... tudo

Dada a complexidade das variáveis, a resposta mais correta será sempre a de que não há resposta correta sobre quais fatores detiveram maior poder sobre a mudança lingüística dessas comunidades, e podemos concluir que provavelmente todos esses fatores tiveram, em maior ou menor grau e em diferentes combinações, impacto sobre o desenrolar da evolução lingüística desses grupos. Mas não podemos, em momento algum, deixar de perceber que esses são apenas os fatores externos que, em última análise, serão determinantes sobre a escolha do indivíduo, seja essa escolha a de manter ou a de abandonar algo que lhe pertence. 
Sobre o dialeto, Zilma tem consciência de que fala um alemão diferente do que é falado na Alemanha, mas não sabe muito sobre ele ou mesmo sobre como a família veio parar no Brasil.

Z-É, município Angelina

$\mathrm{J}-\mathrm{E}$ você foi então... sua língua materna é... alemão.

$\mathrm{Z}$ - alemão

J - O alemão que você chama de alemão é um alemão culto, é um dialeto de alemão, é... que tipo de... que alemão você fala, porque existem vários dialetos de alemão na região.

Z - Sim mas o meu no caso é a dialeto.

$\mathrm{J}$ - Este dialeto você sabe a origem dele na, na na Alemanha, você tem alguma informação sobre isso?

$\mathrm{Z}$ - Eu na verdade nem sei como surgiu, no sei, no sei, como que nós viemo parar aqui.

Para quem não tem familiaridade com as áreas rurais do Brasil, a questão do acesso e da integração com centros próximos pode não chamar a atenção, mas o relato de Zilma deixa clara a questão do isolamento dessas comunidades. Tal isolamento impôs a esses indivíduos uma vida dura e freqüentemente perigosa por conta da falta de recursos médicos e de emergência.

$\mathrm{J}$ - Você chegou a trabalhar na na roça?

$\mathrm{Z}$ - Cheguei... na roça. Aí depois com os anos foi indo, foi indo, acho que tinha uns 10, 12 anos aí já começou vim a estrada, já começou a passar carro.

(..)

$\mathrm{Z}$ - Então naquela época lá quando eu nasci não tinha luz, não tinha nada, era muito pobre a colônia que a gente morava, meu pai que plantava e colhia e criava os bichos tudo aquelas coisa pa gente ir se virando né de manhã comprava açúcar as coisa até que tinha venda tudo que gente podia comprar que não tinha como a gente fazer aí também tinha gente que plantava cana e fazia açúcar tudo.

Zilma ainda relata que mesmo os contatos com as outras comunidades, freqüentemente oriundos da necessidade de adquirir suprimentos, não representavam contato com um mundo "não alemão" já que as outras comunidades também eram constituídas por imigrantes.

$\mathrm{Z}$ - Tinha, tinha, mas aí nos tinha cavalo, tinha boi, as carroça tudo que levava daí até chegar nas venda pa poder vender

J - E essas, essas vendas, esse comércio pelo que você lembra, esse comércio com as comunidades... adjacentes essas comunidades eram também comunidades alemãs ou não?

Z - Também é, não, já era mais fora no caso, mas era alemã também, só que eles já tinha as vendinha como pa pra tentar ajudar as pessoas ter pouquinho de dinheiro pa tentar comprar as coisa que não dava pra plantar e colher no caso pra não faltar

(..)

Z - Era mais ou menos umas duas horas de cavalo ou de boi até chegar lá tentar fazer as compra era longinho daí 
J - Aí você, então você só usava alemão

Z - Só, só

$\mathrm{J}$ - Você nunca aprendeu ...

Z - Não, não

É dessa forma que o primeiro contato de Zilma Seidler com o português se dará somente aos sete anos de idade quando vai para a escola. Na escola, as experiências não eram sempre positivas e as punições, castigos e piadas são um tema recorrente no depoimento de Zilma.

Z - Nenhum, até os sete anos era só alemão, alemão, depois dos sete anos a gente foi pra escola, aí

(...)

J - Como é que foi? Você lembra do seu primeiro dia na escola ?

$\mathrm{Z}$ - sim, tinha muito medo de ir pa escola. Mas a gente tinha que ir né, o pai brigava, pra gente ir "vocês vão vocês tem que aprender ler escrever e aprender" nos fomo mas a gente tinha muito medo de ir pa escola era uma coisa assim, a gente tinha que ir a pé, era uma meia hora ir a pé pa chegar na escola, a gente ia descalço, tudo, de chinelinho no caso, né? Aí a gente chegava lá. A professora era muito braba, ela às vezes quando a gente não sabia as coisa direito ela botava a gente de castigo alguém ficava de joelho quando não fazia as coisa direito ela era muito braba. A gente

(...)

$\mathrm{Z}$ - sim, ela chegou as vezes a torcer a orelha da gente chegava até a machucar a gente

Z - Muito, muito. Mas o medo atrabalhava muito do aprender também, porque a professora era muito rígida, muito braba, ela tinha até uma varinha na na sala de aula, se ela chegava lá vissse que nossa letra não tava correta tava meio torto ela batia assim no dedo da gente. "Pode apagar tudo, pode fazer tudo". As vezes a gente não entendia que ela falava, e ela sabia falar as duas língua a professora também dai ela falava em alemão pra gente entender que ela tava falando no caso ela tinha que saber falar as duas língua né por que a gente não sabia né

É difícil saber, por vezes, se Zilma fala de sua própria experiência ou de uma experiência coletiva; a expressão "a gente" parece freqüentemente usada como uma forma atenuada de "eu" - algo que não foi percebido durante as entrevistas e só veio à tona quando das transcrições. Coletivas ou não, essas são as experiências e as memórias de Zilma Seidler que relevam um contato difícil com o mundo fora da colônia.

Zilma também descreve como ocorria a comunicação na escola e revela que a realidade do bilingualismo na escola já havia imposto algum nível de solução para o problema de comunicação e que a professora da escola que freqüentava era bilíngüe em alemão e português.

J - O, o alemão que, bom, e aí vocês vão, vocês vão pra escola, e vocês, então vocês são educados em alemão e português

$\mathrm{Z}-$ isso

$\mathrm{J}$ - ao mesmo tempo. 
Z - é, no caso, se tu não entende a professora fala em alemão e começa de novo. Isso aí é assim...

$\mathrm{J}$ - Mas a aula era em português

$\mathrm{Z}$ - em português, é . Aí através de ir pra aula a gente vai aprendendo as duas línguas no caso.

(...)

J - Mas ainda assim, ela é da... ela é parte da comunidade?

Z - É... ela era parte, mas só que ela não era alemã mesmo, ela já era brasileira no caso.

(...)

Z- Só que ela sabia falar em alemão, que precisava, porque como é que ela ia ensinar os aluno sem saber se eles não tavam entendendo nada. No ia se perder...

Zilma ainda revela que as tentativas frustradas em lidar com o alemão diferente da professora também resultavam em castigos.

J - O alemão, o alemão que ela falava era dialeto, ou era alemão culto...Você tem registro disso?

Z - Não...o dela, não o dela era diferente

(...)

$\mathrm{Z}$ - Porque a gente entendia só que o dela era diferente o nosso.

(...)

J - E como é que foi, como é que era o impacto disso. Você na sua família você fala um alemão, na escola você vai pra pra escola e o alemão da professora é diferente. Como é que, como é que você lidava com essa diferença de entre o alemão de casa e o alemão da escola?

$\mathrm{Z}$ - A gente tentava adivinhar no caso, acertar. Aí se tu não acertava tu ficava tu ficava quieto daí ficava aquilo mesmo mas não (inaudível)

J - Ficava quietinho pra não...

Z - É Pra não ficar de castigo uma coisa assim, que ela era muito braba, muito rígida, tu não entendia, ela qualquer coisa ela botava a gente de castigo, em cima no sal, no caso, de joelho, ela era muito braba...quantas vezes...aí tu tinha que ficar de joelho mesmo, não podia nem se abaixar, ela ficava do ladinho, ela era muito....

(...)

$\mathrm{Z}$ - é, era mais ou menos uns vinte alunos. Mas ela pegava $1^{\mathrm{a}}$. Série, $2^{\mathrm{a}}$. Série, e a $4^{\mathrm{a}}$. Série junto na mesma sala

Algo que chamou a atenção no depoimento de Zilma foi a correlação entre o abandono do alemão e o número de gerações e nos confunde ao informar que a mãe sabe ler e escrever em alemão.

J - Você não aprendeu a escrever em alemão?

Z - Não, não tinha, não tinha professor que ensinasse a gente, que ensinasse escrever em alemão. Porque ela era brasileira, no caso, só que aí não deu para nos ensinar. A minha mãe

(...)

$\mathrm{Z}$ - Ainda sabe, sabia ler e escrever em alemão mas eu não tive esta...

J - Você só fala...

Z - Só falo. Não aprendi. Porque na época da minha mãe, a minha mãe sabe ler e escrever tudo em alemão...eu já não, uma pena porque hoje em dia eu sei quanto que é importante a pessoa sabe ler e escrever em alemão só que eu não aprendi esta parte porque minha geração já é muita geração, né? 
Zilma ainda fala que, apesar de perceber que seu alemão era diferente do usado pela professora, tinha medo de falar sobre isso com os pais.

$\mathrm{Z}$ - Na verdade, os pais da gente era muito rígido, muito brabo, e a gente não tinha coragem de perguntar pros pais a gente ficava naquilo guardado pra gente mesmo, por que que era diferente?

J - Mas você tinha essa, essa questão...

$\mathrm{Z}$ - Eu tinha, eh, tinha vontade, mas os pais da gente era muito rígido, então o respeito e o medo era muito grande, a gente não perguntava muitas coisas pros pais a gente tinha curiosidade de perguntar tudo mas o medo o respeito naquela época meu pai era muito autori... muito brabo não podia fazer nada errado tudo certinho então tinha coisas que a gente tinha vontade de perguntar e tudo nunca falaram sobre nada sobre...

Zilma ainda nos fala de um mundo onde a discriminação parece vir de todo lado, até mesmo das crianças de fora da comunidade, e onde sua língua materna tinha de ficar escondida.

Z - Tinha. Enquanto eu tava minha $2^{a}$. Série lá chegou um casal mais de fora vieron morar mais próxima do colégio onde eu estudava eles tinha dois minininho uma menina só que os menino era tão moleque tão rebelde eles sabia que a gente tinha medo sei lá que que era eles discriminava a gente na sala de aula fora tudo eles falava avacanhava com a gente roubava mochila da gente "seus alemão" xingava a gente e a gente tinha medo deles, engraçado, tinha medo deles

(...)

Z- Sim, eles chegava até roubar minha mochilinha, quantas veis eu chorava.... Eles só rindo daí o outro que as veis não sei da onde que eles surgiram aqueles menininho eles era muito moleque eu acho que eles via que a gente era criado muito aquele tenso aquele medo tudo certinho mas eles era muito... aí eles tinha um negócio um tipo uma armazinha revolvezinho, eles começava "eu vou matar vocês" e nois sai gritando, gritando, tinha tanto medo deles

(...)

$\mathrm{J}$ - mas eu eu acredito que ainda assim vocês falassem alemão

$\mathrm{Z}$ - é escondidinho,

J - no recreio....

$\mathrm{Z}$ - ah, no recreio sim, no recreio a gente brincava falava tudo em alemão na hora do recreio

Sobre o status do dialeto e da variante da professora, Zilma nos fala sobre a existência de um sentimento de inferioridade.

$\mathbf{J}$ - Os seus pais nunca fizeram comentário, nunca conversaram sobre a questão do alemão da escola ser diferente do alemão que você falava na sua casa?

Z - Não

$\mathrm{J}$ - Pra eles era a mesma coisa?

$\mathrm{Z}$ - talvez que não. Eles as vezes comentava que era diferente eles dizia que o deles era melhor que o nosso no caso né

$\mathrm{J}-\mathrm{o}$ deles...

$\mathrm{Z}$ - o da professora no caso era mais o alemão mais forte

J - melhor?

Z-é

J - nunca o contrário?

Z - não 
$\mathrm{J}$ - ta, é isso, eu acho isso muito interessante, por que melhor? É a minha, Essa é a minha pergunta: por que melhor?

$\mathrm{Z}$ - Por que eles achava que o alemão que eles, como é que ele sempre dizia " eu acho que o alemão deles é mais alto" meu pai dizia

(...)

$\mathrm{Z}$ - na cabeça dele a gente foi aprendendo essa palavrinha " o alemão deles é mais alto, o nosso é mais pequeno" ele falava, naquela época, que era dialeto no caso, mas na cabeça dele a gente já pensava diferente você ... não

$\mathrm{J}$ - o dialeto que você aprendeu tem um nome, você sabe se ele tem nome,

$\mathrm{Z}$ - não

J - Não... vocês vocês só chamam de dialeto

$\mathrm{Z}$ - é, só, dialeto.

Falando sobre o aprendizado de alemão do filho, Zilma faz planos de deixá-lo aprender com a família e reconhece o convívio como essencial para o aprendizado. Zilma acha as iniciativas de ensinar alemão na escola válidas, mas não acredita que o tempo seja suficiente para que as crianças aprendam se não estiverem dentro de um contexto que favoreça esse aprendizado. Zilma ainda fala da amiga que depois de dois anos estudando alemão ainda não aprendeu "quase nada".

Z - deixar um mês lá, dois três meses lá no meio pra aprender falar conviver só com alemão mas eu não fiz isso acho que seria mais fácil porque daí convivia junto tudo e aprendia porque tu falar sozinho sem todo mundo junto é difícil tu... ele pegar falar mesmo como é que eu aprendi porque é muita coisa tu conversando o alemão não é uma língua muito fácil de falar

(...)

$\mathrm{J}$ - eu te pergunto então à luz disso que você acabou de falar existem umas iniciativas hoje no país que querem colocar educação bilíngüe pra... pra determinadas comunidades como a sua, no caso semelhantes, e que querem é ensinar alemão no caso pra pra uma comunidade germânica, assinar ...ensinar um alemão culto pra garotada que está na escola é, como é que você vê isso, assim, que... que opinião você tem sobre esse tipo de iniciativa?

$\mathrm{Z}$ - eu acho muito interessante, eu acho muito bom que continuasse a mesma...

J - Mas você acha que, você acabou de dizer uma coisa interessante, é... é difícil você aprender a língua quando você está fora da do contexto.

$\mathrm{Z}-\operatorname{sim}$

$\mathrm{J}$ - é, você acha que seria suficiente pra estas pessoas adquirirem a língua?

(...)

$\mathrm{Z}$ - eu acho que não porque aprende muito pouco é muito pouco tempo porque é muito pra tu aprender mais cê tem que conviver o que tu aprende no caso passa pra tu te virar mas falar em alemão mesmo vai ser muito complicado.

(...)

Z - porque também tudo isso aí para escola eu não mas a gente sabe conversar normalmente tudo conversando falando tudo porque tem muitas amigas que ela até ta fazendo o alemão de Balneária ela é daqui, ela ta dois anos fazendo curso ela não aprendeu falar em alemão ainda por que é difícil

$\mathrm{J}$ - e ela ta fazendo curso de alemão?

$\mathrm{Z}-\mathrm{ta}$

(...)

Z - aí, amanhã é aniversário a tá amanhã ela vai vir, quero ver se ela vem, então ela ta dois ano na aula de alemão mas não aprendeu quase nada. 
Sobre o português aprendido na escola, Zilma fala de como foi levado para dentro de sua casa por ela e pelos irmãos.

Z - não, isso aí foi interessante eles acharam legal a partir disto que a gente aprendia na escola a gente foi passando pros pais aí a gente foi ensinando tudo que a gente aprendia já passava pra eles, aí eles começaram com o que a gente sabia falar a gente falava com eles ensinando eles também começava a aprender também só que a minha vó, já morreu tudo mas nunca falou uma palavra em em português mas os meus pais já aprenderam falar em português através da gente ia pa escola e meus irmãos tudo continuaram indo pra casa tudo e conseguiram aprender pouco a língua pra poder se virar se saísse fora daqui conseguiram se virar daí

Perguntada sobre como incentivar o alemão que recebeu de seus pais, Zilma fala sobre um sentimento de vergonha e de sua percepção de que "ninguém quer levar mais adiante."

$\mathrm{J}$ - deixa eu te perguntar uma coisa um pouco mais vaga mas ao mesmo tempo uma pergunta que eu acho uma pergunta que eu acho interessante. O que que você acharia, na sua opinião, assim, tendo, pela experiência que voclê tem de vida, pelas coisas que você viu na sua casa pelas coisas que você ta vendo com relação a educação do seu filho, o que que você acharia uma iniciativa, qual, como é como é que se poderia de fato incentivar o que o que é que se poderia fazer pra incentivar o uso do alemão que você recebeu em casa da do dos seus pais,? Tem alguma coisa, você consegue enxergar alguma coisa que possa ser feita pra pra incentivar isso?

$\mathrm{Z}$ - pra continuar?

(...)

Z - eu acho, como é que se diz, os alemão são tão, como é que se diz eles se sente tão envergonhado eu acho que eles são alemã, ninguém quer levar mais a diante.

(...)

$Z$ - todo mundo ta se sentindo mas hoje em dia eu vejo é muito importante mas quem mora lá não quer não queria ser alemã.

\subsubsection{Mateus Fuck e Thamara Dorigon - 26 de Julho de 2007}

A seguir, procedemos à análise das entrevistas de Mateus, Tâmara e Janete. Essas entrevistas contaram com a presença e o auxílio de Andréia Afonso, que em muito facilitou até mesmo o acesso a esses jovens. As entrevistas foram colhidas na casa da Avó de Mateus, no centro de Angelina, e o clima foi bastante descontraído. O tom foi quase sempre de brincadeira e os jovens pareceram a vontade para falar essencialmente sobre as nossas questões lingüísticas.

A maior dificuldade para os entrevistadores foi, sem dúvida, a neutralidade. Muitas vezes essa neutralidade foi comprometida, ainda que de forma não deliberada, em prol do clima de brincadeira e descontração necessário para entrevistar adolescentes. O resultado, freqüentemente entrecortado por nossas próprias falas, é muito próximo ao de uma conversa natural, onde interlocutores se interrompem e completam pensamentos na construção de um diálogo. Tecnicamente, as entrevistas estão longe da neutralidade ideal e muitas das 
interrupções e comentários desnecessários só ficaram visíveis quando da transcrição do material. O resultado, contudo, contém informações que consideramos valiosas, sobre como esses jovens se relacionam com questões lingüísticas e identitárias. Para mantermos a objetividade com relação às questões, a transcrição é aqui parcial e restrita aos segmentos de nosso interesse. Mateus e Thamara são primos e foram entrevistados simultaneamente. Mais tarde Janete, falante de dialeto e residente da área rural que trabalha para a família Fuck viria juntar-se ao grupo. Mateus cursava a $7^{\mathrm{a}}$. série do ensino fundamental e Thamara a $3^{\mathrm{a}}$. série do ensino médio, quando das entrevistas, ambos alunos da escola pública do município.

Sobre a questão da identidade nacional, os jovens se declaram brasileiros sem hesitar e, em nenhum momento, fazem comentários ou deixam transparecer um vínculo identitário com a nacionalidade alemã - ao contrário de Zilma Seidler para quem parece existir uma dupla identificação. Essa consideração remete à questão dos parâmetros para o estabelecimento do que constitui uma língua imigrante, lembrando que para Ghambir (2001, p.212) é necessário um vínculo cultural que aqui pareceu bem diluído. Tal consideração nos faz refletir sobre a importância da faixa etária das pessoas envolvidas com o desenvolvimento de políticas lingüísticas. Zilma nasceu em 1963, no entanto seu vínculo identitário com a nacionalidade alemã parece bastante diferente e muito maior do que o vínculo dos jovens entrevistados. A conclusão sendo que, talvez, uma geração não sirva como parâmetro para os vínculos identitários de outra, reforçando a noção de um processo gradual de assimilação, como descrito por Valdés (2001, p.42) e do qual até os jovens entrevistados parecem ter consciência como vemos neste trecho.

Jordan- Hum, então é bem grande, né? E você, qual é a sua nacionalidade?

Mateus - Brasileiro.

$\mathrm{J}-\mathrm{E}$ você?

Thamara - Brasileira também.

$\mathrm{J}-\mathrm{Tem}$ certeza?

[risos]

T - Tenho.

J - Olha só... Sua família é de que origem?

$\mathrm{T}$ - Minha mãe é de origem alemã e meu pai de origem italiana.

J - Sua família é de origem alemã e italiana?

$\mathrm{T}-$ Isso.

$\mathrm{J}-\mathrm{E}$ a sua família?

M - A minha é de origem alemã.

$\mathrm{J}-\mathrm{Hum}$.

$\mathrm{M}$ - O pai e a mãe.

J - Certo. Se perguntar para a sua mãe qual é a nacionalidade dela, o que ela responde?

M - Vai dizer, eu acho, brasileira.

J - Hum... E se perguntar para a sua mãe... a sua mãe é que é do lado da família alemão, né?

$\mathrm{T}$ - Alemão. 

responde?

$\mathrm{J}$ - Se perguntar para a sua mãe qual é a nacionalidade dela, o que ela

$\mathrm{T}$ - Acho que, também, brasileira.

$\mathrm{J}$ - E se perguntar pros seus avós, o que eles respondem?

T - Ah, daí não sei.

Com relação a heterogeneidade das comunidades, também se constata a existência de outros grupos minoritários na região que dão conta do processo de fluidez étnica que modificou a constituição dessas populações ao longo de mais de um século e que agora representam um fator que agrega complexidade ao desenvolvimento de políticas que se baseiem na constituição étnica de dada localidade. É curioso notar todavia que a comunidade, na voz desses jovens, percebe-se germânica, descartando a existência de outras etnias. uma exceção?

J - Tem muita gente de origem italiana aqui também - ou a sua família é

T - Poucos, né?

$\mathrm{M}-\mathrm{E}$.

T - Têm poucos... não é muito não.

$\mathrm{J}$ - Poucos. Então esses casos são casos raros... casos isolados.

M - Porque a gente já foi, né, colonizado por imigrantes alemães.

Sobre o convívio com o dialeto, parece existir, de acordo com a percepção desses entrevistados, uma atitude positiva de convívio, apesar de ocasionais brincadeiras. $\mathrm{Na}$ transcrição abaixo os jovens deixam clara a consciência sobre a existência de um modo de falar diferente, referindo-se ao português dos colegas que falam o dialeto. Quando perguntados, todavia, sobre a natureza dessa diferença, apontaram para o sotaque carregado e ao que Thamara descreveu como exageros visíveis até nos cadernos dos colegas que falam alemão. Thamara não é clara, contudo, sobre esses exageros.

J - Mas então vocês vão à escola com um monte de gente que vem do interior - que vem dessas famílias alemãs. Como é que é estudar com esse pessoal?

T - Pra mim já é normal.

M - Pra mim também, porque a gente até acaba conhecendo... né... um pouco dessa língua.

J - Por que vocês também não são muito diferentes... vocês são meio alemães, né?

M - É, só que a gente não fala assim, né? falam.

J - Pois é, então tem essa diferença entre vocês que não falam e eles que

$\mathrm{M}-\mathbf{E}$.

J - Como é que é essa diferença, que tipo de diferença é?

$\mathrm{T}$ - No modo deles de falar.

J - Como assim? Fala... explica...

(...)

$\mathrm{J}$ - Mas, fora o sotaque, tem alguma outra coisa no português deles - você percebe que o português, em si, é diferente? Por que eu percebi, por exemplo, que você fala um português perfeitinho, todo bonitinho, né... E você... (Mateus) também. Como é o português deles? Vocês notam diferença entre o português que vocês falam e o... 
M - Ahã.

$\mathrm{J}-\mathrm{Umm}$.

$\mathrm{M}-\mathrm{E}$ diferente.

$\mathrm{J}-$ É diferente como?

M - Tipo o "r", assim, né?

$\mathbf{J}$ - Mas isso é pronúncia. Isso ainda está no campo do sotaque. Você nota, por exemplo, que, às vezes, eles usam palavras diferentes, vocês percebem algum vocabulário diferente... vocês percebem... a gramática é diferente?... tem alguma diferença na estrutura? Por exemplo, eles conjugam os verbos da mesma forma que vocês, vocês conseguem notar alguma coisa?

$\mathrm{M}$ - É igual. O vocabulário é o mesmo.

$\mathrm{J}-\mathrm{O}$ português deles então é como o de vocês.

M-É...é.

$\mathrm{J}-$ Exceto pelo sotaque.

$\mathrm{M}-\dot{\mathrm{E}}$.

$\mathrm{J}$ - Você concorda com isso?

$\mathrm{T}-\mathrm{E}$, por que, até na maneira de escrever, se eles escrevem meio diferente, assim mais pelo "R", entende, eles puxam mais assim.

J - E aí acabam escrevendo diferente por conta disso?

$\mathrm{T}-$ É. É, algumas coisas assim,

J - Tipo três $r$ 's numa palavra?

[risos]

T - Não... não três $r$ 's, mas eles exageram às vezes - dá até pra ver nos cadernos dos meus colegas que falam alemão.

Ainda no trecho transcrito acima, fica visível a questão das necessidades particulares desses alunos. Ainda que estejamos nos referindo aqui à língua portuguesa. Nossos entrevistados apontam para o que percebem como uma diferença que pode representar uma espécie de desvantagem no universo dos falantes de português. No caso da inserção da língua imigrante nas escolas, os falantes de português passam a estar em desvantagem. Um empate de desvantagens pode parecer justo, mas será a melhor maneira de abordar estas disparidades?

Ainda sobre as atitudes lingüísticas, fica claro que estas comunidades não estão isentas de sua cota de preconceitos mesmo entre as crianças e jovens. A questão importante aqui é sobre sua origem já que, como podemos ver no trecho abaixo, na fala de Thamara, "todo mundo" achou graça do jeito como Marlete falava - algo um tanto estranho se lembrarmos que Marlete provavelmente não era a única pessoa com sotaque diferente na sala de aula.

J - Hã. Mais cedo, quando a gente estava conversando, vocês disseram que tinha algumas coisas, infelizmente a gente não estava gravando, vocês falaram que tinha... que, às vezes, vocês achavam graça... que as pessoas achavam graça deles. Como é que é isso?

T - Isso. Tinha uma - o nome dela até era Marlete, daí a professora chegou e perguntou em que localidade ela morava, daí ela falou "Palheiros", só que ela falou mais puxando assim... e daí todo mundo caiu na gargalhada, e sempre riam assim dela, do jeito que ela falava.

$\mathbf{J}$ - A garotada na escola ria da maneira como ela falava... sendo que, na maioria dessas escolas, as pessoas também falam... pelo que você descreveu... também falam diferente, e falam como ela.

T - Ahã.

J - Então não estou entendendo mais nada. Estou confuso. Quem ri de quem, quando e por quê? 
[risos]

M - Não, mas agora não tem muita graça porque...

$\mathrm{J}$ - Perdeu a graça?

[risos]

M - Não, porque agora essas pessoas assim, passaram a conviver com essas pessoas que falam assim em alemão, daí não...

$\mathrm{J}$ - Acostumou?

$\mathrm{M}$ - É, não tem mais graça. No começo, tem gente que ri, mas depois não.

$\mathrm{J}$ - Depois acostuma. E vocês acham - você particularmente acha graça?

M - Não.

J - Acostuma, né?

Sobre as dificuldades do ensino de línguas na localidade, os jovens lembram que o professor do curso livre de inglês onde os dois primos estudavam tinha ido embora.

$\mathrm{J}$ - E vocês têm aula de alemão na escola?

M - Não, na escola não.

$\mathrm{J}-\mathrm{Nem}$ você.

T - Não. Comecei freqüentando um cursinho de inglês, mas o professor chegou a ir embora, mas era uma aula...

J - Ah é? O professor de vocês - não, é...então vocês dois estavam estudando inglês juntos.

$\mathrm{T}-\mathrm{E}$.

$\mathrm{J}$ - Isso, mas não na escola.

T - Não na escola. Na escola também tem. E numa escola de inglês.

J - Era uma escola de inglês, era um professor de inglês?

$\mathrm{T}$ - Era um curso.

Ainda sobre a questão da língua estrangeira na escola, o inglês, no caso, Thamara diz que não aprendeu nada e Mateus acrescenta que não aprendem a falar e define o ensino como fraco, apontando até as deficiências que percebe no professor que segundo ele não "mostra direito" como falar. As observações de Mateus, se corretas, parecem apontar para um ensino de língua estrangeira de caráter instrumental e remete a questionamentos sobre o tratamento e mesmo sobre a eficácia das línguas estrangeiras no cotidiano das salas de aula do ensino público.

$\mathrm{T}$ - Só que bem... a gente começa a aprender na $5^{\mathrm{a}}$. Série, e da $5^{\mathrm{a}}$. Série até agora [terceiro ano do ensino médio] eu falo que não aprendi nada.

$\mathrm{M}$ - Tem, mas é fraco.

$\mathrm{J}$ - Mas tem inglês. diariamente.

M - Mas só que a gente aprende mais a ler em inglês e não a falar assim,

$\mathrm{T}$ - Também porque o professor chega na sala e pede pra gente fazer as atividades, explica até tudo, mas ele não mostra assim direito a tradução ou como falar aquilo.

Sobre a importância relativa entre o inglês e o alemão, Mateus acredita que o inglês é mais necessário e acrescenta que tudo é em inglês por causa do computador. 
M-É.

$\mathrm{J}$ - O que você acha disso? Você tem aula de inglês - você vem de uma família alemã... você tem aula de inglês... não tem aula de alemão, o que você acha?

M - Por que assim o inglês hoje é o que a gente precisa mais, né? Agora com computadores é tudo em inglês, né, essas coisas.

(..)

M - A gente usa mais o inglês do que alemão.

Já Thamara, sobre o inglês, reconhece a importância para o mercado de trabalho e diz que mesmo o supermercado local daria preferência a alguém que falasse inglês.

J - Você está falando "até na profissão", que profissão você está pensando especificamente?

T - Por exemplo, no supermercado, aqui no caixa, uma pessoa que sabe falar inglês, eles exigem mais o inglês do que o próprio alemão.

Quando perguntamos a Mateus sobre a utilidade das línguas estrangeiras, o alemão dos avós não foi, inicialmente, sequer mencionado. Mas Mateus acaba dizendo que o "certo" seria aprender "todas as línguas" ao mesmo tempo em que deixou implícita a impossibilidade decorrente da realidade da alocação de recursos a serem investidos pelo aprendiz. É diante dessa realidade que Mateus afirma ser o inglês melhor; muito embora, ele seja o único jovem da cidade estudando alemão padrão com o pastor que dá aulas semanais. A situação da oferta exclusiva do alemão, nesse caso a única língua que ele pode estudar fora da escola em Angelina, dificulta o estabelecimento dos motivos pelos quais Mateus faz o curso.

J - Hum. Você acha - se você pensar a médio e longo prazo, quando você pensa no seu futuro profissional, o que você acha mais útil pra você, em termos de aprender uma língua estrangeira, o que você acha que seria mais útil - aprender inglês, aprender alemão, aprender italiano, o que você... ?

\section{M - Inglês. Inglês e espanhol.}

J - Apesar de você vir de uma família de origem alemã, onde os seus... A sua mãe fala alemão?

M - Não.

J - Só sua vó fala alemão?

M - Também não.

J - Também não. Já perdeu lá atrás.

E você acha que o inglês é melhor que o alemão, ou o alemão é melhor que o inglês, que o italiano é melhor do que os dois? O que é que você acha?

$\mathrm{T}-\mathrm{O}$ certo seria saber de todas as línguas, né, mas...

J - É impossível, né, não dá. também.

T - É, mas eu acho que, como é mais usado o inglês, eu acho que é melhor

M - Eu não acho que nenhuma é melhor que a outra, mas o inglês precisa mais, né?

$\mathrm{J}$ - Você acha mais útil?

M - Porque agora no computador tem programa é tudo em inglês, aí tu pega o dicionário né? Se tu não souber. 
Diante da opinião de Mateus de que o ideal seria aprender todas as línguas e sua constatação de que isso não seria possível, somos forçados a avaliar a questão dos recursos a serem alocados para o aprendizado. Até que ponto podem os recursos do aprendiz ser alocados para diferentes finalidades de aprendizado sem que haja comprometimento desse processo? Será o limite, caso exista, igual para todos?

Thamara, sobre as aulas de alemão, confessa desconhecimento e não se mostra muito interessada.

J - Bacana, muito bem. E você não está fazendo aula - você vai também?

T - Não, eu não vou.

J - Não tem vontade?

T- Eu nem sabia.

J - Mas agora que você sabe, não ficou com uma coceirinha para ir lá aprender alemão com seu primo?

T - Não sei, eu acho que não.

Sobre a dificuldade entre o inglês e o alemão, os jovens estão divididos. Mateus acha que o inglês é mais difícil e Thamara acha o contrário. Apesar disso, existe consenso entre ambos sobre a maior utilidade do inglês com relação ao alemão.

J - Olha só, você disse que estava aprendendo inglês na escola. Entre o inglês da escola e o alemão, qual você acha mais difícil?

$\mathrm{M}$ - Acho que é o inglês.

J - Você acha o inglês mais difícil de aprender do que o alemão?

$\mathrm{M}-$ Ahã.

$\mathrm{J}$ - Por quê?

M - Ah, não sei, as palavras são mais difíceis.

É muito importante notar que, tanto para Mateus quanto para Thamara, a população local não parece muito interessada no alemão. Mas ambos reconhecem que a introdução da língua na escola acabaria levando ao costume e ao aprendizado. Mateus, no entanto, declara ser o alemão uma língua desconhecida. Para ele e sua prima, o alemão representa a oferta de mais uma língua estrangeira.

J - Interessante. E você, o que você acha? Embora você não faça aula de alemão, você acha que o inglês é mais difícil do que o alemão ou o alemão é mais difícil que o inglês?

T- Ah, eu acho que o alemão é mais difícil que o inglês.

(...)

J- Deixa eu mudar, um pouquinho, de assunto. O que vocês acham se tivesse alemão na escola - vocês tem inglês na escola, e se tivesse alemão na escola?

T - Eu acho que isso é meio impossível de acontecer aqui.

$\mathrm{J}$ - Por quê? Porque os professores fogem?

[risos]

$M$ - Não...porque aqui as pessoas não tem muita vontade...

$\mathrm{T}$ - Não se interessam muito 
M - É, não tem muita vontade de aprender outras línguas. Só aprendem inglês - nem aprendem - porque o professor está lá, tem aula lá, porque tem que aprender. Porque senão nem aprendia nem fazia questão de aprender.

$\mathbf{J}$ - E se de repente tivesse - se alguém dissesse isso aqui é fantástico e começasse a ter alemão na escola. E aí, faz o quê agora? O que você iria achar disso?

T - Daí eu acho que os alunos passando a conviver com essas aulas eles iam se acostumar e iam aprender.

$\mathrm{J}$ - E você, você acha a mesma coisa? Que iam acabar se acostumando? interessante.

M - É uma língua diferente que a gente não conhece, acho que ia ser

\subsubsection{Janete Müller- 26 de julho de 2007}

A jovem Janete Müller tinha 19 anos, quando dessa entrevista. Janete é proveniente da área rural do município e fala o dialeto que é sua língua materna. Janete descreve a si e aos pais como brasileiros, mas deixa bem claro que os pais só sabem falar alemão.

J - Me disseram que você vem de uma família alemã, aí embrenhada aí pra dentro. É verdade isso?

$\mathrm{JM}-$ É verdade.

$\mathrm{J}$ - E você sabe alguma coisa sobre a origem da sua família?

JM - É a minha vó já falecida só falava em alemão. Ela cantava em alemão, lia a bíblia em alemão.

J - Tudo em alemão.

JM - Tudo em alemão, é. E o vô também.

$\mathrm{J}-\mathrm{E}$ os seus pais?

JM - Meus pais só sabem falar alemão.

$\mathrm{J}-\mathrm{E}$ você fala alemão também.

JM - Eu falo alemão e brasileiro.

$\mathrm{J}$ - Você ... Se eu perguntar sua nacionalidade, o que você responde?

$\mathrm{JM}-\mathrm{Ah}$, sou brasileira.

J - Se eu perguntar para os seu pai e pra sua mãe, o que eles respondem?

JM - Brasileiro também.

J - Ah, é? Ta bom. E, ah, como é que você aprendeu alemão?

JM - Como a gente lá em casa, a mãe só falava em alemão, onde não tinha ninguém pra ensinar o português, e mesmo quando a gente ia pra escola a professora ela falava em português mas ela entendia em alemão; daí se a gente não soubesse falar em português daí a gente podia falar em alemão, que ela sabia responder em português daí que nós aprendemos a falar o português e o alemão.

J - Então o alemão você aprendeu em casa.

$\mathrm{JM}-\hat{\mathrm{E}}$.

J - E aí você vai pra escola, e se for preciso você fala em alemão, a professora entende e te responde em português, é isso?

$\mathrm{JM}-\hat{\mathrm{E}}$.

É impossível não reconhecer aqui os ecos das falas de Zilma quando se refere a sua língua materna e é diante da convicção com que falam de sua língua materna que compreendemos a importância do dialeto para essas pessoas. 
Fica imediatamente claro para nós que o alemão tem significado diferente para Janete e para Mateus e Thamara. Janete também possui consciência de que seu alemão é diferente e que provavelmente não conseguisse se comunicar com um alemão da Alemanha.

J - E esse alemão que você fala em casa, é alemão... porque o Mateus ainda acabou de falar que o alemão daqui é um alemão diferente. Você tem noção, você percebe essa diferença, você concorda com isso, como é esse negócio do alemão?

JM - Acho que depende da pessoa também. Tem alguns que tem mais facilidade de falar e tem uns que tem mais dificuldade para falar. Daí depende da pessoa eu acho.

J - Mas, por exemplo, você fala alemão que você aprendeu na sua casa. Se chegasse um alemão da Alemanha aqui, você consegue conversar com ele?

JM - Acho que algumas coisas assim eu conseguiria, mas tudo, tudo assim eu acho que não porque é diferente lá, do que o alemão daqui.

$\mathrm{J}$ - Era isso que eu queria saber: é diferente então.

JM - É diferente.

Janete nunca estudou alemão na escola e, como os demais jovens de Angelina, ela só estuda inglês. Apesar de falar alemão, ela não sabe ler nem escrever a língua de seus pais.

$\mathrm{J}$ - O alemão é diferente. E você nunca estudou alemão na escola?

JM - Não.

J - Nunca teve aula de alemão na escola?

JM - Não.

J - Então todo o alemão que você sabe você aprendeu na sua casa. Você sabe escreverem alemão ou não?

JM - Não, eu não sei.

J - E você sabe ler?

JM - Não.

J - Também não, você só sabe falar.

JM - Só sei falar.

J - Como é o português na sua casa. Se você aprendeu o alemão em casa, você só fala alemão com os seus pais, eu imagino, ou só falavam alemão. Vocês usavam, ou usam o português em casa?

JM - Agora de vez em quando eles falam um pouquinho em português. O pai e a mãe, agora eles aprenderam. Porque no começo eles não sabiam falar em português, só em alemão. Mas daí quando eles começaram a sair, falando com as outras pessoas eles começaram a aprender e estão aprendendo a falar.

Para Janete, aprender alemão é mais fácil do que aprender inglês e ela acredita que outras pessoas partilham a mesma percepção.

J - Você teve inglês na escola?

JM- Na escola eu tive inglês.

$\mathrm{J}$ - O que você acha mais fácil de aprender, inglês ou alemão.,

JM - Acho que o alemão é mais fácil de aprender do que o inglês.

$\mathrm{J}$ - Por conta de você ter aprendido em casa, é por isso? Ou...

JM - É talvez seja por isso, mas tem gente que acha mesmo que o inglês é mais difícil que o alemão para aprender; também algumas palavras é muito parecido o inglês com o alemão.

J - Hum hum. Você é muito novinha. Você pretende fazer falculdade?

$\mathrm{JM}$ - Se der, eu faço uma faculdade, assim. 
Para Janete, faculdade não é uma certeza e trabalho "não se escolhe".

$\mathrm{J}$ - E quando você pensa no futuro, um dia, o que você pensa em fazer, quais são as coisas com as quais você gostaria de trabalhar?

JM - Pra mim, assim, nunca escolhi trabalho. Pra mim, qualquer coisa sempre tava bom, porque a mãe sempre falava: trabalho a gente não escolhe, trabalho a gente consegue com esforço, né?

J - Ahã.

JM - Não sei o que eu vou fazer, assim, vou ter uma idéia do que eu vou querer ser, o que eu vou fazer futuramente.

Sobre escolher uma língua estrangeira, Janete preferiria estudar o inglês e o alemão e escolheria alemão se tivesse de escolher entre as duas. Assim como Zilma, Janete tem alta prioridade para sua língua materna e uma relação com o dialeto que é diferente da relação que o Mateus e a Thamara têm com a língua de seus ancestrais. Fica aqui evidente que, se a escola passasse a incluir o alemão para esses jovens, suas necessidades seriam drasticamente distintas. Ao longo deste trabalho, os termos "dialeto" e "variante padrão" foram utilizados inúmeras vezes. Foi analisando as falas de Janete, no entanto, que confirmei algo que já havia encontrado nas falas de Zilma. Para ambas, "alemão" e "dialeto" não são sinônimos porque elas não usam o termo "dialeto" a menos que a distinção se faça necessária. Elas se reconhecem como alemãs, da mesma forma que reconhecem a nacionalidade brasileira. Se elas são, em algum nível, alemãs, falar alemão é uma conseqüência natural. Para ambas existe um alemão diferente, mas que é alemão também. Talvez exista o "alemão" da Zilma e o "alemão" da Janete que nem sequer sabemos ser o mesmo, a menos que pudéssemos tê-las juntas para conversar.

$\mathrm{J}$ - E você, se um dia na vida você precisar de uma língua estrangeira, você acha que o alemão pode ser útil pra você, que o inglês pode ser útil, o que você acha se um dia você precisar de uma língua estrangeira, o que seria mais útil pra você?

$\mathrm{JM}-\mathrm{Eu}$ acho que o inglês seria mais útil, porque muita gente fala inglês e não fala o alemão. Tem mais gente que fala inglês do que alemão.

J - Mas,no entanto, você disse também mais cedo que você gostaria de ter aprendido inglês [sic alemão] na escola.

$\mathrm{JM}$ - É, eu gostaria de aprender o inglês.

$\mathrm{J}$ - Será que eu posso entender disso que você gostaria de ter aprendido os dois na escola?

JM - É, os dois assim, se for pra mim estudar mais uma língua, eu preferiria estudar o inglês.

$\mathrm{J}-\mathrm{E}$ se você tivesse que escolher entre as duas, qual você escolheria?

JM - Daí eu escolheria o alemão.

Para Janete, o seu alemão é sua língua materna e, mesmo compreendendo a necessidade do inglês no mundo atual, se tivesse de escolher entre essas línguas, escolheria a 
língua que aprendeu de seus pais. Com isso poderíamos ter chegado ao fim de um impasse, se não fosse Janete tão diferente de Mateus e de Thamara.

Sobre a escola, Janete narra experiências semelhantes às de Zilma e fala também sobre a questão da vergonha que parece associar às atitudes dos colegas com relação às dificuldades para entender o português na escola. Diante de relatos assim, é difícil não perceber-se a importância de um tratamento adequado para a língua imigrante nessas localidades. Mas deveria este tratamento ser o mesmo reservado a outra língua estrangeira?

J - E lá você estudava com um monte de crianças que eram como você, todo mundo falava alemão, era isso?

JM - É, la na escolinha, até a quarta série, todo mundo era alemão, daí era fácil. Daí na hora que nos fomos ali pro Garcia, daí só ia três ou quatro lá da colônia que sabia falar em alemão, daí nos ia pro Garcia, os primeiros dias mesmo era difícil, a gente não conseguia falar quase com ninguém, ninguém falava com nós assim. Daí a gente teve que ficar mais na nossa turminha, não...

$\mathrm{J}-\mathrm{E}$ algum dia você sentiu, assim, fora essa questão de estar isolado, fazer parte de um grupo, isolado não sei bem se é a palavra, mas enfim, você ter o seu grupinho, fora isso, você sentia alguma espécie de constrangimento por falar alemão, você se sentia diferente por falar alemão, é ...

JM - No começo, a gente falava, mas falava escondidinho pra ninguém escutar, que a gente tinha bastante vergonha.

J - Vergonha do quê? lá da escola.

JM - Muita gente ficava rindo da gente quando a gente falava em alemão,

J - Por quê?

JM - Não sei o porquê. Eles ficavam rindo da gente, que ia, a gente era alemão, que não entendia...

J - Mas eles também são, não são?

JM - São alemão. Mas não sabem alemão.

(risos)

É neste ponto que percebemos nas palavras de Janete um tom de superioridade sobre os demais e a possibilidade de reversão de um constrangimento causado, ironicamente, pela própria língua. Saber alemão resgata do constrangimento por não saber português. Aqui estamos diante de um vínculo identitário perceptível que liga o falante a sua língua imigrante. Mas com relação a sua educação, Janete parece ter problemas mais sérios do que a escolha ficcional entre línguas estrangeiras na escola. Janete parou de estudar na oitava série porque não tinha como chegar à escola onde o curso médio é oferecido.

J - Então tem uma coisa estranha aí entre os alemães que sabem alemão e os alemães que não sabem alemão.

JM - É.

J - Você parou de estudar quando?

$\mathrm{JM}$ - Eu me formei na oitava série.

J - Na oitava série e aí você parou de estudar.

JM - Lá no Garcia só vai até a oitava e daí pra vim aqui no colégio em Angelina, não teve transporte pra nós vim, pra continuar a estudar. 


\subsubsection{Mateus Fuck e Janete Müller - 28 de julho de 2007.}

Sobre o alemão na comunidade, percebe-se um papel importante da igreja e cabe lembrar que o pastor da igreja de Palheiros é o professor de alemão do curso noturno que Mateus freqüenta. Diante do fato que Janete afirma entender tudo que é dito na "missa" e diante da garantia do Mateus que o alemão do pastor é padrão, ficamos inicialmente confusos. A realidade mais provável é que o pastor transite com fluidez pelos dois universos lingüísticos

JM - Tem uma igreja evangélica.

$\mathrm{J}-\mathrm{E}$ o culto é em alemão ou é em português?

JM - Depende. Às vezes eles fazem o culto em alemão, às vezes eles fazem em português. Que nem, as vezes de dois em dois meses, as vezes de três em três meses, lá na escolinha municipal, que daí o nosso pastor vem, pras pessoas mais idosas, ela dá, faz abrir a escola e ele dá um missa pros mais idosos, como a maioria é alemão, daí ele reza a missa toda em alemão. É bem interessante ver a missa rezada em alemão.

J - E o alemão que ele usa pra rezar a missa é o mesmo alemão que você fala em casa, é igual ou ...

JM - É o mesmo alemão.

$\mathrm{J}-\mathrm{E}$ absolutamente igual, você entende tudo que ele fala?

$\mathrm{JM}-$ Eu entendo tudo que ele fala.

J -Você entende o conceito de dialeto? Você já ouviu esse termo pra se referir ao alemão que as pessoas usam aqui?

JM - Ahã. Já.

$\mathrm{J}-\mathrm{E}$ você se entende como falante de dialeto?

$\mathrm{JM}-\mathrm{E}$.

$\mathrm{J}-\mathrm{E}$ o pastor então fala dialeto.

JM - Fala.

J - Não é o alemão, alemão, sei lá o quê, o alemão oficial?

JM - Não.

$\mathrm{J}-\mathrm{E}$ todo domingo ele faz um culto aqui então?

JM - Daí é na comunidade de Palheiros.

$\mathrm{J}-$ Certo.

J - Então você está dizendo, Mateus, que pastor que te dá aula de alemão é o mesmo pastor que reza a missa lá na igreja na comunidade de Palheiros.

M - Isso.

J - Só que a Janete está me dizendo que ele fala dialeto e você está me dizendo que ele ensina alemão.

$\mathrm{M}-\mathrm{E}$.

J- Mas ele ensina alemão ou ele ensina o dialeto, você sabe?

M - Ele ensina o alemão da Alemanha.

$\mathrm{J}$ - Ele ensina o alemão da Alemanha mas ele fala dialeto, ele sabe os dois

então?

$\mathrm{M}$ - Sabe.

J - Quando ele reza a missa, ele reza em dialeto e quando ele dá aula ele dá aula de alemão culto, é isso?

$\mathrm{M}$ - Isso.

J - Como é que você sabe que o alemão que ele te ensina é diferente do alemão que ele usa na igreja? Você reconhece os dois?

$\mathrm{M}$ - Algumas coisas assim.

$\mathrm{J}-\mathrm{Ah}$ é?

M - Ele tem apostila, a bíblia dele é da Alemanha, tem tudo assim.

$\mathrm{J}$ - Parece oficial?

$\mathrm{M}-\dot{\mathrm{E}}$.

(risos) 
$\mathrm{J}$ - Mas você reconhece algumas coisas?

M - Algumas coisas, sim.

Talvez a relação com o dialeto não seja diferente da relação que temos com as formas mais familiares de português que utilizamos somente em nossas casas ou das formas regionais que abandonamos, em maior ou menor grau, quando mudamos para outras regiões do país e que voltamos a utilizar quando retornamos à nossa origem. Ainda assim, estaríamos diante do fato de que mesmo não significando um risco para o dialeto, o alemão padrão é diferente e não é a língua materna dessas comunidades a quem cabe decidir se a sobrevivência de suas línguas maternas precisa de ajuda ou não. 


\section{CAPÍtulo 6 - CENTRO E PERIFERIA}

\subsection{Conceitos paralelos}

Para Derrida (1993, p.224), o centro desafia a própria estruturalidade de um sistema, permanecendo fora dele ao mesmo tempo em que exerce seu poder. Nossa proposta é que os termos centro e periferia sejam sobrepostos aos termos "poder central" e "elite regional", como propostos por David Laitin, em seu artigo "Language Games", de 1988, para que possamos analisar a questão do multilinguísmo por meio de um paralelo que reconhece maior dinâmica na relação entre as duas posições.

Os modelos de Laitin foram desenvolvidos para a compreensão de sistemas de contato entre apenas duas línguas, um paradigma de multilingüismo que poderia, até mesmo, sugestionar o legislador na direção de políticas que ignorem um fator extremamente importante de nossa realidade lingüística: a existência dos dialetos.

A figura a seguir ilustra os conceitos de "poder central" e de "elite regional" propostos por Laitin transpostos para os termos de "centro" e "periferia". Essa transposição é útil porque, para Laitin, os conceitos de "poder central" e de "elite regional" são fixos, o que nem sempre é verdade na realidade do contato lingüístico, onde em nosso caso específico, poderia até mesmo ocorrer um acúmulo de papéis.

Para a compreensão de nosso argumento é necessário que se compreenda que as posições de "centro" e "periferia" podem ser ocupadas por diferentes atores em diferentes momentos. Portanto, na ilustração que se segue, estão representadas as posições de "centro" e "periferia" de uma forma aberta onde a "periferia" com relação a um determinado "centro", pode em outro momento ocupar a posição de "centro" com relação a uma segunda "periferia". Para fins do nosso estudo, "centro" representa quem ocupa a posição "centro", e "periferia" representa quem ocupa a posição "periferia"; "centro" e "periferia" são, portanto, termos relativos. 


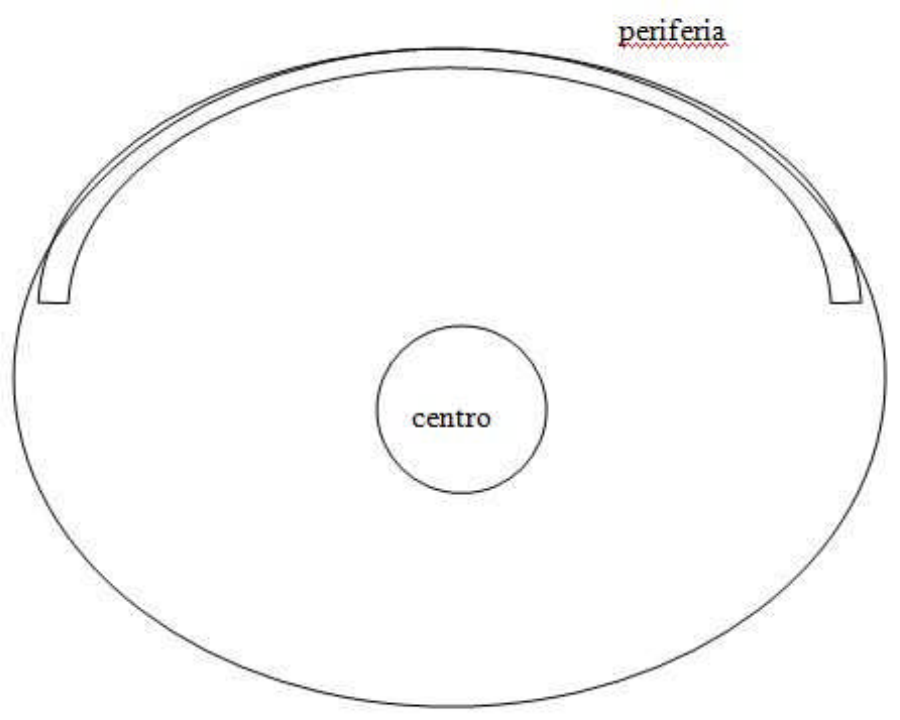

Figura 7 - Centro e Periferia

A proposta de políticas lingüísticas que visem revigorar línguas imigrantes pode ser compreendida como o reconhecimento da existência desses grupos de falantes, que a princípio ocupam a posição "periferia" em relação ao "centro", representado pelos proponentes dessas políticas. Este reconhecimento, no entanto, quando tratam-se das minorias lingüísticas dentro de nosso país, exige grande cautela, pois esse contingente que ocupa a posição "periferia" pode encerrar outras minorias. A simplicidade estrutural da periferia, como apresentada na Figura 1, é ilusória e só resiste ao olhar distante ou desatento, pois sob escrutínio, a periferia pode revelar pontos mais próximos e mais distantes do centro, podendo até mesmo transbordar a circunscrição da periferia conhecida em um cenário de contato lingüístico bastante dinâmico e complexo.

No plano prático, segundo Chambers (2002, p.79), “alguns indivíduos tornam-se participantes centrais e outros periféricos. Alguns separam-se do padrão, abraçando quaisquer oportunidades, de ascensão ou não, que a sociedade ofereça."

(...) some individuals become central members and others peripheral. Some break out of the pattern, grasping whatever opportunities the society provides for mobility upward or downward. (CHAMBERS, 2002, p. 79)

A maior implicação de uma posição periférica parece ser, a primeira vista, a associação a uma inferioridade com relação ao centro e resulta automaticamente em formas de discriminação, já que a estrutura é ditada do centro para a periferia. Ressalte-se que esta percepção de inferioridade pode não passar de uma percepção e que talvez o grupo às 
margens (no sentindo geométrico e não social do termo) possua mais força do que o grupo ocupando a posição central.

Diante do processo de globalização, todavia, é difícil supor-se que a periferia possa ser mais forte. Se tomarmos a relação entre centro e periferia como paradigma para a compreensão da questão do dialeto imigrante, veremos que o contexto de globalização gera aspirações de aproximação a uma posição central, não no sentido de uma "aproximação de um centro pré-existente", mas no sentido de que grupos periféricos possam vir a ocupar a posição "centro". Talvez seja esta a força por trás dos movimentos de grupos étnicos que não se contentam apenas com o realinhamento político, mas reivindicam para si status de nações autônomas.

No caso de nosso cenário lingüístico, o fenômeno da globalização pode estar por trás de boa parte do discurso construído em torno de nossas recentes políticas lingüísticas, pois, diante da globalização, a existência de línguas imigrantes pode passar a representar um recurso no processo de alavancagem da nação como um todo, em relação ao centro no cenário global. O discurso da língua imigrante como recurso, todavia, não parece originário do poder central no plano federal, mas de um plano intermediário representado, sobretudo, pela administração municipal dos municípios que abrigam esses falantes.

Do ponto de vista do poder central no plano da nação, todavia, tudo ao redor do centro é periférico. Assim, a origem regional da movimentação, por ocorrer no plano do município, pode favorecer a percepção por parte do poder central no plano da nação, de que a demanda provém da "periferia" quando pode estar emanando apenas de um grupo que é periférico em relação a esse centro. Essa mesma periferia, todavia, ocupa concomitantemente uma posição de "centro" com relação às comunidades por ela administradas, que constituem a periferia extrema do sistema.

Aqui percebemos que a periferia reconhecida pelo centro parece iniciar uma demanda por atenção decorrente da abertura de uma possibilidade de reconhecimento do valor de seu patrimônio. Se, por um lado, a percepção do desejo de participação mais central da nação no plano global representou um pequeno movimento na direção da periferia por abrir-lhe uma oportunidade de ver valorizado seu patrimônio linguiístico, por meio de diretrizes nacionais que possibilitaram a abertura desse espaço, essa periferia, por sua vez, iniciou um movimento correspondente na direção do centro a quem promete a revitalização de um recurso representado por línguas imigrantes, esquecendo-se que tais línguas imigrantes incluem dialetos que, até aqui, permaneceram debaixo do mesmo rótulo das variantes ditas padrão a 
eles correspondentes, possivelmente em decorrência do ciclo vicioso criado entre a ausência da demanda por diferenciação e o entorno que não percebia, ou não reconhecia, a diferença.

Com a introdução de um discurso modulador de atitudes lingüísticas que passa a promover a diversidade, a periferia das línguas imigrantes, percebida pelo centro, se faz representar, pelo menos inicialmente, pelos usuários da variante padrão, dentre os quais há fortes proponentes de esforços de padronização que podem colocar em risco a sobrevivência das formas dialetais.

Os grupos proponentes da padronização buscam o reconhecimento de seu próprio valor enquanto detentores de um recurso potencialmente mais útil para o centro (nação) por conta da globalização. Esse reconhecimento depende da percepção, por parte do centro da estrutura (nação), da existência de um patrimônio valioso, cujo valor decorre de uma escassez relativa que só pode ser reconhecida por meio de um discurso de diferenciação. Esses grupos proponentes da padronização necessitam, para impulsionar a sua causa, de números e de adesão que pretendem obter junto aos grupos de falantes de dialetos, cujas diferenças lingüísticas não estão sendo reconhecidas. Mas qual a importância disso, poderíamos perguntar? E isso poderia não ter importância nenhuma se esse processo padronizador não estivesse se encaminhando, em algumas regiões do país, na direção da obrigatoriedade da língua alemã, em paralelo à língua inglesa - algo que já ocorre, por exemplo, no município de Blumenau e que reside sobre a suposição de que a etnia da localidade seja majoritariamente de ascendência germânica e de que exista uma predominância da variante padrão, entre os falantes de alemão da região, justificando-se assim tal imposição curricular, esquecendo-se os proponentes dessas medidas que as regiões afetadas são habitadas por membros de outras etnias, além de falantes de dialetos que podem ou não ter interesse por essas iniciativas.

Ironicamente, nos parece que o preço a ser pago pelo reconhecimento de um grupo pode ser o do não reconhecimento de vários outros. Os proponentes dessas medidas poderiam argumentar, contudo, que as mesmas foram criadas com a maioria da população local em mente e teríamos de contra-argumentar que, se o objetivo é a busca da diversidade, o patrimônio cultural das minorias deveria ter o mesmo valor de outros patrimônios.

Nunca seremos capazes de atender a todos com base nas decisões criadas em torno de maiorias; agrava-se ainda mais tal situação quando a maioria não passa de uma percepção que, no caso das línguas imigrantes, pode não corresponder à realidade dos falantes. Diversidade não significa necessariamente desigualdade, muito embora, no caso dos dialetos, esses conceitos possam sobrepor-se, já que o dialeto é essencialmente uma língua de camponeses. Dessa forma, se existe uma sobreposição que correlaciona uma condição social 
com uma forma de linguagem, ainda teríamos de indagar sobre a maneira correta para encarar o problema.

A movimentação da periferia em direção ao centro ocorrerá, portanto, de forma não uniforme e contará possivelmente com resistências e dissidências. De certa forma, a periferia, enquanto conjunto, terá de se expandir para dar conta de um novo papel, ao mesmo tempo em que desempenha suas antigas funções; na prática isso acontece pela movimentação de alguns de seus membros enquanto outros são deixados para trás. Como afirma Hutcheon (1993, p.252), "o caráter provisório e a heterogeneidade contaminam quaisquer tentativas de enquadramento para que se chegue a uma coerência unificadora - formal ou temática".

Assim, enquanto os filhos rumam na direção do urbano e do novo, os mais velhos continuarão para trás, presos à lavra das terras. Ao movimento por parte dos que se movem (“periferia") na direção do urbano e do novo ("centro") corresponderá uma aparente movimentação do "centro" em direção à "periferia". Tal movimentação poderá ser expressa na forma de diversos tipos de incentivos que podem até incluir uma língua imigrante, diferente da variante falada pela "periferia", mas útil ao poder central em um esforço pelo seu deslocamento rumo ao centro de uma supra-estrutura globalizada que é apenas parcialmente visível da periferia. A aceitação de tal oferta poderá se dar sem maior grau de questionamento; talvez devido a uma confiança tácita naquilo que o "centro" possa oferecer aos seus integrantes; talvez devido a uma incapacidade da própria "periferia” em identificar a diferença..

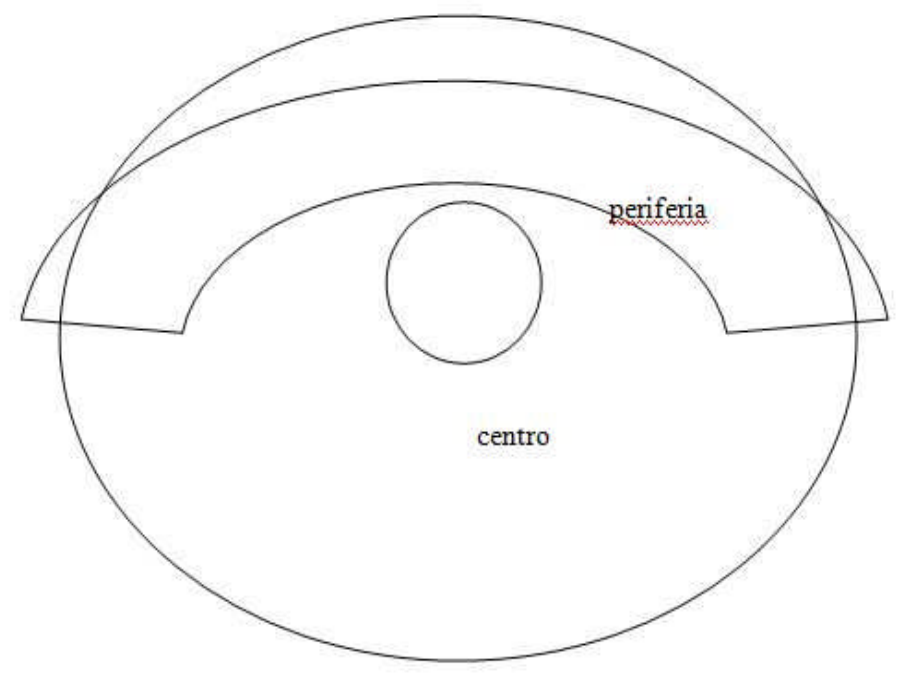


A figura acima representa essa expansão da periferia e o possível descolamento de sua retaguarda, com a conseqüente geração de uma nova periferia formada por aqueles que não se deslocaram em direção ao centro.

Como esse processo de movimentação é dinâmico, e como a "periferia" não é homogênea, o resultado é no mínimo o surgimento de vários níveis periféricos em relação ao centro, como ilustra a figura a seguir. Alguns falantes de dialeto abandonarão sua língua em prol da variante padrão; outros não farão esse movimento; outros ainda poderão ficar no meio do caminho. Entretanto, o esforço padronizador poderá gerar uma percepção de que aqueles falantes de dialeto que não aprenderam a variante padrão ou ficaram no meio do caminho são detentores de um patrimônio lingüístico inferior. $\mathrm{O}$ reconhecimento da diferença pode deixar de representar diversidade e pode voltar a implicar inferioridade.

Entre os possíveis efeitos práticos o centro poderia vir a exigir a contrapartida do investimento que fez na direção de periferia ao oferecer-lhe a variante padrão, convertendo a mesmo em mais uma exigência para o ingresso ou permanência no mercado de trabalho.

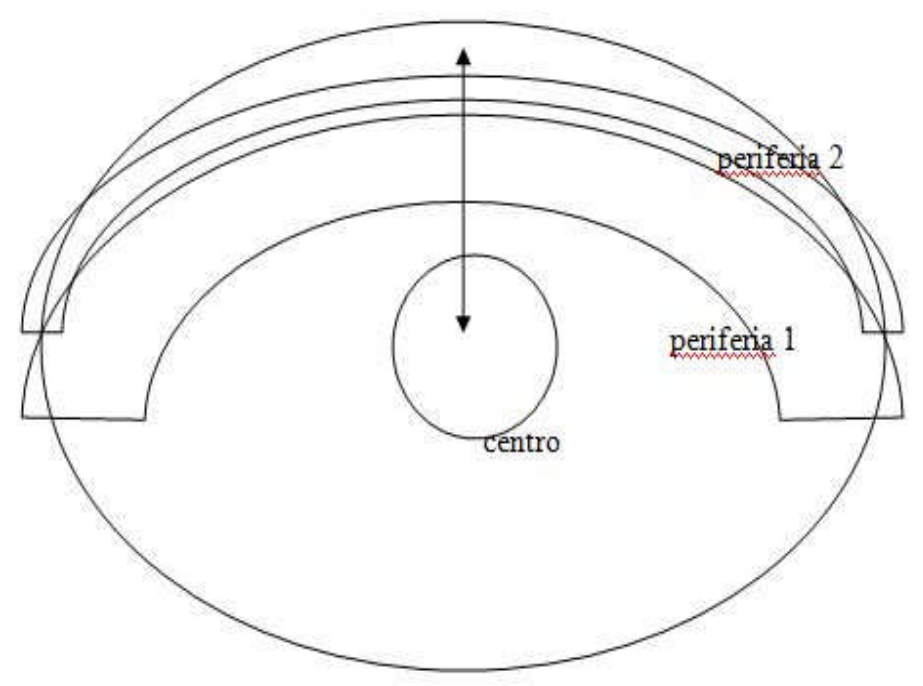

Figura 9 - O Descolamento das Periferias

Seria possível que a periferia se enxergasse como única porque "não fazia diferença", dentro da estrutura, ser diferente ou não. Em um sistema que não reconhece as diferenças, não há razão para que sejam manifestas. $\mathrm{O}$ reconhecimento da existência da periferia gera a própria necessidade de reconhecimento de diferenças e hierarquias dentro dessa periferia onde grupos hegemônicos tenderão a desejar a manutenção de sua própria posição de hegemonia, 
por meio do estabelecimento de marcadores claros, e nada poderia ser mais clara do que a imposição de uma norma sobre um grupo; imposição que implica a admissão de que existe todo um mundo além da norma e que agora ficará a ela submetida.

Em um mundo onde não "fazia diferença" se a língua era variante padrão ou dialeto, não é de surpreender que a política lingüística não fosse perceber as necessidades diversas dos diferentes grupos de falantes. Na medida em que a periferia se desmembra, em função da própria movimentação em direção ao centro, o contexto se modifica, ganhando complexidade. Se agora "faz diferença" para alguns, deveria "fazer diferença" para todos; caso contrário ocorrerá uma reprodução do não reconhecimento original da diferença, quando o centro entendia tudo ao seu redor como periférico e igual.

Embora "centro" e "periferia" possam parecer conceitos permutáveis com os conceitos de "urbano" e "rural", o primeiro par deriva essencialmente da estruturalidade do sistema, ao passo que o segundo abriga-se no indivíduo e herda suas ambigüidades, fato que pode ter impacto sobre as escolhas de assimilação que venham a ser feitas.

Talvez o processo de globalização tenha paralelos com o processo de urbanização, dependendo intrinsecamente dos indivíduos mais audazes ou ambiciosos que tomem para si o risco dos primeiros passos na direção do novo centro, ainda sem a certeza da reciprocidade do movimento. Dessa forma, não seria impossível conceber-se que, dentro desse novo modelo de competição, tenhamos indivíduos dentro da comunidade absolutamente dispostos a promover essa movimentação e investir nos recursos que sejam mais proveitosos para este fim e tendo por estratégia de jogo o retardamento da concorrência que competiria pelos novos espaços mais centrais. Assim pode depreender-se que a origem de um esforço padronizador já vem imbuída de um discurso de superioridade em que um grupo toma para si uma posição de superioridade que remete a periferia automaticamente a uma condição de atraso e submissão.

Em suma, parecem existir forças que atuam sobre o destino do artefato lingüístico, da mesma forma que atuariam sobre a sobrevivência ou obsolescência de qualquer outro artefato humano; forças que se fazem visíveis nas falas de nossos entrevistados Mateus Fuck e Thamara Dorigon, para quem o estilo de vida urbano e de usuários da internet parece mais ligado à realidade da língua inglesa que lhes chega pelo computador do que com a língua alemã da comunidade que os cerca. Parece-nos que chegamos a um momento histórico em que os indivíduos possuem grande autonomia para, desde que disponham da tecnologia e dos recursos necessários, modular a sua inserção no mundo de formas não vislumbradas até aqui e que ainda podem não ter sido bem compreendidas. 


\subsection{Línguas em competição no contexto globalizado}

Ao longo dos últimos anos temos testemunhado modificações no plano das políticas lingüísticas implementadas em regiões de nosso país que podem muito bem estar causando mais problemas do que gerando soluções, ainda que as percepções sobre tais políticas possam parecer, em um plano mais superficial, apontar em uma direção oposta. Parece-nos que muito do que vem sendo feito e proposto deriva de uma compreensão do problema que é, em grande parte, influenciada por um paradigma étnico e não toma como base as realidades lingüísticas das populações a serem atendidas por tais políticas. Parece-nos ainda haver um descompasso entre as propostas que vem se arrastando por mais de uma década e o movimento extremamente acelerado de globalização, enquanto processo de inserção de economias em desenvolvimento dentro de uma supra-estrutura centralizada em torno das economias mais desenvolvidas e que ditam as normas de tal inserção. Para que uma economia em desenvolvimento possa inserir-se na supra-estrutura globalizada, supõe-se a utilização de uma língua ou mais línguas que permitam tal inserção, daí a importância em nosso contexto do ensino de inglês e de outras línguas que possam servir a esse processo de inserção.

Apesar de poder parecer recente, o processo de globalização está alicerçado em tendências de padronização e homogeneização há muito conhecidas e que pressupõe, para a sua eficácia, uma universalização cristalizada em torno de um eixo. Na prática, globalização impõe o conceito de uma língua franca, ou na melhor das hipóteses de um conjunto de línguas francas. Nesse conjunto de línguas francas, a língua inglesa ocupa uma posição de destaque.

O Brasil, país cujo estágio de desenvolvimento o coloca em uma posição de desejar maior participação no cenário mundial, percebe essa posição de destaque da língua inglesa e a oferece na rede pública de ensino, desde o ensino fundamental, em caráter obrigatório.

Em paralelo a essa oferta de língua estrangeira em caráter obrigatório, a legislação abre a possibilidade de oferta de outras línguas estrangeiras. Diante dessa possibilidade, algumas localidades no sul do país têm implementado propostas para o ensino de outras línguas estrangeiras, conforme já foi visto.

Diante dessa dupla oferta, surge a possibilidade de competição entre essas duas línguas, ou seja, entre a língua inglesa e outra língua estrangeira que tenha sido escolhida com base na etnia de uma determinada comunidade. Um possível desdobramento dessa competição é a configuração de um cenário onde dois interesses distintos competem pela assimilação do falante potencial dessas línguas. Na prática, isso equivale a um cenário onde a 
revitalização da língua imigrante pode competir com o ensino da língua inglesa pelos recursos tanto de ensino como de aprendizado. Em outras palavras, o sistema terá de acomodar a nova oferta e arcar com seus custos de diversas ordens, ao mesmo tempo em que o estudante terá de hierarquizar os seus investimentos para o aprendizado dessas línguas.

Para a compreensão dessa competição, tomamos por base o trabalho de Laitin (1988), cujo paradigma de jogos para compreensão de cenário de bilingüismo pode ser expandido para uma reflexão sobre o contexto mais complexo do contato entre mais de duas línguas. $\mathrm{O}$ paradigma de Laitin é fundamentado na Teoria dos Jogos e analisa fatores de relevância por trás das escolhas dos falantes com relação às línguas que utilizam.

Todos os jogos, mesmo quando os jogadores têm chances iguais, são propostos por alguém. Aceitar o jogo, por outro lado, pode tanto resultar de não haver uma alternativa que não a de "participar do jogo", como derivar de uma aceitação genuína que exigiria confiança por parte dos jogadores de que o jogo precise ocorrer para o seu benefício; tal confiança depende, por sua vez, da percepção de que os possíveis prêmios valem o risco a ser corrido. No caso específico do aprendizado de uma língua estrangeiro, a percepção da utilidade da língua e os respectivos benefícios devem ser capazes de compensar o esforço despendido no aprendizado da mesma. Dessa forma, poderíamos compreender a opção do imigrante que, durante um período de guerra, por exemplo, não estimula os filhos a aprenderem a sua língua imigrante se essa estiver associada a um risco de discriminação. Da mesma forma a oferta de maior facilidade de inserção no mercado de trabalho pode representar um prêmio suficientemente compensador para justificar o aprendizado de uma língua estrangeira. 


\section{CAPÍTUlo 7 - OS Jogos DE DAVID LAITIN}

Neste capítulo passamos à exploração do valor dos jogos propostos por David Laitin na análise de nossa questão.

Laitin apresenta os conflitos entre os governantes centrais e as elites regionais como se fossem jogos de interesse. No caso de Laitin, os fatores focais do jogo são as línguas e as atitudes em relação a elas, pressupondo que os governantes centrais e as elites regionais falam línguas distintas. São pressupostos do jogo que: 1) há vantagem em poder usar sua própria língua; 2) há desvantagem em precisar aprender e usar a língua alheia; 3) há vantagem em se comunicar com seus subalternos (as elites regionais, no caso do governo central; o povo regional, no caso das elites regionais); 4) pode haver vantagem simbólica no uso da língua de mais prestígio; e 5) pode haver vantagem simbólica no uso da língua de identidade local.

Laitin descreve seis modelos típicos, que representam seis configurações diferentes de interesses e crenças dos participantes do jogo. O resultado de cada jogo (isto é, o resultado conjunto das decisões e os comportamentos de cada jogador) depende das avaliações de cada um sobre as próprias vantagens e desvantagens, em vista das suas crenças sobre as avaliações de vantagens e desvantagens que estão sendo feitas simultaneamente pelo seu oponente.

Como cada jogador ocupa uma posição distinta na rede de relações de poder, dificilmente o que é ideal para um será ideal também para o outro. O jogo consiste em procurar o ponto de equilíbrio que maximiza as vantagens e minimiza as desvantagens dos dois simultaneamente, dentro do contexto. Os jogos ainda se utilizam do conceito de pay-off, ou seja, um prêmio ou retorno de investimento. Esses seis jogos são chamados por Laitin de:

1. Jogo de racionalização do Estado

2. Jogo de construção de Nação

3. Jogo de reativação regional

4. Jogo de alteração espontânea regional

5. Jogo pós-colonial

6. Jogo de assimilação competitiva

Cada um desses modelos tem características particulares que serão descritas adiante. Em conseqüência dessas particularidades, há uma relação de pesos de valores que demonstra as posições de maior equilíbrio dentro do modelo em questão. Essa relação de pesos pode ser 
visualizada, com vantagem, como uma matriz. Para ilustrar como funcionam essas matrizes, podemos descrever a situação do jogo 1, a racionalização do Estado.

\subsection{Jogo de Racionalização do Estado}

O jogo de racionalização do Estado, ilustrado nas tabelas que se seguem, é caracterizado pela necessidade do poder central em racionalizar o estado, ou seja, para fazer com que o Estado funcione. A língua é o principal instrumento de racionalização do Estado. O modelo de racionalização do Estado pressupõe que a primeira preferência, do ponto de vista do poder central é de administrar na língua do poder central. Se essa configuração não é possível, a próxima preferência é pela administração temporária na língua regional enquanto as elites regionais aprendem a língua do poder central. Na seqüência o poder central prefere administrar na língua da região indefinidamente enquanto as elites regionais aprendem a língua da região. No quarto e último cenário, o governante é forçado a administrar indefinidamente na língua da região, dentro de um quadro em que a elite regional recusa-se a adquirir a língua do centro.

\begin{tabular}{cccc}
\hline & & \multicolumn{2}{c}{ Poder central administra na língua } \\
\hline & Aprendem & da Região & do Centro \\
\hline $\begin{array}{c}\text { Elites regionais } \\
\text { diante da língua do } \\
\text { Centro }\end{array}$ & Não aprendem & 2 & 4 \\
\hline
\end{tabular}

Tabela 1 - Preferências do poder central

Para a elite regional, a ordem de preferências é diferente. Do ponto de vista da elite regional, a primeira preferência seria de ser administrada na sua língua e não aprender a língua do centro, já que do ponto de vista da elite regional, não aprender nenhuma outra língua representa menor esforço. Isso explica, por exemplo, porque determinados contingentes preferem imigrar para os mesmos lugares, já que encontrarão as levas anteriores que falam o mesmo idioma, o que facilita a sobrevivência no novo lugar mesmo sem saber a língua estrangeira, ainda que apenas em um primeiro momento. Esse cenário não sendo possível, a próxima preferência da elite regional é ser administrada na língua regional enquanto aprende a língua do centro. Somente depois de esgotadas essas duas primeiras possibilidades, a elite regional aceitará a administração na língua do centro enquanto aprende essa língua. A situação menos desejável ocorre quando o centro administra na língua do centro que não é aprendida pela elite regional. 
Essas preferências são representadas na tabela abaixo pelos números de 1 a 4 , onde 4 representa a situação mais preferível.

Esses pesos podem ser visualizados distribuídos conforme a tabela 2:

\begin{tabular}{cccc}
\hline & & \multicolumn{2}{c}{ Poder central administra na língua } \\
\hline Elites regionais & Aprendem & da Região & do Centro \\
diante da língua do & Não aprendem & 3 & 2 \\
Centro & 4 & 1 \\
\hline
\end{tabular}

Tabela 2 - Preferências da elite regional

Na próxima tabela, podemos ver as preferências de ambos os jogadores agrupadas. Olhandose os pares de números, o número à esquerda representa a preferência relativa da linha, e o número à direita representa a preferência relativa da coluna. Ou seja, o primeiro número representa a preferência da elite regional e o segundo representa a preferência do poder central.

\begin{tabular}{cccc}
\hline & & \multicolumn{2}{c}{ Poder central administra na língua } \\
\hline & Aprendem & da Região & do Centro \\
Elites regionais & 3,2 & 2,4 \\
$\begin{array}{c}\text { diante da língua do } \\
\text { Centro }\end{array}$ & Não aprendem & 4,1 & 1,3 \\
\hline
\end{tabular}

Tabela 3 - Elite Regional x Poder Central

Como se pode ver pela tabela 3 , a situação de maior equilíbrio, que maximiza a soma das vantagens dos dois jogadores seria a em que o governo central administra na língua do Centro, com as elites regionais proficientes nessa língua. A soma dos valores individuais dessa opção é de 6 , enquanto as outras opções resultam uma soma de 5 ou de 4 . A tabela mostra claramente que, para atingir essa situação ótima, seria mais prudente para o governo central optar por administrar (temporariamente) na língua regional (valor 2) enquanto investe no aprendizado da língua central pelas elites (contando com o valor máximo de 5), do que continuar insistindo em administrar na língua central (valor 3), se as elites regionais mostrarem resistência ao seu aprendizagem (valor máximo de 4). 


\subsection{Jogo de Construção Nacional}

No jogo de construção nacional (LAITIN, 1988, p.292) existe o pressuposto de que as preferências mudam. Talvez a nação se construa de fato com o poder do centro se expandindo e com números maiores de indivíduos da região aprendendo a língua do centro, tornando-se burocratas, educadores, etc. Oportunidades no centro também tornar-se-iam viáveis atraindo membros da periferia.

Laitin propõe, nesse modelo, que as elites regionais e aqueles que tenham assimilado a cultura do centro iriam, no final, perceber suas línguas regionais como atrasadas e impróprias para negócios sérios, enxergando a administração na língua central como natural e correta mesmo quando algumas pessoas da região não a falam.

Diglossia, segundo Laitin, seria uma decorrência desse cenário (1988, p.293), quando os símbolos e estruturas de significado da língua original continuam a existir na poesia e preservados por filólogos na mesma medida em que números cada vez maiores de membros da comunidade adotam a língua do centro, remetendo a uma condição de assimetria onde assuntos de importância são tratados em uma forma "alta" e assuntos de natureza privada ou afetiva são tratados em uma forma "baixa".

No jogo de construção nacional, a elite regional perde sua posição mediadora conquistada no jogo de racionalização do estado porque as massas aprendem a língua do poder central e passam a valorizar essa língua mais do que a língua de sua região.

\begin{tabular}{cccc}
\hline & & \multicolumn{2}{c}{ Poder central administra na língua } \\
\hline $\begin{array}{c}\text { Elites regionais e as } \\
\text { massas diante da } \\
\text { língua do Centro }\end{array}$ & Aprendem & da Região & do Centro \\
\hline
\end{tabular}

Tabela 4 - Preferências das Elites Regionais e das Massas

Do ponto de vista da elite regional e das massas, a primeira preferência seria aprender a língua do centro e ser administrada nessa língua. Esse cenário não sendo possível, a próxima preferência da elite regional e das massas é ser administrada na língua regional enquanto aprende a língua do centro. Somente depois de esgotadas essas duas primeiras possibilidades, a elite regional e as massas preferirão a administração na língua do centro sem aprender a língua do centro. Essa preferência se explica pelo fato de a elite regional e as massas, ainda que não falando a língua do centro, continuam atribuindo à língua do centro maior valor. A situação menos desejável ocorre quando a elite regional e as massas são administradas na 
língua regional sem a possibilidade de aprender a língua do centro, configurando-se um cenário de exclusão.

\begin{tabular}{cccc}
\hline & & \multicolumn{2}{c}{ Poder central administra na língua } \\
\hline & & da Região & do Centro \\
\hline $\begin{array}{c}\text { Elites regionais e as } \\
\text { massas diante da } \\
\text { língua do Centro }\end{array}$ & Não aprendem & 2 & 4 \\
\hline
\end{tabular}

Tabela 5 - Preferências do Poder Central

No jogo de construção nacional, a primeira preferência, do ponto de vista do poder central é de administrar na língua do poder central com a elite regional e as massas aprendendo a língua do centro. Se essa configuração não é possível, a próxima preferência é pela administração na língua do centro sem que a elite regional e as massas aprendam a língua do centro. A próxima preferência do poder central é administrar na língua da região enquanto as elites regionais e as massas aprendem a língua do poder central. No quarto e último cenário, o governante é forçado a administrar indefinidamente na língua da região, sem que as elites regionais e as massas aprendam a língua do poder central.

$\mathrm{Na}$ tabela abaixo, podemos ver as preferências de ambos os jogadores agrupadas. Olhando-se os pares de números, o número à esquerda representa a preferência relativa da linha, e o número à direita representa a preferência relativa da coluna. Ou seja, o primeiro número representa a preferência da elite regional e o segundo representa a preferência do poder central.

\begin{tabular}{cccc}
\hline & & \multicolumn{2}{c}{ Poder central administra na língua } \\
\hline & & da Região & do Centro \\
$\begin{array}{c}\text { Elites regionais e as } \\
\text { massas diante da }\end{array}$ & Aprendem & 3,2 & 4,4 \\
língua do Centro & Não aprendem & 1,1 & 2,3 \\
\hline
\end{tabular}

Tabela 6 - Elites Regionais e as Massas x Poder Central

Como pode-se ver pela tabela, a situação de maior equilíbrio, que maximiza a soma das vantagens dos dois jogadores seria aquela em que o governo central administra na língua do Centro, com as elites regionais e as massas proficientes nessa língua. A soma dos valores individuais dessa opção é de 8 , enquanto as outras opções dão uma soma de 5 ou de 2. 


\subsection{Jogo de Reativação Regional}

Para o Jogo de Reativação Regional, Laitin propõe um cenário onde a racionalização do Estado gera condições para que se articule a sua própria antítese, o que pressupõe mudanças tanto das preferências do Estado como das preferências das elites regionais. Laitin argumenta que, em dado momento, o Estado irá buscar redução dos custos de obediência por meio da busca por apoio à sua autoridade (Laitin, 1988, p.293) e oferece como exemplo um cenário de escassez de trabalho onde o incentivo pela homogeneidade lingüística dentro de seu território serviria para conter o esforço subversivo da emigração. Para Laitin, a idéia de homogeneidade lingüística torna-se poderosa independentemente das motivações dos governantes. Quando a legitimidade do governante torna-se dependente da percepção de ganhos por parte das massas no plano do bem-estar social (welfare gains), o estado pode achar por bem garantir papéis mais destacados às línguas regionais, ou seja, o poder central "aceita" administrar algumas áreas na língua regional enquanto as massas e a elite regional assumem um compromisso de aprender a língua do poder central.

Laitin (1988, p.294) ainda aponta para o fato de que as massas politicamente mobilizadas na era moderna são particularmente abertas à reivindicação de privilégios e direitos perdidos e que as elites regionais podem se aproveitar da abertura de oportunidade para exigir que a administração e a educação sejam conduzidas na língua regional. Diante da força do poder central, ainda de acordo com Laitin, seria loucura abrir mão da língua de preferência do governante, mas as elites regionais, agora com vínculo eleitoral com as massas, poderiam vir a preferir resistência lingüística à dominação. Essas mudanças com relação ao Jogo de Racionalização do Estado são modeladas nas tabelas a seguir, que ilustram o Jogo de Reativação Regional.

\begin{tabular}{cccc}
\hline & & \multicolumn{2}{c}{ Poder central administra na língua } \\
\hline & & da Região & do Centro \\
\hline $\begin{array}{c}\text { Elites regionais e as } \\
\text { massas diante da } \\
\text { língua do Centro }\end{array}$ & Não aprendem & 4 & 2 \\
\hline
\end{tabular}

Tabela 7 - Preferências das Elites Regionais e das Massas

Pare compreendermos os pesos da tabela 7 é importante perceber que no Jogo de Reativação Regional, o processo de reativação da língua da região é concomitante com o processo de aprendizado da língua do poder central, mas em direções opostas. Ou seja, quanto mais alta a reativação (aprendizado) da língua regional, mais baixo o aprendizado da língua 
do poder central. Neste cenário, a primeira preferência do ponto de vista da elite regional e das massas é ser administrada na língua da região com esta sendo plenamente reativada (peso 4) e sem a necessidade de aprender a língua do centro. Esse cenário não sendo possível, a próxima preferência da elite regional e das massas seria ser administrada na língua da região com o compromisso de aprender a língua do poder central em algum momento, mas com a língua da região ainda gozando alto status por ser a língua usada na administração (peso 3). Nenhuma dessas possibilidades ocorrendo, ou seja, o poder central não aceitando administrar na língua da região, a elite regional e as massas aceitariam a administração na língua do poder central enquanto aprendem essa língua (peso 2), mas ainda com a possibilidade mínima de reativar a língua da região. No pior cenário para as massas e a elite regional, o poder central administra na língua do centro e não há possibilidade de reativação da língua da região (peso 1) o que implicaria o aprendizado da língua do poder central pela elite regional e as massas.

\begin{tabular}{cccc}
\hline & & \multicolumn{2}{c}{ Poder central administra na língua } \\
\hline & & da Região & do Centro \\
\hline $\begin{array}{c}\text { Elites regionais e as } \\
\text { massas diante da } \\
\text { língua do Centro }\end{array}$ & Aprendem & 3 & 4 \\
\hline
\end{tabular}

Tabela 8 - Preferências do Poder Central

No jogo de reativação regional, a primeira preferência do ponto de vista do poder central é administrar na língua do centro com a elite e as massas aprendendo a língua do centro. O poder central não reconhece a língua da região, impondo a administração na sua língua (peso 4). Ou seja, do ponto de vista da administração, não ocorre reativação da língua da região e todos aprendem a língua do centro. Este cenário não sendo possível, o poder central aceita administrar na língua da região durante o processo de reativação desta pelas massas e pela elite regional, porém tem como horizonte o compromisso da elite regional e das massas de aprender a língua do centro em algum momento (peso 3). Esgotadas estas possibilidades, o poder central preferirá administrar na língua do centro mesmo que as elites regionais e as massas não falem essa língua e estejam ainda tentando reativar a língua da região. O poder central assume o risco de administrar numa língua que as massas e a elite regional não falam (ameaçam não aprender) por entender que esta ameaça não se concretizará, e as massas e a elite regional acabarão aprendendo a língua do poder central (peso 2). No pior cenário para o poder central, este é forçado a administrar na língua da região 
indefinidamente, com a elite regional e as massas não aprendendo a língua do poder central e reativando plenamente a língua da região (peso 1).

\begin{tabular}{cccc}
\hline & & \multicolumn{2}{c}{ Poder central administra na língua } \\
\hline & & da Região & do Centro \\
Elites regionais e as & Aprendem & 4,3 & 2,4 \\
massas diante da & Não aprendem & 3,1 & 1,2 \\
língua do Centro & & & \\
\hline
\end{tabular}

Tabela 9 - Elites Regionais e as Massas x Poder Central

Como se pode ver pela tabela acima, a situação de maior equilíbrio, a qual maximiza a soma das vantagens dos dois jogadores, seria aquela em que o poder central administra na língua da região enquanto esta é reativada, porém, com o compromisso de a elite regional e as massas aprenderem a língua do poder central. A soma dos valores individuais dessa opção é 7.

\subsection{Jogo de Alteração Espontânea Regional}

O jogo de alteração espontânea regional (tipping game) é essencialmente uma situação em que temos a reversão na tendência de uma variável após atingirmos certo ponto ao longo do eixo de outra. Na prática pode ser resumido a um cenário onde o valor de um recurso oscila por conta de sua escassez ou abundância. Por seu pouco valor, o recurso pode vir a ser gradualmente abandonado até o ponto em que se torne escasso e, por conta de sua escassez, volte a ter valor. Jogos de alteração regional poderiam, teoricamente, se suceder em ciclos sucessivos de desvalorização e revalorização do recurso.

Na figura a seguir (LAITIN, 1988, p. 295), "C" representa a língua do centro e "R" representa a língua regional. A linha "CC" representa o prêmio para o falante regional pela adoção da língua do centro, enquanto a linha "RR" representa o prêmio associado aos diferentes graus de manutenção da língua regional por parte do falante. Ainda na mesma figura, as posições de “0” a "100” representam o grau de adesão dos falantes. Segundo Laitin (1988, p. 295) “o ponto “0” representa a situação em que todos os rebeldes regionais desistem de aprender e usar a sua língua (R) em favor da língua do centro (C)" e "a linha CC representa o prêmio para qualquer indivíduo na região por escolher a língua do centro." Como podemos verificar, o prêmio inicia com um valor alto, declina ao longo do gráfico, readquirindo algum valor próximo a “100”" 


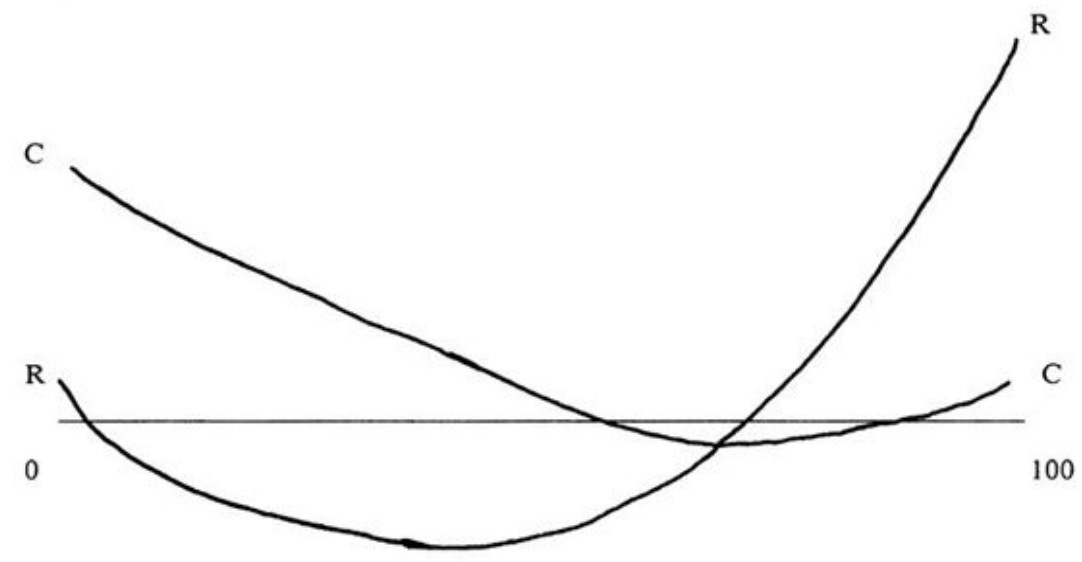

Figura 10 - Jogo de Alteração Espontânea

Ainda segundo Laitin (1988, p. 295) “o jogo de alteração inicia em decorrência do movimento de reativação regional" quando "o status quo é próximo a zero, representando um resultado deficiente". Ou seja, no início do jogo, a língua regional (R) tem falantes mas não tem status. Laitin acrescenta que "o problema político é como transpor o ponto de reversão quando não é racional para o indivíduo mudar o seu comportamento lingüístico" e que “ativistas regionais compreendem esse dilema, sabendo que um equilíbrio satisfatório somente será atingido se esses encontrarem uma maneira de recompensar os falantes que primeiro se movimentarem na direção da reativação e punir os que não alteram o seu comportamento".

Laitin (1988, p. 296) estipula que "através da ação política, as posições "1" e "2" das elites regionais" trazidas da tabela 9, que é a resultante do jogo de reativação regional, "trocariam de posição", o que é fácil de compreender-se justamente por se tratar de um jogo de reversão entre a língua da região e a língua do centro, o que explica as posições em que as elites regionais não aprendem a língua do centro como posições de equilíbrio a despeito da pontuação menor. Trata-se de um jogo ao contrário, onde ganha quem tiver menos pontos.

As novas posições são ilustradas na tabela abaixo: 


\begin{tabular}{cccc}
\hline & & \multicolumn{2}{c}{ Poder central administra na língua } \\
\hline & & da Região & do Centro \\
\hline $\begin{array}{c}\text { Elites regionais e as } \\
\text { massas diante da } \\
\text { língua do Centro }\end{array}$ & Não aprendem & 4,3 & 1,4 \\
\hline
\end{tabular}

Tabela 10 - Elites Regionais e as Massas x Poder Central (jogo de alteração)

Como podemos perceber, as pontuações das duas células correspondentes ao não aprendizado da língua do centro por parte das elites regionais somam ambas 4 pontos, contra 7 e 5 pontos nas células que correspondem a tal aprendizado. Isso seria um empate entre as duas posições de valor 4 caso não compreendêssemos que a posição “2,2” encerra potencialmente uma posição de menor conflito. Segundo Laitin (1988, p. 296) "um acordo (por meio de contrato) poderia trazer ambos os lados a aceitar o resultado eficiente de '4,3"' e acrescenta, retomando o jogo de reativação regional, que "esse não pode ser bem sucedido a menos que por meio de ação política, em que a região possa criar uma mudança no que seriam as preferências individuais dos cidadãos comuns."

Na prática, o acordo de que fala Laitin significa que, por de decisão política, a língua da região será a língua do centro naquela região. No jogo de alteração, pela própria natureza do jogo, os resultados são invertidos, ou seja, as células vencedoras serão as que tiverem a menor soma. Portanto, a célula "4,3" não seria vencedora no jogo de alteração regional. As duas posições possíveis seriam 3,1 e 2,2 por conterem a pontuação mais baixa, com o último par representando o melhor resultado em função de melhor distribuição dos pontos.

Basicamente, a diferença entre o jogo de reativação regional e o jogo de alteração regional é que no primeiro houve um acordo por meio de ação política, que é representado nas tabelas por meio da inclusão da possibilidade do jogo ser vencido sempre nas células de maior pontuação.

\subsection{Jogo Pós-Colonial}

O próximo modelo de Laitin é chamado de jogo pós-colonial e não nos parece particularmente útil para a compreensão de nosso contexto senão pelo fato de que atesta a capacidade de elites regionais em afirmarem as suas línguas, assegurando-lhes status quase oficial, a partir de um modelo de jogo que seria anômalo com relação ao modelo de racionalização nacional, já que nos contextos pós-coloniais, a língua colonial permaneceu, de modo geral, contestada pelos contingentes colonizados. 
It is often said that the large number of languages within these states makes a policy of linguistic imposition much more difficult. But any reading of European history will show a large number of regional languages that became challenged by the language of the bureaucratic state. The number of languages in India or Nigeria alone cannot explain why postcolonial elites could not rationalize language in the same manner as did early modern kings in western Europe. (LAITIN, 1988, p. 296)

Ao afirmar que apenas os números de línguas na Índia ou na Nigéria não são capazes de explicar porque as elites pós-coloniais não tiveram o mesmo êxito de racionalização lingüística obtido pelos reis modernos da Europa ocidental, Laitin deixa aberta a possibilidade de considerações que incluem o desejo de racionalização por parte do subordinado. Um fator que parece ter existido na Europa ocidental onde o súdito desejava a proteção e os privilégios advindos da nova condição em uma situação talvez paralela à situação do imigrante que deseja fazer parte do novo coletivo. No contexto pós-colonial, as motivações são outras e o desejo primordial é o de separação daquilo que representara a opressão imposta de fora para dentro.

A tabela que se segue ilustra o jogo pós-colonial do ponto de vista do colonizador:

\begin{tabular}{cccc}
\hline & \multicolumn{2}{c}{ Colonizado } \\
\hline & & Língua do & Língua do \\
& Aprendem & 3 & 4 \\
Colonizador & Não aprendem & 2 & 1 \\
\hline
\end{tabular}

Tabela 11 - Preferências do Colonizador

O jogo pós-colonial pressupõe que a primeira preferência, do ponto de vista do colonizador é de administrar na língua do colonizador. Se essa configuração não é possível, a próxima preferência é pela administração na língua do colonizado, temporariamente, enquanto o colonizado aprende a língua do colonizador. A próxima preferência do colonizador é administrar indefinidamente na língua do colonizado sem que esse aprenda a língua do colonizador. A hipótese menos preferível seria de administrar indefinidamente na língua do colonizador sem que o colonizado jamais aprenda a língua do colonizador, posição essa última de extrema desvantagem tática do ponto de vista da racionalização do estado, já que não existe comunicação direta entre as partes.

A tabela a seguir ilustra o jogo pós-colonial do ponto de vista do colonizado: 


\begin{tabular}{cccc}
\hline & \multicolumn{2}{c}{ Colonizado } \\
\hline & & Língua do & Língua do \\
Colonizador & Aprendem & Colonizado (Região) & Colonizador (Centro) \\
& Não aprendem & 4 & 3 \\
\hline
\end{tabular}

Tabela 12 - Preferências do Colonizado

Para o colonizado, a ordem de preferências é diferente. Do ponto de vista do colonizado, a primeira preferência seria de ser administrado na sua língua local e não aprender a língua do colonizador. Esse cenário não sendo possível, a próxima preferência do colonizado, segundo Laitin (1988, p. 297), é ser administrado na língua do colonizador, enquanto aprende a língua do colonizador. Em seguida, teremos a preferência 2, em que o colonizado é administrado na língua do colonizado enquanto aprende a língua do colonizador. A situação menos desejável ocorre quando o colonizador administra na língua do colonizador sem que o colonizado aprenda a língua do colonizador.

Muito embora essas posições reflitam os pesos no jogo pós-colonial, como descrito por Laitin (1988, p. 297), não concordamos com a escala de preferências dessa última tabela. Parece-nos mais lógico que as posições 2 e 3 fossem alternadas, para refletir a preferência 3 como sendo a preferência do colonizado em ser administrado na língua do colonizado enquanto aprende a língua do colonizador. Laitin, todavia, não apresenta argumentos para sua escolha e a única explicação que parece lógica seria a de que, em virtude da imposição da situação colonial, o colonizado revertesse sua escolha para minimizar a fricção com o colonizador.

Na próxima tabela, podemos ver as preferências de ambos os jogadores agrupadas. Olhando-se os pares de números, o número à esquerda representa a preferência relativa da linha, e o número à direita representa a preferência relativa da coluna. Ou seja, o primeiro número representa a preferência do colonizador e o segundo representa a preferência do colonizado.

\begin{tabular}{cccc}
\hline & \multicolumn{2}{c}{ Colonizado } \\
\hline & & Língua do & Língua do \\
& Aprendem & Colonizado (Região) & Colonizador (Centro) \\
Colonizador & Não aprendem & 2,2 & 4,3 \\
& & 2,4 & 1,1 \\
\hline
\end{tabular}

Tabela 13 - Colonizador x Colonizado 
Como se pode ver pela tabela, a situação de maior equilíbrio, que maximiza a soma das vantagens dos dois jogadores seria aquela em que o colonizador administra na língua do colonizador, com o colonizado sendo capaz de falar essa língua. A soma dos valores individuais dessa opção é de 7.

\subsection{Jogo de Assimilação Competitiva}

O modelo final é o jogo de assimilação competitiva. Para Laitin (1988, p. 297), este modelo de jogo ocorre essencialmente quando da entrada de um estado em seu estágio industrial que, em uma primeira fase, por conta de novas demandas por mão-de-obra, testemunhará "uma migração do campo para a cidade que raramente impõe um desafio lingüístico para a racionalização do estado".

A situação seria diferente para os "Estados que contam com imigrantes internacionais" que poderiam ser vistos como constituindo um "dilúvio lingüístico", ainda segundo Laitin. É nesse cenário, em que o Estado necessita contar com mão-de-obra de imigrantes estrangeiros, que essa imigração torna-se preocupante para o poder central, pois pode colocar em risco o "consenso lingüístico" conquistado no período da racionalização do estado.

Moving back to the historical development of language, from state rationalization to state challenging or nation building, we can identify another source of linguistic pressure against the forces of state rationalization. As a state enters the modern industrial age, there is an increasing need for labor. First there is a rural to urban migration, which rarely poses a linguistic challenge. But those states that rely on international migrants immediately face what many see as a linguistic deluge. State elites, most commonly school administrators, begin to worry whether the linguistic "consensus" of the state rationalization period will hold together. (LAITIN,1988, p. 297)

O jogo de assimilação competitiva ocorre entre um imigrante "A" e um imigrante "B" em função de suas preferências pela manutenção ou pelo abandono da língua imigrante. Tenhamos em mente que o objetivo de cada jogador é ser assimilado.

A tabela abaixo ilustra as preferências do imigrante "B":

\section{Imigrante "A"}

Aprende a língua do Não aprende a língua centro do centro

Aprende a língua do centro

Imigrante "B"
2

4

do centro 
Tabela 14 - Preferências do Imigrante "B"

Do ponto de vista do imigrante "B", a primeira preferência seria de aprender a língua do centro, com o imigrante "A" não aprendendo essa língua. Esse cenário não sendo possível, a próxima preferência do imigrante "B" seria não aprender a língua do centro ao mesmo tempo em que o imigrante "A" também não aprende essa língua. A próxima preferência para o imigrante " $\mathrm{B}$ " seria de aprender a língua do centro com o imigrante "A" também aprendendo essa língua. A situação menos desejável para o imigrante "B" ocorre quando ele não aprende a língua do centro mas o imigrante "A" a aprende.

A tabela a seguir ilustra as preferências do imigrante "A":

\begin{tabular}{|c|c|c|c|}
\hline & & \multicolumn{2}{|c|}{ Imigrante "A" } \\
\hline & & $\begin{array}{l}\text { Aprende a língua do } \\
\text { centro }\end{array}$ & $\begin{array}{c}\text { Não aprende a língua } \\
\text { do centro }\end{array}$ \\
\hline \multirow[b]{2}{*}{ Imigrante "B" } & $\begin{array}{l}\text { Aprende a língua do } \\
\text { centro }\end{array}$ & 2 & 1 \\
\hline & $\begin{array}{c}\text { Não aprende a língua } \\
\text { do centro }\end{array}$ & 4 & 3 \\
\hline
\end{tabular}

Tabela 15 - Preferências do Imigrante "A"

Do ponto de vista do imigrante "A", a primeira preferência seria de aprender a língua do centro, com o imigrante "B" não aprendendo essa língua. Esse cenário não sendo possível, a próxima preferência do imigrante "A" seria não aprender a língua do centro ao mesmo tempo em que o imigrante "B" também não aprende essa língua. A próxima preferência para o imigrante " $A$ " seria de aprender a língua do centro com o imigrante "B" também aprendendo essa língua. A situação menos desejável para o imigrante "A" ocorre quando ele não aprende a língua do centro, mas o imigrante "B" a aprende.

$\mathrm{Na}$ tabela abaixo, podemos ver as preferências de ambos os jogadores agrupadas. Olhando-se os pares de números, o número à esquerda representa a preferência relativa da linha, e o número à direita representa a preferência relativa da coluna. Ou seja, o primeiro número representa a preferência do imigrante " $B$ ", e o segundo representa a preferência do imigrante "A". 


\section{Imigrante " $A$ "}

\begin{tabular}{cccc}
\hline & $\begin{array}{c}\text { Aprende a língua do } \\
\text { centro }\end{array}$ & $\begin{array}{c}\text { Aprende a língua do } \\
\text { centro }\end{array}$ & $\begin{array}{c}\text { Não aprende a língua } \\
\text { do centro }\end{array}$ \\
Imigrante "B" & $\begin{array}{c}\text { Não aprende a língua } \\
\text { do centro }\end{array}$ & 1,4 & 4,1 \\
\hline
\end{tabular}

Tabela 16 - Imigrante "B" x Imigrante "A"

Na tabela acima, a célula com a pontuação mais alta, que contém o par "3,3", é improvável dada a própria situação do imigrante, que estará inevitavelmente sujeito aos esforços do poder central para assimilar esse imigrante. Na prática, a posição "3,3” estaria invertida com a posição "2,2", ou seja, todos aprendem a língua do centro. As posições "1,4" e "4,1" ilustram o mesmo problema: escolhas hipotéticas que não ocorrem na realidade porque cada imigrante pode preferir que o outro não aprenda a língua do poder central, mas nada pode fazer para impedir esse aprendizado por parte de adversário. 


\section{CAPÍTULO 8 - TEORIA DOS JOGOS E DIALETO}

\subsection{Participação na região versus participação global}

Qual a diferença entre o modelo de construção nacional e um novo modelo onde a busca por hegemonia regional ocorre em função de poder econômico? A resposta fica por conta do fato de que, da maneira proposta originalmente, uma situação como a encontrada atualmente na República da Geórgia, onde periferias separatistas buscam hegemonia por meio de independência, seria analisada somente pela perspectiva de separação da supra-estrutura original para a constituição de um estado nacional; se a hegemonia seria buscada por meio de independência concreta ou por meio de afirmação econômica parece ser somente uma variável do grau de utilidade da supra-estrutura e dos respectivos prêmios associados a tal utilidade. O prêmio a ser oferecido por uma supra-estrutura percebida como obsoleta tende à zero. A supra-estrutura obsoleta oferece prêmio baixo e não mais justifica a adesão; o resultado: uma busca por independência concreta. O novo modelo exige, todavia que se compreenda que uma ruptura com uma supra-estrutura obsoleta é possivelmente acompanhada pelo desejo de constituição de uma identidade nacional porque essa nova identidade permitiria a inclusão direta, não intermediada, em uma nova supra-estrutura.

Existe, portanto um paralelo de dois jogos nos quais duas supra-estruturas competem pelos recursos de construção identitária da mesma periferia. Dessa forma, a obsolescência de uma estrutura parece vinculada ao surgimento de uma nova que toma seu lugar, gerando um sistema de jogos paralelos enquanto a estrutura obsoleta não sucumbir completamente. Esse paralelo parece válido também na situação da periferia usuária de dialetos que podem, simplesmente, buscar alinhamento direto com a supra-estrutura que represente o futuro, ao invés de aliar-se a uma elite regional cujo reconhecimento da periferia pode ter vindo tarde demais para reverter percepções de obsolescência. Resta-nos, diante das queixas de abandono do patrimônio ancestral, nítidas em Oliveira (2003), perguntar qual das estruturas atingirá a obsolescência mais rapidamente. No nosso caso específico, o que trará menos benefícios a partir de agora? A manutenção do alinhamento com os interesses do poder central ou o alinhamento mais recente com os interesses da elite regional que promete capitalizar os recursos da comunidade com promessas melhores condições para seus integrantes. A resposta poderia parecer simples se não fosse a realidade de que o alinhamento com o poder central também traz seus prêmios e se os integrantes da região não estivessem, assim como 
todas as demais pessoas subordinadas ao Poder Central, subordinados também aos interesses de um processo de globalização que também oferece seus prêmios que vão de maior projeção dentro da própria estrutura do Poder Central, talvez participando de organizações mundiais, até a possibilidade de emigrar e vender mão-de-obra especializada fora do próprio país.

Em termos práticos, no que se refere à língua, diante de percepções de obsolescência, tanto com relação ao dialeto quanto com relação à variante padrão, seria até mesmo possível que a periferia abandonasse o dialeto sem adotar a variante padrão, mesmo apesar dos esforços pela promoção dessa variante, e adotasse diretamente uma língua percebida como mais útil. Essa posição, embora possa parecer improvável diante do vínculo cultural dos falantes, foi encontrada na prática durante nossa coleta de dados. Seria igualmente possível que a insistência pela preservação do dialeto e/ou adoção da variante padrão servissem apenas para nutrir ainda mais possíveis ressentimentos dentre os jovens das comunidades que agora poderão ser forçados a estudar a língua. Cabe aqui lembrar que, de acordo com os dados, existe também uma atitude negativa, por parte de alguns jovens, com relação à língua dos mais velhos.

Partindo-se da premissa da existência da possibilidade de um encadeamento dos centros de uma estrutura como nos fala Derrida, onde um centro pode vir a substituir outro, podemos começar a pensar em um modelo mais complexo de jogo que possa incorporar o elemento do dialeto em suas relações com um ou mais centros simultâneos cujos interesses podem ser ou não coincidentes a cada dado momento do jogo.

(...) the whole history of the concept of structure, before the rupture I spoke of, must be thought of as a series of substitutions of center for center, as a linked chain of determinations of the center. Successively, and in a regulated fashion, the center receives different forms or names. (DERRIDA, 1993, p. 225)

Desta forma, esgotada a análise das implicações dos modelos de jogos disponíveis, passamos à análise da questão do dialeto diante de forças paralelas de assimilação e onde a posição dos jogadores é relativa em relação aos outros, podendo a posição central em relação a um constituir posição periférica com relação a outro. 


\subsection{Um jogo complexo}

É importante lembrar que a proposta de um modelo de jogo para analisar fenômenos sociais é uma ferramenta que visa mapear de maneira mais concreta o terreno da realidade estudada. O modelo que estamos propondo não tem a pretensão de representar a realidade estudada, mas apenas de facilitar a reflexão sobre variáveis que afetam os comportamentos e as atitudes lingüísticas dos jogadores. Para tanto, alguns pressupostos - que efetivamente constituirão as regras desse jogo - devem ser estabelecidos.

O primeiro pressuposto é o de que há três jogadores representados. Um dos jogadores é o falante de dialeto, que tem tal dialeto por língua materna, independentemente do grau de domínio que venha a ter das outras línguas com as quais esteja em contato. As comunidades de falantes de dialetos incluem falantes de vários tipos, desde o falante que só fala dialeto até o que é completamente bilíngüe em dialeto e em português. Outro jogador é a elite regional, que é constituída por indivíduos que já passaram pelo processo de assimilação e falam português, podendo falar tanto a variante padrão correspondente ao dialeto como o próprio dialeto. $\mathrm{O}$ terceiro jogador é o poder central, compreendido como a administração da nação como um todo e que tem por um de seus objetivos primordiais a racionalização do Estado e que pressupõe uma língua nacional como veículo de tal racionalização. Os modelos de jogos propostos por Laitin (1988) supõem a participação de apenas dois jogadores, já que Laitin analisara situações de contato entre duas línguas, uma sendo a língua nacional do poder central e a outra uma língua minoritária da elite regional. Em virtude de percebermos em nosso cenário a complexidade imposta pela existência de dialetos, que não são necessariamente reconhecidos pela elite regional ou pelo poder central, resta o problema de como o jogo será articulado já que teremos três jogadores.

A primeira pergunta que devemos responder é se há possibilidade para um único jogo com três jogadores, ou se a realidade é a da alternância de dois jogos de dois jogadores, ocorrendo em paralelo. Aplicando-se o princípio de que o interesse pela racionalização do Estado é primordial para o poder central (LAITIN, 1988), chegaremos à conclusão que a hipótese de dois jogos em paralelo parece mais realista diante de duas estruturas exigindo racionalização ao mesmo tempo.

Partiremos ainda do pressuposto que, para efeito desse jogo, diante da realidade de um dialeto como língua materna, todas as línguas, que não o dialeto, são segunda-língua e que oferecem, cada uma delas, vantagens e desvantagens diferentes. 
Outro pressuposto é que a aquisição da variante padrão não necessariamente substitui o dialeto materno, tornando a variante padrão uma segunda língua.

É útil ainda pressupor, para efeito desse jogo, que língua estrangeira e segunda língua são aqui equivalentes uma vez que, diante da globalização, o ensino dessas línguas na atualidade incorpora a promessa de que venham de fato a ser utilizadas pelos falantes, em maior ou menor grau, em seus universos de trabalho, por exemplo. Dessa forma, o inglês como língua estrangeira, por exemplo, possui tanto potencial para segunda língua quanto o alemão padrão, já que a promessa é de que ambos serão úteis como instrumentos reais de comunicação no dia-a-dia profissional no mundo globalizado.

Ainda sobre a terminologia do jogo, para o poder central, a periferia é a elite regional, posição facilmente demonstrável já que o dialeto é ignorado pelas políticas lingüísticas sendo implantadas. Para o poder central, a periferia visível é a elite regional. Para a elite regional, a periferia de falantes de dialeto também parece invisível. Apesar de sua existência transparecer nos dados coletados, ela não é mencionada, pelo menos em termos específicos, para fins de política lingüística, apesar de ser reconhecida em estudos acadêmicos. Para a elite regional, para efeito desse jogo, portanto, existe uma periferia que é o falante de dialeto. As políticas linguiísticas que ora afetam as regiões que englobam comunidades falantes de dialetos têm sido estipuladas, no nível municipal por conta de uma identificação cultural com raízes imigrantes. Assim, as políticas emanam do plano da elite regional, não necessariamente representando uma extensão de políticas do Poder Central, mas, simplesmente, preenchendo lacunas existentes. Ao mesmo tempo, com relação às bases dessas comunidades imigrantes, o governo municipal, ao exercer seu poder legislador, ocupa a posição relativa de "poder central" com relação à essa "periferia" de comunidades imigrantes. Portanto, os jogadores serão identificados como "periferia", "elite regional" e "poder central", compreendendo-se que a elite regional ocupará, em um dos jogos, o papel de periferia e em outros, papel de poder central, por conta de sua posição de mediação.

Será necessário estabelecer um quadro com relação à hierarquia de preferências, em que o falante de dialeto que só fala dialeto iria, preferencialmente, não aprender uma outra língua. No nosso contexto, entenderemos que "preferência" é uma função do esforço e dos recursos despendidos na aquisição de outras línguas. Também é importante ressaltar que, para efeito do estabelecimento das preferências, não consideramos a dimensão do custo/benefício. A elite regional e o poder central não têm garantia de que o investimento no ensino resultará no correspondente aprendizado e no retorno desse investimento. De forma semelhante, o retorno do investimento feito pelo aprendiz não pode ser assegurado. Os riscos e os custos, no 
entanto, são conhecidos e concretos para todos os jogadores, já que os esforços e os investimentos terão que ser feitos por todos os jogadores, independentemente de resultados.

O próprio fato da existência de falantes de dialeto somente, ou cujo domínio do português seja muito restrito, reforça a idéia introduzida por Laitin (1988) de que existe, pelo menos para alguns falantes, a preferência pela sua própria língua materna, independentemente de sua inserção em um contexto multilíngüe. Se a preferência por não aprender língua majoritária não existisse, talvez os mais velhos que não deixam as comunidades falantes de dialetos aprendessem dos mais jovens a língua majoritária que esses aprendem na escola - algo que não parece ocorrer de modo geral, também de acordo com os dados coletados.

Os quadros a seguir ilustram as hierarquias de preferências do ponto de vista de cada um dos participantes, "periferia", "elite regional" e "poder central", respectivamente, Nestes quadros entende-se:

- L1 como sendo o dialeto / língua materna

- L2 como sendo a segunda língua, que no caso do falante de dialeto, é o português.

- L3 como sendo a variante padrão correspondente ao dialeto.

- L4 como sendo qualquer outra língua estrangeira, não coincidente com a variante padrão que corresponde ao dialeto. Para efeito desse jogo, L4 é a língua inglesa, por ser o ensino dessa língua obrigatório em todo o território nacional.

Embora a existência de falantes perfeitamente bilíngües em português seja um fato concreto, esse fato não exclui a existência de falantes de dialeto que não sabem português e para os quais o português representa uma segunda língua. Os quadros a seguir são, portanto, construídos de forma a contemplar as preferências desses últimos falantes e, em termos simplificados, representam o escalonamento de preferências em função de menor esforço - o que resulta, a priori, em um empate nas células onde a L1 tenha de competir com L3 e L4.

1- Jogo entre o falante de dialeto com o poder central:

\begin{tabular}{|c|c|c|c|c|c|}
\hline & L1 & L1+L2 & L1+L2+L3 & L1+L2+L4 & L1+L2+L3+L4 \\
\hline $\begin{array}{c}\text { Preferências do } \\
\text { falante de } \\
\text { dialeto }\end{array}$ & 4 & 3 & 2 & 2 & 1 \\
\hline
\end{tabular}


Na hierarquia das preferências descritas, no quadro acima, portanto, a preferência de peso 4 representa o desejo dos falantes pela manutenção de sua língua materna, isenta do esforço de aquisição de qualquer outra língua. A preferência de peso 3 representa o desejo do falante da língua minoritária de aprender a língua do poder central. No nosso contexto, para o falante de línguas imigrantes, a segunda língua que oferece o maior prêmio é, sem dúvida, o português, e não faria sentido para o falante da língua minoritária aprender qualquer outro idioma antes do português. A preferência de peso 2 representa o esforço de aprendizado de uma terceira língua. A escolha dessa terceira língua sendo ditada pelo prêmio associado a essa terceira língua. No caso da competição entre duas línguas, uma sendo a variante padrão correspondente ao dialeto e a outra uma língua estrangeira, supondo-se que haja competição por recursos, a preferência do falante será pela língua que oferecer maiores vantagens.

Ou seja, na ausência de influências externas, a preferência do falante seria de permanecer utilizando sua língua materna. Esse cenário não sendo possível, aí sim o falante de língua imigrante fará um movimento na direção da aquisição de uma segunda língua e de uma terceira língua. É importante frisar que o esforço pelo aprendizado de uma língua além da língua materna só ocorrerá diante da possibilidade de um retorno pelo investimento do seu esforço. Ainda que diante da obrigatoriedade imposta por um sistema educacional, temos de compreender que tal obrigatoriedade está associada à promessa de prêmios para quem cumpre o requisito.

2 - Jogo entre a elite regional e o poder central:

\begin{tabular}{|c|c|c|c|c|c|}
\hline & L1 & L1+L2 & L1+L2+L3 & L1+L2+L4 & L1+L2+L3+L4 \\
\hline $\begin{array}{c}\text { Preferências da } \\
\text { elite regional }\end{array}$ & 1 & 2 & 4 & 2 & 3 \\
\hline
\end{tabular}

$\mathrm{Na}$ hierarquia das preferências descrita no quadro acima, portanto, a preferência de peso 4 representa o desejo da elite regional pela promoção de sua variante padrão livre da competição com uma outra língua estrangeira, pois, dessa forma, o seu investimento na promoção da variante padrão não corre o risco de não ter retorno, já que a valorização da variante padrão está associada à valorização da região. A elite regional perde com a evasão de cada dissidente de uma forma semelhante à de uma empresa que treina um funcionário que acaba indo trabalhar para um concorrente. Entretanto, já que o poder central impõe o ensino 
da língua inglesa na posição de L4, a elite regional tem que lidar com a competição entre L3 e L4. A preferência de peso 3 ilustra essa competição, já que agrega para a elite regional o possível retorno do investimento em L3, embora também acarrete um risco de dissidência. $\mathrm{Na}$ verdade talvez o maior retorno para o investimento desse falante de L3 e L4 exista fora da região, já que se permanecer lá estará competindo com outros falantes de L3 e L4, não tendo sobre eles as vantagens que teria em outras regiões onde o seu recurso represente maior grau de diferencial.

As preferências de peso 2 representadas no quadro acima não incluem o reconhecimento da variante padrão promovida pela elite regional no seu esforço de busca por afirmação. A ausência de L3 pode ser um fator mais determinante de evasão da região do que a presença de L4, já que a oferta de L4 é universal no nosso contexto. Na medida em que os esforços pela promoção de L3 sejam bem sucedidos, esses esforços podem converter-se em exigências no mercado de trabalho, que se não atendidas pelo indivíduo que não tenha aprendido L3 podem levar à evasão do indivíduo para outras regiões onde tal exigência não exista, criando-se efetivamente um sistema de exclusão.

A preferência de peso 1 no quadro acima representa um quadro de exclusão, já que o falante não participa de nenhum contexto externo a sua comunidade, não representando nenhum recurso para a elite regional no seu esforço de afirmação.

3- Jogo entre o poder central e a periferia:

\begin{tabular}{|c|c|c|c|c|c|}
\hline & L1 & L1+L2 & L1+L2+L3 & L1+L2+L4 & L1+L2+L3+L4 \\
\hline $\begin{array}{c}\text { Preferências do } \\
\text { poder central }\end{array}$ & 1 & 2 & 2 & 4 & 3 \\
\hline
\end{tabular}

Na hierarquia das preferências descrita no quadro acima, portanto, a preferência de peso 4 representa a posição que requer por parte do poder central o menor dispêndio de recursos, já que não se fazem necessárias alterações na estrutura do sistema. Some-se a isso o fato de que L4 é interessante para o poder central no seu jogo de inserção no contexto globalizado. A preferência de peso 3 acarreta o investimento decorrente da adaptação da estrutura do sistema para a inclusão de L3 sem que se possa garantir o retorno do investimento em L3 que agora entra em competição com L4 no nível dos recursos a serem investidos pelo aprendiz. Ainda que recursos de ordem financeira não fossem problema, 
teríamos de confrontar a realidade das limitações impostas por tempo e carga horária a serem destinados. Se a oferta de L3 for facultativa, o investimento do poder central na criação da estrutura necessária poderá não ser correspondido. Se a oferta de L3 for obrigatória, estará em disputa pela alocação de recursos do aprendiz, que também comprometem o possível retorno para o poder central.

Poder-se-ia alegar as possíveis vantagens de aprenderem-se duas línguas, ainda que precariamente, entretanto tal situação pode não ser ótima para o poder central, para quem L4 é indiscutivelmente útil diante do seu esforço de inserção no mundo globalizado. A preferência de peso 2 reflete a ausência de L4, que prejudica o poder central no seu esforço de inserção com relação ao "poder central" acima dele, representado pela supra-estrutura globalizada. Em suma o poder central no nível da nação deseja afirmar-se diante da supra-estrutura globalizada da mesma forma que a elite regional busca afirmação diante do poder central no plano da nação.

A preferência de peso 1 novamente remete a um isolamento que não é útil para o poder central no seu esforço de afirmação diante da supra-estrutura globalizada além de dificultar o processo de racionalização do estado.

Diante dos quadros acima, ficam visíveis as diferentes preferências de cada jogador. A análise dos quadros demonstra a complexidade da questão e a dificuldade de conciliação de interesses, além de apontar para um impasse entre a diversidade da realidade e a necessidade de generalização inerente à políticas públicas.

\subsection{Mais opções ou melhores escolhas?}

Até aqui nossas considerações giraram em torno das relações entre uma periferia dividida e um poder central racionalizador de uma identidade nacional. O momento presente, contudo, nos apresenta um cenário ainda mais complexo. Não poderíamos deixar de analisar o fato de que a dinâmica dessas relações está agora sujeita a novas forças e pressões externas, algumas encampadas pelo poder central em seu próprio esforço de movimentação e outras cuja dimensão e impacto ainda nos são desconhecidas. Tais forças impostas pelo fenômeno da globalização acarretam novas preocupações, novos anseios e novos alinhamentos que, por sua vez, geram um novo nível de jogo.

O economista John Kenneth Galbraith (1996), ainda na década de 1980, anunciava o que chamara de a "era da incerteza". Diante do processo de globalização, existem as possibilidades de adesão e de resistência, sem que possamos ter certeza de qual 
posicionamento oferecerá os maiores benefícios. Embora a globalização pareça um processo irreversível, talvez ainda seja cedo para avaliarmos quais os melhores mecanismos para a inserção nesse processo. Trazendo o problema para o nosso cenário, ainda pode ser cedo para sabermos se o inglês será mais útil do que o alemão ou vice-versa. Diante do fato de que a Comunidade Européia elegeu a língua inglesa como sua língua oficial ao invés do alemão, "que era a outra possibilidade" (Fishman 2006, p. 36), existem condições para um processo de assimilação competitiva, semelhante ao proposto por Laitin (1988), em que a língua inglesa competirá com a língua alemã onde o ensino de ambas seja viável.

Diante dessa realidade, não podemos descontar a possibilidade de que membros da elite regional, ao perceberem o abandono da herança imigrante, diante das perdas testemunhadas, sobretudo nas áreas urbanas, pudessem interpretar tal abandono como uma "corrida por fora", rumo a uma modernidade inevitável e a assimilação completa de grupos até então não reconhecidos. Diante de maiores possibilidades de afirmação, a elite regional reconhece o potencial de sua periferia que pode agregar números a um esforço por hegemonia regional e auxiliar a manutenção do status dessa elite regional por oferecer ao poder central um recurso, representado pela variante padrão de uma língua européia, escasso em outras regiões.

Como reconciliar então esta movimentação na direção do novo, ocasionalmente expresso até no desejo dos jovens pelo abandono da língua imigrante, com o apego à variante padrão por parte da elite regional?

Considerando-se que as elites regionais tendem a ser urbanas e que é justamente nas áreas urbanas que ocorrem as maiores perdas decorrentes de language shift, exatamente por conta da eficiência seletiva inerente ao processo de assimilação competitiva, parece curioso que o apego pela variante padrão seja proveniente justamente dessas áreas. É possível que o desejo de assimilação das elites permaneça existindo em um mundo onde o seu recurso diferencial, até então ignorado, tenha recobrado algum valor e esta percepção de potencial utilidade à manutenção do status do grupo esteja por trás dos esforços de revitalização de língua imigrante. 


\section{CAPÍTUlo 9 - CONCLUSÕES}

\subsection{Especificidades locais e consciência da diversidade}

É justamente na preservação das especificidades locais que encontramos a dimensão ética do legislar sobre a língua de comunidades que ainda utilizem dialetos, como no caso de Angelina. Antes de podermos legislar, é importante que tenhamos compreensão de alguns aspectos fundamentais. O primeiro deles é determinar se os falantes têm consciência de falarem um dialeto. Isso pode parecer desnecessário ou mesmo estranho a princípio, mas a realidade é que os falantes podem desconhecer a existência de diferenças significativas entre a variante dita padrão e a variante por eles utilizada.

No caso de nossos quatro entrevistados, nenhum deles sabia em que o alemão da região de Angelina difere da variante padrão, mas todos concordaram ser a sua variante "diferente", mesmo apesar do fato de que apenas dois dos entrevistados falarem dialeto, sendo os outros dois descendentes de alemães que falam apenas português. Percebe-se a partir disso que a comunidade de Angelina possui uma consciência lingüística sobre a diferença da língua local e talvez seja apenas o reconhecimento dessa diferença o fator de união entre os Angelinenses depositários do dialeto e os que optaram, em algum momento de suas trajetórias, por abandonar a língua imigrante.

Acreditamos que somente quando cientes da existência da diferença e daquilo que tal diferença implica para a própria língua e para a comunidade é que poderão os depositários de dialetos fazer uma escolha informada sobre estudarem a variante padrão de suas línguas e o mesmo poderia ser dito sobre os legisladores proponentes da variante padrão diante da realidade de que não há ainda levantamentos específicos sobre a situação dos dialetos.

A simples imposição de uma variante padrão pode desencadear disputas com relação ao suposto maior prestígio da norma padrão e um desdém para com os dialetos locais e para com seus falantes por parte de ramos dessas comunidades. Tais divisões podem ocorrer, e, com certa frequiência, ocorrem, dentro das próprias famílias onde a trajetória de um membro específico possa tê-lo afastado do dialeto em troca da variante padrão.

O potencial para tensões e discriminação não é difícil de enxergar em nossa comunidade de estudo, onde várias pessoas ouvidas falaram das vezes em que os mais velhos descem à cidade trazendo os mais jovens como intérpretes. 
Em suma, nosso entendimento é de que a língua estrangeira, em sua variante padrão, em casos em que possa haver sobreposição sobre os dialetos, pode ser ensinada desde que não seja apresentada a essas comunidades de forma que possa ser confundida com a língua imigrante. As decisões sobre tais políticas devendo ficar a cargo das comunidades lingüísticas envolvidas. O professor de alemão Altair Luis Bender, referindo-se à situação do dialeto de Venâncio Aires no Rio Grande do Sul, alerta para essa realidade.

Temos de valorizar a língua do interior, porque esse alemão é o primeiro idioma que as crianças aprendem. Elas têm de saber que não estão falando errado relata Bender. (BRUM, 2005)

Ignorar a realidade de vantagens e desvantagens associadas a cada língua oferecida pode, por questões de uma aparente proximidade lingüística, afastar os alunos dessas comunidades de outras opções de língua estrangeira, quando essas existirem. Para falantes de dialeto, pode ser mais fácil aprender a variante padrão correspondente, ainda que precariamente, do que aprender uma outra língua, como o inglês, por exemplo. Se considerarmos que o aprendizado de línguas estrangeiras envolve uma competição pelos recursos do aluno, o mesmo poderá direcionar seus esforços para aprender a língua que lhe parece mais fácil. Cada esforço deve ter seu espaço de forma que não comprometa um outro, para que possamos ter êxito em nossas iniciativas, promovendo a verdadeira diversidade lingüística e a formação educacional.

Como afirma Giordano (2005, p.16), “a escolha do código linguístico acaba por representar assuntos políticos, econômicos e culturais" e, por conta dessa complexidade em diversos planos, merece a atenção das comunidades e legisladores.

\subsection{A ecologia do sistema}

Parece-nos que quaisquer iniciativas, que podem ser, por falta de compreensão de sua especificidade, complexidade e aplicabilidade, potencialmente nocivas por interferirem em determinados contextos lingüísticos sem que tenham sido contempladas as implicações e desdobramentos que afetam o sistema lingüístico de forma análoga a de um ecossistema. A introdução de uma variante em um sistema lingüístico, dessa forma, assemelha-se à introdução de uma nova espécie de animal sem que tivéssemos o cuidado de saber se será capaz de coexistir com as demais espécies, sem tornar-se presa ou predador.

For his part, Haugen defines language ecology as "the study of interactions between any given language and its environment," going on to define the environment of the language as including both psychological ("its interaction with 
other languages in the minds of bi- and multilingual speakers") and sociological ("its interactions with the society in which it functions as a medium o communication"). Van Lier (2000) cites Trim (1959) as the first reference to ecology of language aspects. (HAUGEN apud HORNBERGER, 2002, p. 33)

A resposta para o impasse de como reconciliar as línguas imigrantes com as necessidades do mundo globalizado pós-moderno se encontraria, de acordo com Hornberger (2002, p. 47), nas propostas recentes para solidificar, apoiar e promover as línguas imigrantes. Ainda segundo Hornberger (2002, p. 47), nos Estados Unidos, por exemplo, tais propostas contam com o suporte de entidades dedicadas a melhor compreensão da questão, como o Center for Applied Linguistics e o National Foreign Language Center.

Se a variante padrão estiver sendo oferecida para solidificar a língua imigrante, é importante que pensemos sobre o esforço na direção de solidificar algo que, no caso dos dialetos imigrantes, possivelmente tenha mais solidez do que a variante padrão que se pretende oferecer.

É importante ainda perceber-se que países com longa tradição de valorização de línguas imigrantes como recursos optaram por uma nomenclatura clara e específica com relação à essas línguas com o intuito de distingui-las de simples línguas estrangeiras. Tal distinção pode parecer irrelevante a princípio, mas é crucial para a implementação de estratégias de ensino adequadas a cada modalidade.

Happily, however, there is also a move afoot in recent years among U.S. linguists and language educators to help solidify, support, and promote longstanding grassroots minority language maintenance and revitalization efforts in the United States, under the rubric of "heritage languages." The Heritage Language Initiative, which has among its priorities "to help the U.S. education system recognize and develop the heritage language resources of the country" and "to increase dialogue and promote collaboration among a broad range of stakeholders" (CAL apud HORNBERGUER, 2002)

Se os próprios proponentes de abordagens ecológicas, contudo, admitem a hipótese de que se valorize e incentive as línguas imigrantes, onde se encontra o problema com as iniciativas que neste momento contemplam localidades como Butiá, Pomerode, Venâncio Aires e Blumenau? A resposta é muito simples. Existe uma diferença muito grande entre a oferta de uma "língua imigrante", no verdadeiro sentido da palavra, e a oferta de algo que seja apenas parecido com ela. Se todos os membros dessas comunidades fossem depositários da variante padrão e não houvesse membros de etnias não contempladas por medidas semelhantes nas escolas, talvez pudéssemos olhar para a implementação de tais políticas com mais tranqüilidade. Porém, a realidade é heterogênea e as preferências difíceis de serem reconciliadas, conforme demonstramos no capítulo 4. 
Mesmo no caso dos Estados Unidos houve cautela com relação ao tratamento da língua imigrante nos bancos escolares e seu tratamento foi freqüentemente removido do espaço das salas de aula.

Uma língua que seja oferecida à comunidade por sua semelhança com um dialeto local, sem que a própria comunidade possua, em muitos casos, uma consciência a respeito da existência dessa diferença, e que seja oferecida atrelada a uma condição de prestígio superior, não é difícil perceber, vem carregada da possibilidade de gerar conflitos e tensões dentro do ecossistema.

Isso não sendo suficiente, essa nova e, talvez, mais poderosa versão da língua falada em casa é promovida como alternativa para o ensino do inglês que, embora sendo língua obrigatória, agora terá de dividir a atenção de um aluno possivelmente tentado a estudar algo que, por semelhança, lhe pareça mais fácil dentro de um sistema educacional, em geral, já deficitário de toda sorte de recursos. É difícil refutar a competição por recursos, tanto do ponto de vista do aluno como por parte do sistema educacional - sendo a competição por recursos um aspecto econômico introduzido nessa discussão com base tanto em conceitos de Laitin (1988 e 1993) quanto em conceitos apresentados por Grin e Vaillancourt (1997).

Existe, por isso uma diferença muito grande entre a oferta de línguas imigrantes e a oferta de variantes cultas correspondentes a línguas imigrantes e as implicações não são difíceis de imaginar. Quando uma criança falante de português, pertencente a uma comunidade falante de português, vai para a escola e aprende uma língua estrangeira qualquer, ela traz para sua casa, quando muito, algumas frases que podem gerar certa curiosidade e com alguma sorte o desejo, até possível de ser partilhado pelos demais familiares, de aprender mais desse novo idioma. Além disso, parece lógico que, no caso dos falantes de dialeto, foi um dialeto que trouxeram e quaisquer políticas que visem contemplar esta questão deveriam fazê-lo com a coerência de um tratamento consistentemente distinto, sem confundir os dialetos imigrantes com línguas estrangeiras modernas.

Quando uma criança que fala dialeto traz para a casa a variante culta desse dialeto, ela passa a fazer parte, ainda que de forma não intencional, de um embate de forças e de um jogo de interesses. De uma hora para a outra, o dialeto que ali sempre foi falado já pode não parecer mais suficientemente bom; tal preço poderá ser pago, sem que sequer tenhamos dados sobre a possibilidade real de um language shift bem sucedido, permanecendo o risco da desestabilização lingüística da comunidade pela introdução de um elemento de interferência em um ecossistema até então bem sucedido com relação à sobrevivência da língua e que pode 
potencialmente converter-se em palco para o desencadeamento de tensões que eram até então inexistentes.

\subsection{Um mundo de prêmios, riscos e preços}

Lembramos que o intuito deste trabalho não é o de levantamentos estatísticos. Queríamos que a pesquisa servisse, sobretudo, como instrumento de reflexão, ouvindo pessoas e demonstrando que mesmo diante de grupos muito pequenos, estaremos freqüentemente diante de opiniões divergentes no que diz respeito à manutenção de seu patrimônio e de seu futuro lingüístico.

Partindo-se do pressuposto de que a existência de um dialeto reflete uma escolha coletiva de uma comunidade, é necessário levar em consideração diversos fatores, tais como: a viabilidade de ensino contraposta à viabilidade de aprendizagem; a interferência imposta ao sistema pelas questões de prestígio trazidas para dentro do sistema; o desvio com relação a um objetivo educacional possivelmente maior; o interesse por traz do fomento de um language shift; o desejo pela modernidade representada pelo abandono da língua dos mais velhos; a realidade de um mundo globalizado e novas imposições lingüísticas; a dimensão da escolha individual; o papel da língua na construção das identidades individuais e coletivas; a "ecologia" de sistemas lingüísticos; e os mecanismos de sobrevivência dos artefatos humanos. Não observar tais fatores pode impor uma série de mudanças cujos custos não tenham sido determinados.

Language policies in multilingual societies are beset by the trade-off between standardization and disenfranchisement. Linguistic standardization comprises any set of policies that promote the dominant use of a unique or several languages while limiting the usage of other languages spoken by the population at large. Indeed, linguistic standardization may deliver important benefits in terms of greater ease of communication, reducing costs of translation, increased trade, improved economic performance and administrative efficiency. However, excessive standardization may exacerbate the alienation of large minorities and widen the existing chasm between linguistic communities (LAPONCE apud GINSBURG; WEBER, 2006, p. 1-2)

\subsection{Considerações Finais}

Por conta dos deslocamentos de centro e periferia, parecemos destinados a jogar vários jogos simultaneamente.

Diante da força e da pressão de centros distintos, localidades como Blumenau já se encaminharam para a obrigatoriedade da língua alemã, em paralelo à língua inglesa, como já 
vimos, nas escolas públicas do município. Ainda que descontássemos a existência dos falantes de dialetos lá existentes, já teríamos de nos perguntar se tais medidas são pelo menos justas.

Em princípio, um olhar focalizado estritamente nas questões relevantes para o grupo minoritário pode tornar difícil a percepção de possíveis problemas em nossas propostas de inclusão. Não devemos esquecer que o domínio das políticas públicas é o da promoção da sociedade como um todo e essa constatação nos força a refletir sobre o impacto que políticas destinadas a um grupo específico possam ter sobre o seu entorno.

Se tais esforços forem bem sucedidos em gerar falantes de duas línguas francas para um mundo globalizado, isso seria extremamente benéfico para a região, mas possivelmente injusto para com todos os outros estudantes do resto do país sem acesso a duas línguas estrangeiras na escola pública. Essa hipótese de sucesso convive, todavia, com a realidade inexorável da competição por recursos e, na prática, talvez seja, pouco promissora. Talvez entre esses dois pólos oscile o custo maior do que o benefício, sobre o qual nos alertam Grin e Vaillancourt (1997).

Talvez o custo mais iminente seja o acarretado pela possível naturalização de mais uma exigência educacional que pode vir a ter manifestação na esfera do mercado de trabalho sob a forma de mais um obstáculo para o acesso a determinados empregos. Na medida em que a sociedade e o mercado de trabalho possam perceber o domínio de uma nova língua como uma obrigatoriedade dentro do sistema educacional, poderemos nos deparar com um mercado de trabalho que acredite ter o direito de exigir essa língua. Estaríamos dessa forma diante de um processo de naturalização que, embora não necessariamente contrário à intenção original de ampliar espaços no mercado de trabalho, poderia complicar ainda mais a questão do acesso às vagas desse mercado.

A atual percepção de que o ensino da variante padrão é importante para o acesso ao mercado de trabalho está contraposta à percepção, por parte desse mesmo mercado, sobre a disponibilidade dessa mão de obra. Na medida em que o mercado de trabalho perceba o domínio dessa segunda língua como "natural", o seu valor enquanto vantagem tenderá a desaparecer para os falantes da mesma, ao mesmo tempo em que a desvantagem permanecerá para os que não aprenderem essa língua. Em termos práticos, as vantagens para o falante podem ficar reduzidas ao nível da vantagem sobre o concorrente que não fala a língua, deixando de representar vantagem profissional em termos de carreira ou salários, como já é o caso com o idioma inglês, sobretudo nas grandes capitais brasileiras, onde o mesmo já é percebido, por muitas empresas, tão somente como uma obrigação para o acesso ao emprego e não como um diferencial. Isso poderia parecer bom e simples decorrência de um processo 
de naturalização, mas a realidade brasileira é que nem todos, independentemente até da qualidade da escolaridade recebida, falam inglês.

Ironicamente, podemos estar diante de um mundo onde o preço da diversidade é a própria diversidade; onde pagamos por algo não reivindicado com a perda de algo que nos é caro. Neste mundo pós-moderno a maior oferta de opções pode parecer tentadora; mas quando o peso das opções não é conhecido, a escolha pode apenas ter-se tornado mais difícil por conta das novas opções.

Se considerarmos a simples liberdade das escolhas e a possibilidade, ainda que nos pareça infundada, de que o falante de dialeto pode desejar, em algum ponto de sua trajetória, o simples abandono do mesmo, estaremos diante do fato de que ele poderá não eleger a variante padrão para substituir sua língua imigrante que, de acordo com os teóricos, tende naturalmente ao desaparecimento.

O desejo por parte de uma elite de "lealistas protetores", nos termos de Laitin (1988), da variante padrão pode não encontrar eco na periferia de falantes de dialeto. Na verdade, pode ser que esses proponentes da variante padrão, caso estejam diante de uma estratégia de assimilação competitiva, por parte da periferia de falantes de dialeto, sejam os primeiros deixados para trás na corrida para atender as demandas da nova supra-estrutura globalizada. A elite regional estaria efetivamente presa a um passado que a periferia já teria decidido abandonar.

A questão que buscamos abordar é complexa e não parece haver respostas conclusivas. Na falta de tais respostas, somos deixados sempre diante do dilema da escolha. Quando não sabemos qual opção é a melhor, talvez o melhor curso de ação seja o de não fazer escolha alguma. Essa possibilidade nos parece ainda mais atraente diante da realidade de tratarem-se as escolhas pertinentes à língua imigrante de escolhas que habitam o plano individual e para as quais um consenso nos parece difícil diante dos dados.

A periferia nunca se moverá uniformemente, expandindo-se na medida em que sua vanguarda avança na direção do centro, deixando para trás os mais relutantes, ou aqueles que já não podem prosseguir em sua marcha. Indo rumo ao centro, a periferia deixa para trás uma nova periferia de excluídos, por conta do que não fora contemplado de antemão.

Talvez possa-se argumentar que agora os excluídos são em menor número, porém, devido à própria natureza da exclusão, poderemos estar quase certos de se tratarem esses indivíduos dos que mais necessitavam de auxilio para a sua inclusão.

No mesmo mundo pós-moderno de incertezas, todavia, a realidade dessa conclusão também tem de ser questionada e tal questionamento remeterá, mais uma vez, ao eixo centro- 
periferia que se projeta sobre a realidade sociolingüística em questão. Romper com essa projeção significa retomar a noção de que nossos mapas não representam o território. Talvez o verdadeiro eixo tenha de ser estabelecido em função do sucesso de preservação do patrimônio lingüístico em uma nova hierarquia, onde o centro permaneceria em sua função central decorrente do poder político e da delimitação territorial, mas onde a elite regional seja a elite de falantes de dialeto em um mundo lingüístico mais forte do que o mundo lingüístico urbano, cujos esforços pelo incentivo da língua podem representar uma posição periférica e mais fraca.

Como afirma Wight (1999, p.122), “o que Derrida estava tentando dizer é que o centro é ele próprio um efeito da estrutura ao invés de ser um ponto de origem ou natural”.

Dessa forma, talvez as medidas atuais de promoção representem exatamente um esforço e uma escolha, por parte dos falantes da variante padrão, pela sua própria sobrevivência, diante da realidade de que alguns falantes de dialetos, de fato, serão convertidos em falantes da variante padrão ao mesmo tempo em que os dialetos têm poucas chances de desaparecer em decorrência de interferências externas.

Talvez línguas que não precisaram de ajuda para sobreviver por mais de 150 anos continuem não precisando e devemos considerar a hipótese de que talvez a mesma força por trás desse patrimônio preservado seja ainda capaz de mantê-lo vivo ou mesmo protegê-lo de influências externas.

A resposta para a pergunta inicial de pesquisa sobre ser a sobreposição da variante padrão um incentivo ou uma ameaça não pode ser resolvida de modo simples. A realidade da sobreposição é que representa uma interferência sem que entremos no mérito do termo, que é aqui utilizado com neutralidade. Se a natureza dessa interferência será positiva ou negativa dependerá do paradigma de avaliação projetado sobre a situação e dos objetivos propostos pelas iniciativas que venham a ser implementadas. 


\section{REFERÊNCIAS}

ALTENHOFEN et ali. "Fundamentos para uma escrita do Hunsrückisch falado no Brasil." In: Revista Contingentia. Porto Alegre, No. 2. pp.73-87. 2003.

BAGNO, Marcos. A norma oculta: língua \& poder na sociedade brasileira. São Paulo, Parábola, 2003

BLUMENAU. Lei Complementar No 487 - Conselho Municipal da Língua Alemã. 2004.

BRUM, Marciele. “Alemão falado no interior ganha dicionário”. In: Zero Hora. Porto Alegre, p. 40. 18/02/2005.

CALVET, Louis-Jean. Sociolinguiística: uma introdução crítica. São Paulo, Parábola, 2002.

CHAMBERS, J. K. Sociolinguistic theory: linguistic variation and its social significance. Blackwell Publishing. Malden. 2002.

CONSELHO NACIONAL DE EDUCAÇÃO. Parecer no. CEB 04/98. 1998. Disponível em: <http://portal.mec.gov.br/cne/arquivos/pdf/PCB04_1998.pdf>

Acesso em 17/12/08

CURY, Daniel. "A construção da identidade do aluno migrante em sala de aula" In: Língua, literatura e ensino. Vol. 3. 2008. pp. 127-132. Disponível em: <http://www.iel.unicamp.br/revista/index.php/lle/article/viewFile/92/76.> Acesso em: 09/12/2008

CUMMINS, J. "Bilingual children's mother tongue: why is it important for education." I teach I learn.com: educational ideas and solutions. Disponível em < http://www.iteachilearn.com/cummins/mother.htm>.

Acesso em: 17/12/2008

DANIEL, Isaura. “A língua dos avós no currículo escolar". In: Zero Hora. Porto Alegre, p. 48. $25 / 06 / 2000$.

EDUHAUS et ali. "Oktoberfest numa pequena cidade gaúcha”. Disponível em: <http://www.skyscrapercity.com/showthread.php?t=275148>. Acesso em: 26/08/2008.

DERRIDA, Jacques. "Structure, sign and play in the discourse of the human sciences". In: NATOLY, Joseph; HUTCHEON, Linda. (orgs.) A postmodern reader. SUNY Press. 1993.

FÁVERI, Marlene de. Memórias de uma (outra) guerra: cotidiano e medo durante a segunda guerra em Santa Catarina. Univali. 2005.

FISHMAN, Joshua A. "300-plus years of heritage language education in the United States". In: PEYTON, Joy. (org) Heritage languages in America: preserving a national resource. Center for Applied Linguistics and Delta System. 2001.

GALBRAITH, J.K. A era da incerteza. Thomson Pioneira. São Paulo. 1996.

GAMBHIR, Surendra. "Truly less commonly taught languages and heritage language learners in the United States". In: Peyton, Joy. (ed) Heritage languages in America: preserving a national resource. Center for Applied Linguistics and Delta System. 2001. 
GIORDANO, Eliane Cristine. Parâmetros curriculares nacionais de língua estrangeira moderna (PCN-LE): o inglês como componente curricular dos terceiros e quartos ciclos do ensino fundamental. Mestrado em Educação: História, Política, Sociedade. PUC/SP. 2001

GOFFMAN, Erving. A representação do eu na vida cotidiana. Vozes. Petrópolis. 2007

GRIN, François; VAILLANCOURT, Francois. "The economics of multilingualism: overview and analytical framework". In: Annual Review Of Applied Linguistics. Cambridge, Ma, Vol. 97, No. 0267-1905, pp. 43-65, 1997.

GRIN, Fraçois. "Economic considerations in language policy". In: RICENTO, Thomas. (org). An introduction to language policy: theory and method. Blackwell Publishing. Malden.2006

HORNBERGER, Nancy H. "Multilingual language policies and the continua of biliteracy: an ecological approach”. In: Language Policy. Vol. 1 No. 1. pp. 27-52. Mar. 2002. Springer Netherlands

"English in the global ecology of languages: the value of

multilingualism”. In: Besig Business Issues. Rotterdam. No 2. pp. 2-6. 2003.

KAUFMANN, Goez. Language maintenance and reversing language shift. 2005

KLOSS, Heinz. American Bilingual Tradition. CAL. 1997.

KOCH, W; KLASSMAN, M.S.; ALTENHOFEN, C. V. Atlas linguístico-etnográfico da região sul do Brasil. UFRGS, UFSC e UFPR. 2002

LAITIN, David. “Language games”. In: Comparative Politics. Vol. 20 No. 3. pp. 289-302. apr. 1988.

"The game theory of language regimes". In: International Political

Science Review/Revue Internationale de Science Politique. Vol. 14 No. 3. pp. 227 239. jul. 1993.

MEIHY, José Carlos Sebe Bom. Manual de história oral. Edições Loyola. São Paulo. 2005.

MOSER, Anita. A Violência do Estado Novo Brasileiro contra italianos. 2004.

Disponível em: <http://www.ipol.org.br/imprimir.php?cod=200>

Acesso: 16/12/2008

MIRANDA, Sandro Ari Andrade. A Inconstitucionalidade do Art. 335 do Código Eleitoral Brasileiro. < http://jus2.uol.com.br/doutrina/texto.asp?id=7418>

Acesso em: 10/12/2008

NATOLI, Joseph; HUTCHEON, Linda. "Representing the post-modern" In: A Post-modern reader. SUNY Press. New York. 1993.

OLIVEIRA, Gilvan. “Aprovado projeto Plures do IPOL em Blumenau/SC”. Disponível em: $<$ http://www.ipol.org.br/imprimir.php?cod=109>.

Acesso em: 15/ 08/ 2008.

PORTAL GALEGO DA LÍNGUA. "Comparsas em defesa da língua".

$<$ http://www.pglingua.org/index.php?option=com_content $\&$ view=article\&id=671: compa rsas-em-defesa-da-lingua \&catid=8:cronicas $\&$ Itemid=69> .

Acesso em: 02/05/2009 
PEYTON, Joy. (ed) Heritage languages in America: preserving a national resource. Center for Applied Linguistics and Delta System. 2001.

RICENTO, Thomas (org.). An introduction to language policy: theory and method. Blackwell Publishing. Malden. 2006.

SANTA CATARINA. Sem Título. Disponível em: <http://www.sc.gov.br/portalturismo/Default.asp?CodMunicipio=230\&Pag=1> Acesso em: 18/12/2008

SCHMIDT, Sr., Ronald. "Political theory and language policy". In: RICENTO, Thomas. (org.). Language policy: theory and method. Blackwell Publishing Ltd. 2006.

STEFFEN, Joachim. "A vantagem de falar de dialeto: aproveitar as variedades não-padrão para a construção de comunidades multilíngües." In: Revista Contingentia. Vol. 3 No. 2. 2008. http://www.seer.ufrgs.br/index.php/contingentia/article/viewArticle/6969/4298 Acesso em: 20/12/2008

TEIXEIRA, Jerônimo. "Riqueza da Língua”. In: VEJA. São Paulo. Editora Abril. Edição 2025.Vol. 40. No. 36. pp. 88-89. 12/09/2007.

TOLLEFSON, James. Planning language, planning inequality. Longman. London. 1991.

TRESSMAN, ISMAEL. “A co-oficialização da língua pomerana.” Faculdade da Região Serrana. < http://www.farese.edu.br/artigos/Cooficialização\%20da\%20L\%20Pomer.pdf> Acesso em: 15/12/2008

U.S. DEPARTMENT OF EDUCATION. Education in the United States: a brief overview. 2003

VILELA, Soraia. “O alemão lusitano do sul do Brasil.” DW-World. 2004. < http://www.goethe-bytes.de/dw/article/0,,1174391,00.html> Acesso em: 22/12/2008.

WILEY, Terence. "The Lessons of Historical Investigation: Implications for the Study of language Policy and Planning”. In: RICENTO, Thomas. (org.). Language policy: theory and method. Blackwell Publishing Ltd. 2006.

WIGHT, Colin. “They shoot dead horses. Don't They? Locating Agency in the AgentStructure Problematique" In: European Journal of International Relations. Vol. 5. No. 1. pp. 109-142. 1999.

ZERO HORA. "Língua alemã conquista espaço nas salas de aula". In: Zero Hora. Porto Alegre, p. 40. 06/04/2005. 
ANEXOS 


\section{Anexo A - Autorizações para utilização de entrevistas}

\section{AUTORIZAÇÃO PARA UTILIZAÇÃO DE ENTREVISTA}

$\mathrm{Eu}$, portador(a) do RG no. abaixo assinado(a), por meio deste instrumento, declaro para os devidos fins que cedo os direitos de minha entrevista, gravada no município de Angelina, Santa Catarina, em de julho de 2007, como subsídio para a dissertação de mestrado de Jordan Hahn Bandeira pela Universidade de São Paulo - USP, ficando autorizada a sua utilização em forma e conteúdo, em todos os seus possíveis formatos de veiculação, tais como gravações de áudio digital e/ou analógico, transcrições totais e/ou parciais, bem como as transcriações da entrevista gravada, sem restrições de prazos e limites de citações, desde a presente data, desde que respeitadas as restrições especificadas abaixo. Da mesma forma, autorizo a terceiros o acesso ao material e possíveis citações, ficando vinculado o controle à Universidade de São Paulo - USP.

Abdicando de direitos meus e de meus descendentes, subscrevo a presente, que terá minha firma reconhecida em cartório.

\section{RESTRIÇÕES:}

\section{Assinatura}

Nome:

Local e Data 
Anexo B - Artigos do Jornal Zero Hora

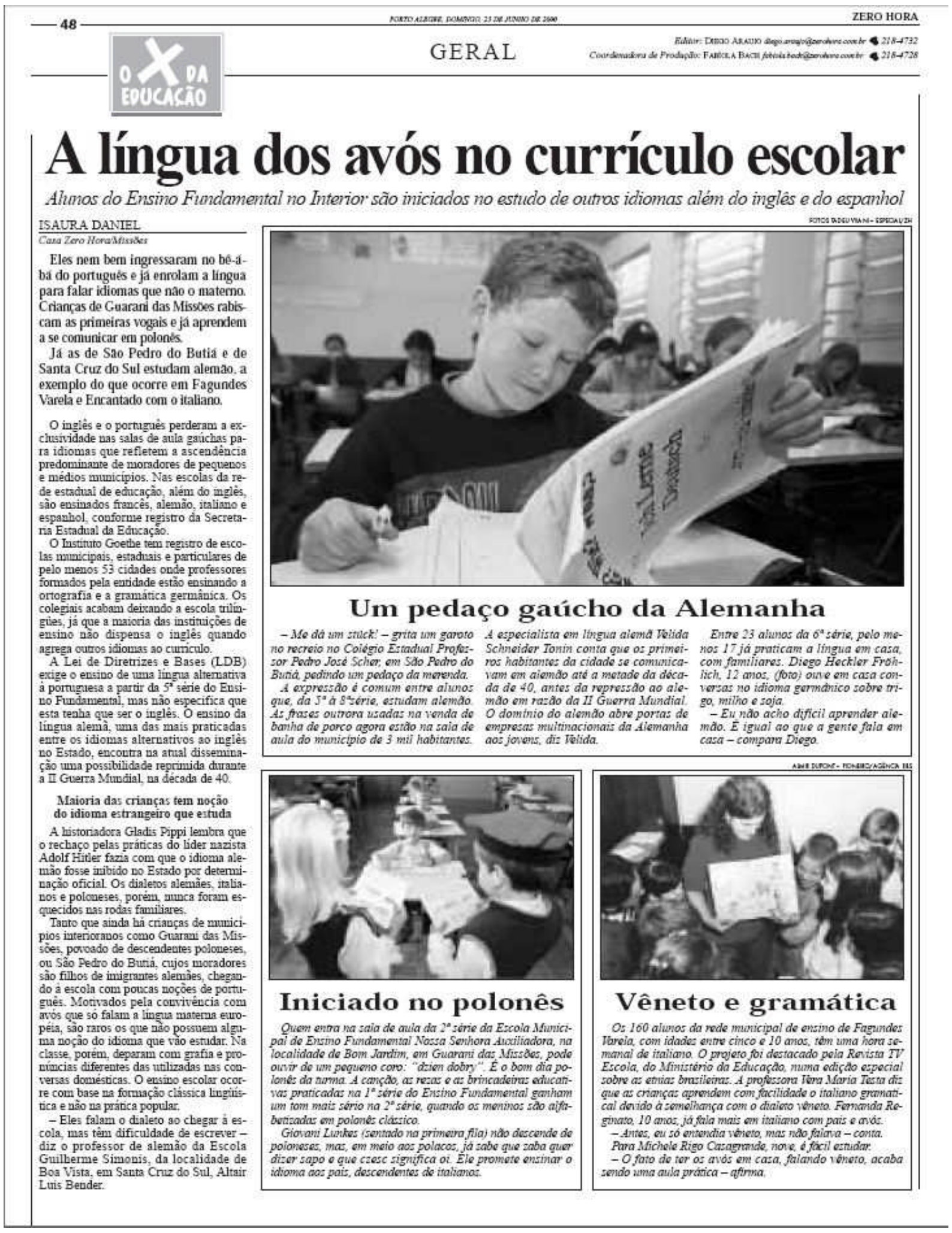



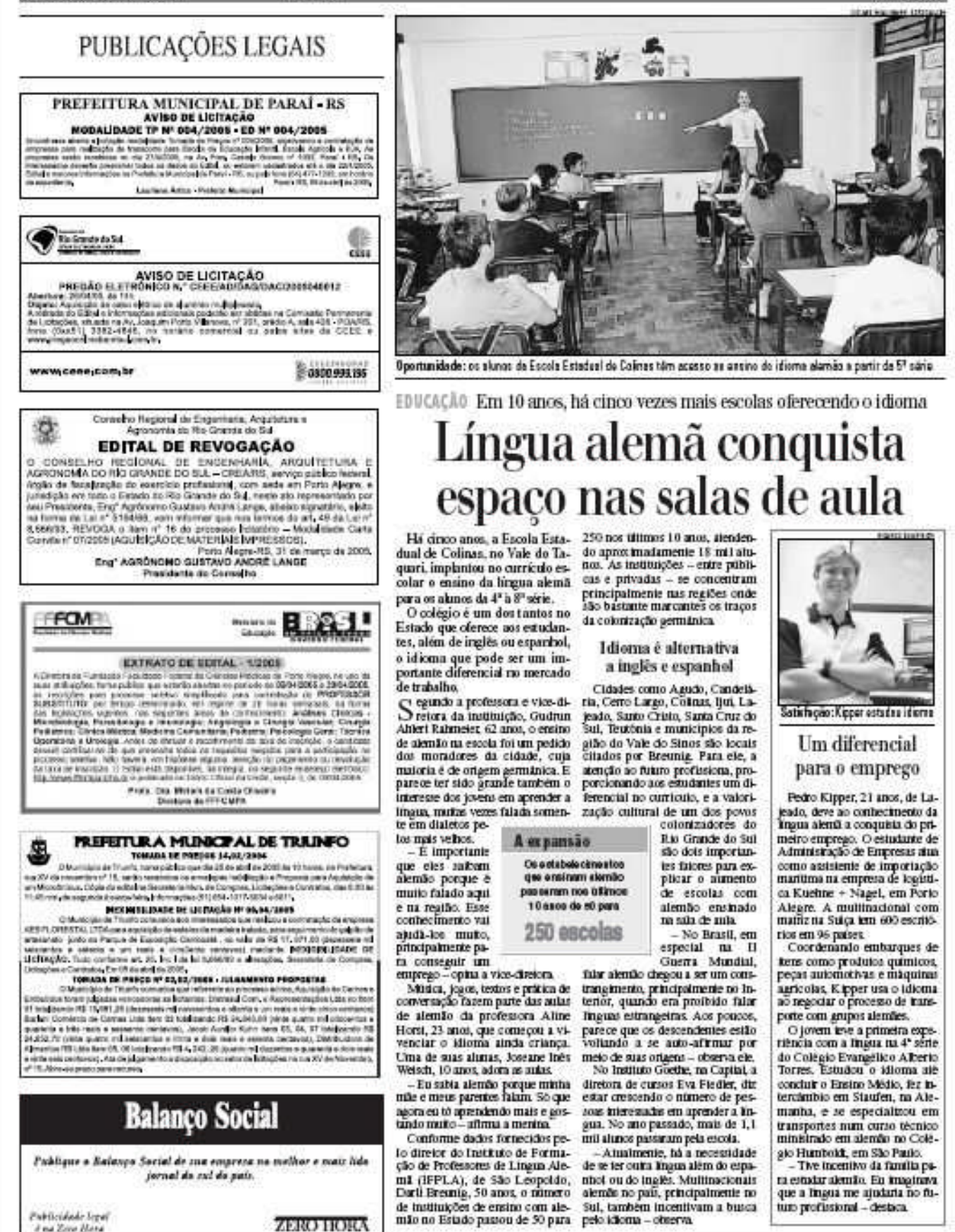

Evucaclo Em 10 anos, há cinoo vezes mais escolas oferecendo o idioms

\section{Língua alemã conquista espaço nas salas de aula}

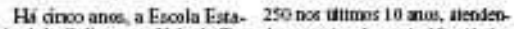
dual de Colinss, no Yake do Ta- do apmor mafamenie 18 mll alt quari. imptantoe no aurriculoes ad. As invades - se ocncentram

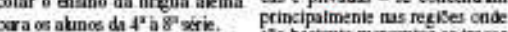
Oodejoe un dor tantos no 150 bastante marcantes os trapos

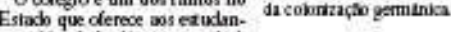
res, além de irgles ou esparhol, Idienra ê altentativa o idicma que pode ser um im- a ingles e espanhel portante diferencial no mercado a ingles e espanhisol
de trathilha

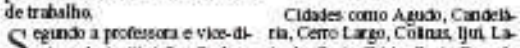

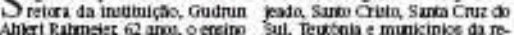

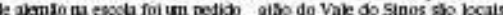

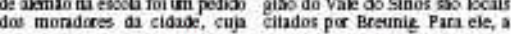

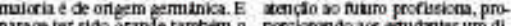

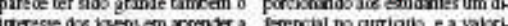

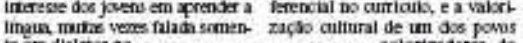

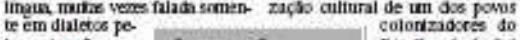

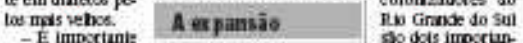

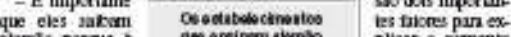
alistion o aumento 10aveo do so para

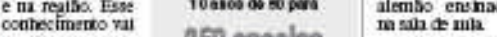

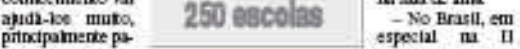
a conseguir im Guema sumdial,

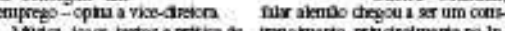

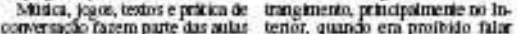

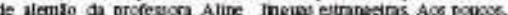

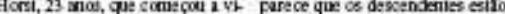

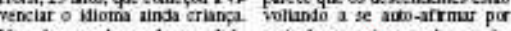

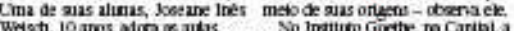

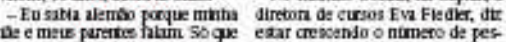

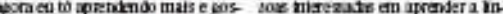

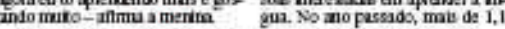

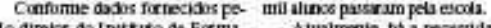

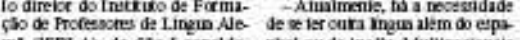

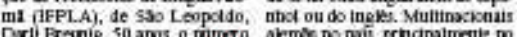

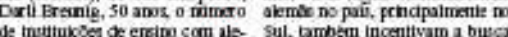

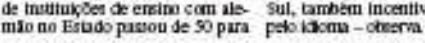

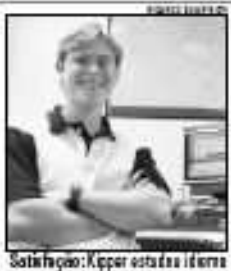

Im diferencial para 0 emprego Pedro Kipper, 21 ancs, de LA.

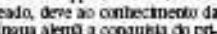
meiro emprezo. Oetin Afminisacso $\alpha$ Empreses atu ocmo assitiente of impociacto

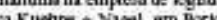
a kuatine + sapel, em Pori Alegre. A multimadonal com
matiz $1 \mathrm{ia}$ Sulca $\mathrm{km} 605$ escrib. tise em 95 praser
Cocrdenando embuques de tere como rrofubs quimicos

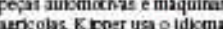
añcolas K Fper usa o ldikma porte com enjpos alemós. Ojorem we a primetra expe. riencis com a ingur tu $4^{*}$ torte do Colegis Evaneliko AReri: condur o Ereino Mesio, ter in

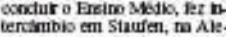
manhs, ese espedaitrou em uransportes num curso ternibo minkindo ent dembin no cak20 Humboit, em Sio Paiba

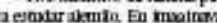

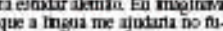
tuis prorisiond-areba

Data Publicaçăo : 06/04/2005

Edtorla : Gera:

liustraçăo : Foto

Aseunto:

Educaçà (cartola), Escol3, Sala de Aula, Ensino, Lingua Estrangeira 


\section{Alemão falado no Interior ganha dicionário}

MARCiele brum
U Venancio Ares
Uma lingüista alemã es-
tá organizando um dicio-
nário e pretende criar fo-
nemas para representar a
escrita do alemão falado
pelos descendentes germâ-
nicos no interior de Ve-
nâncio Aires, no Vale do
Rio Pardo.
A voluntária aposentada
anos, sustenta Wiesemann, 72
munidades se essas co-
com um alemanicam
sado. Diferentemente do
que se pensava, elas não
utilizam dialetos nem falam
de forma errada.
de forma errada.

O número de pessoas que

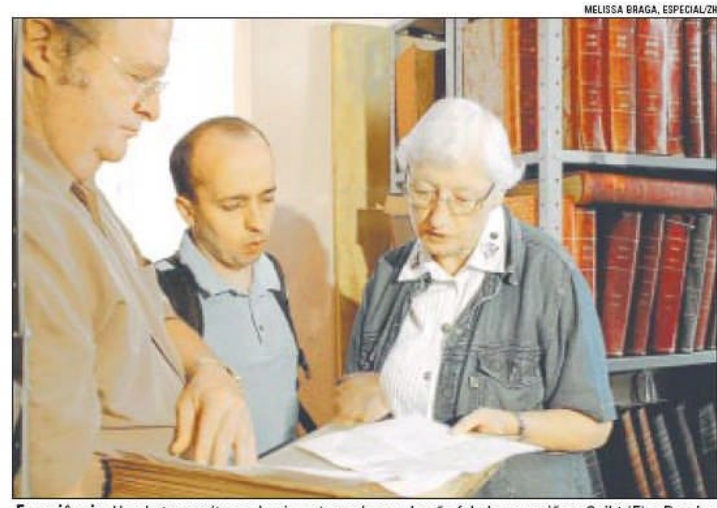

primeiro idioma que as têm desas aprendem. Elas falando errado - relata Bender.

A iniciativa partiu do Núcleo de Cultura de Venâncio Aires, que se inspirou no trabalho desenvolvido por Ursula em Santa Maria do Herval, na Serra, há um ano. No municipio de origens germânicas, 0 núcleo está fazendo um estudo sobre casas antigas, material histórico e potencial turistico.

- Vamos continuar as pesquisas também desse patrimônio imaterial (a lingua) nas duas cidades e incentivar a elaboração de mionario com a colamolific a comos inger mais de um século, ainda é desco- jeiras do Sul, no Paraná. Na Áfri- ver livros pedagógicos para dar- cleo Flávio Seibt.
molidente do numais de um seculo, ainda e desco-- jeiras do Sul, no Parana. Na Afri- ver livros pedagogicos para dar- cleo Flávio Seibt.
nhecido. Há registro de falantes na
ca, com a ajuda de um intérprete mos aulas aos agricultores e criar- A dirigente de cultura de Santa

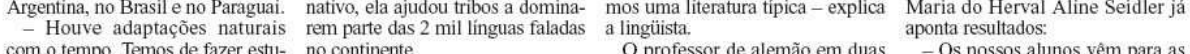
dos lingüísticos e ensinar a escrever o alemão que se inspira no português para que ele não se perca no continente.

Em Venâncio Aires, Ursula visi- O professor de alemão em duas - Os nossos alunos vêm para as tou o interior do município nesta semana e pretende orientar profes- rio a receber orientações da espe- demos a resgatar a cultura e a facisores voluntarios para difundir a cialista sobre a tarefa. - Temos de valorizar a língua do litar a aprendizagem do português. A professora interior, porque esse alemão é o
Mudam telefones com código 55

S telefones fixos - residenciais, comerciais e públicos da ăea do DDD 55 passarão a ter me

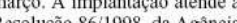
Nacional de Telecomunicações (Anatel).

A medida acrescentará o digito 3 na frente dos atuais números telefônicos de 96 municípios localizados nas regiōes da Fronteira Oeste, Central e Campanha do Estado, abrangendo cerca de 219 mil usuários.

A Brasil Telecom pretende utilizar avisos nas contas, mensagens telefonicas e anuncios em ornais e TV para orientar os usuários. No Estado, parte das regiões com DDD 51 e 55 já opera com o oitavo digito.

\section{Como ficará}

- Os números telefónicos que usam apenas sete digitos passaram a ter número 3 na frente - Por exemplo, o telefone 412 22XX, de Uruguaiana, passara a ser 3412-22XX A Brasil Telecom val apenas acrescentar o digito 3 à frente de todos os terminais telefônicos com sete digitios - A mudança está programada para 12 de março 